DOE/RL-2001-04

Rev. 0

\title{
Annual Summary Report Calendar Year 2000 for the 100-HR-3, 100-KR-4, and 100-NR-2 Operable Units and Pump-and-Treat Operations
}

United States

Department of Energy 
TRADEMARK DISCLAIMER

Reference herein to any specific commercial product,

process, or service by trade name, trademark, manufacturer, or otherwise, does not necessarily constitute or imply its endorsement, recommendation, or favoring by the United States Government or any agency thereof or its contractors or subcontractors.

This report has been reproduced from the best available copy.

Available in paper copy and microfiche.

Available for a processing fee to U.S. Department of Energy and its contractors from:

U.S. Department of Energy

Office of Scientific and Technical Information

P.O. Box 62

Oak Ridge, TN 37831-0062

(865) $576-8401$

fax: (865) 576-5728

email: reports@adonis.osti.gov

online ordering: http://www.doe.gov/bridge

Available for sale to the public, in paper, from:

U.S. Department of Commerce

National Technical Information Service

5285 Port Royal Road

Springfield, VA 22161

(800) 553-6847

fax: (703) 605.6900

email: orders@ntis.fedworld.gov

online ordering: http://www.ntis.gov/ordering.htm

Printed in the United States of America

DISCLM-5.CHP (11/99) 


\section{Annual Summary Report Calendar Year 2000 for the 100-HR-3, 100-KR-4, and 100-NR-2 Operable Units and Pump-and- Treat Operations}

August 2001

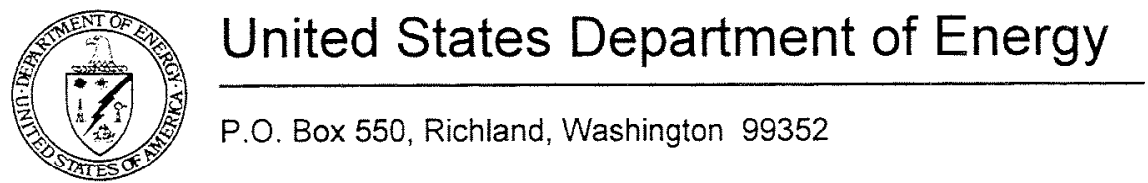




\section{EXECUTIVE SUMMARY}

\section{ES1.0 INTRODUCTION}

This annual progress and performance evaluation report discusses the groundwater remedial actions in the 100 Area, including the interim actions at the 100-HR-3 and 100-KR-4 Operable Units (OUs), and also discusses the expedited response action in the 100-NR-2 OU. Previously, 100-NR-2 pump-and-treat performance was reported with the 200-UP-1 and 200-ZP-1 pumpand-treat systems.

Pump-and-treat systems using an ion-exchange medium for contaminant removal were selected as the 100-HR-3 and 100-KR-4 OU interim remedial actions and as the expedited response action for the 100-NR-2 OU. The systems were designed to achieve the remedial action objectives (RAOs) as well as specific operational and aquifer performance criteria described in the interim remedial action Record of Decision for the 100-HR-3 and 100-KR-4 Operable Units at the Hanford Site Interim Remedial Actions (ROD) (EPA 1996) and in the N-Springs action memorandum (Ecology and EPA 1994). The 100-NR-2 system, as designed and operated, meets the RAOs described in the Interim Remedial Action Records of Decision for 100-NR-1 and 100NR-2 Operable Units (EPA 1999b).

In calendar year (CY) 2000, the U.S. Environmental Protection Agency (EPA) initiated a review of remedial actions at the Hanford Site in accordance with Comprehensive Environmental Response, Compensation, and Liability Act of 1980 (CERCLA) requirements. Several key items from the EPA 5-year review were directed specifically toward the 100 Area pump-and-treat operations (100-HR-3, 100-KR-4, and 100-NR-2):

- Optimize and complete system enhancements to the 100-HR-3 and 100-KR-4 groundwater pump-and-treat systems to run more reliably and achieve the required cleanup levels.

- The overall operational time of the system must improve.

- The downtime for individual wells must be dramatically reduced. 
- A much higher percentage of the targeted plume must be captured.

- Investigate alternative remedial action technologies for the removal, waste reduction, and/or attenuation of strontium-90 from the aquifer sediments in 100-NR-2 and to further reduce the net flux of strontium-90 to the river.

\section{ES2.0 100-HR-3 OPERABLE UNIT REMEDIAL ACTION OBJECTIVES}

Measurable progress was made toward meeting the specific RAOs for the 100-HR-3 OU

pump-and-treat interim action operation for the period of January 1, 2000, through December 31 , 2000. Each RAO is discussed below.

- RAO \#1: Protection of aquatic receptors in the river bottom substrate from contaminants in groundwater entering the Columbia River.

Result: Extraction wells in the 100-D and 100-H Areas are capturing a large portion of the chromium mass flux to the Columbia River and are thereby protecting aquatic receptors. This conclusion is based on the following field data, operational data, and groundwater monitoring results:

\section{0-D Area}

- During CY 2000, 135.7 million L of hexavalent chromium contaminated groundwater were treated and $25.3 \mathrm{~kg}$ removed.

- Numerical modeling suggests that the pump-and-treat captures approximately $84 \%$ of the ground flowing through the target areas. Capturing a high-concentration area located south of the target area will be evaluated as a part of the response to findings of the CERCLA 5-year review by the EPA.

- Average annual chromium concentrations in the 100-D Area compliance wells (199-D8-68, 199-D8-69, 199-D8-70) were higher than the average for the previous year and exceed the 
RAO of $22 \mu \mathrm{g} / \mathrm{L}$. These values were $195.8 \mu \mathrm{g} / \mathrm{L}$ and $191.4 \mu \mathrm{g} / \mathrm{L}$, respectfully. The short-term increase in concentrations may be attributed to lower river levels in the summer and fall of 2000 .

- Increasing chromium concentrations in a number of the northeastern plume perimeter wells in 2000 suggest that the extent of the chromium plume has expanded slightly.

- Co-contaminant data for strontium-90, tritium, nitrate, and sulfate indicate increasing trends when compared to previous results.

- No stratification or layering of chromium contamination was observed in CY 2000.

\section{0-H Area}

- During CY 2000, 169.4 million L of hexavalent chromium contaminated groundwater were treated and $4.7 \mathrm{~kg}$ removed.

- Numerical modeling suggests that the pump-and-treat system captures approximately $90 \%$ of the groundwater flowing through the target area.

- Average annual chromium concentrations in five 100-H Area compliance wells (199-H-4, 199-H-5, 199-H-63, 199-H-4, and 199-H-64) were higher than CY 1999 and exceed the RAO $(22 \mu \mathrm{g} / \mathrm{L})$. These values were $71.4 \mu \mathrm{g} / \mathrm{L}, 70.3 \mu \mathrm{g} / \mathrm{L}, 59.2 \mu \mathrm{g} / \mathrm{L}$, and $42.2 \mu \mathrm{g} / \mathrm{L}$, respectively. The short-term increase may be attributed to lower river stage.

- Of 31 monitoring wells sampled, trends were decreasing in 13 wells, trends were stable in 14 wells, and trends were increasing in 4 wells. The data suggest that highest chromium concentrations have been reduced and shifted closer to the extraction system.

- Co-contaminant data for strontium-90 and technetium-99 indicate decreasing versus stable trends. One well had an increasing tritium trend, and the other $100-\mathrm{H}$ wells were stable or 
decreasing. Extraction well 199-H4-12A had increasing uranium and nitrate trends, and co-contaminants were stable or decreasing in the other 100-H Area wells.

Overall, the distribution pattern and high-concentration areas for chromium have significantly diminished since CY 1998. This may be attributed to the effects of the remediation efforts at the 100-H Area.

- RAO \#2: Protection of human health by preventing exposure to contaminants in the groundwater.

Result: Institutional controls were maintained to prevent public access to groundwater.

- RAO \#3: Provide information that will lead to the final remedy.

Result: The following information will be used in determining the final remedy:

Treatment Cost: Treatment cost for the period was $\$ 2,202,500$. At a yearly production rate of 305 million $\mathrm{L}$ and $30 \mathrm{~kg}$ of chromium removed, the treatment cost equates to about $0.7 \phi / \mathrm{L}$, or $\$ 74 / \mathrm{g}$ of chromium removed.

System Efficiency: Removal efficiency of the treatment system was $93.4 \%$.

Hydraulic Impact: Numerical modeling was used to quantify the effectiveness of the capture and containment of the pump-and-treat system. The model suggests that the 100-D Area system captures groundwater from an estimated $84 \%$ of the targeted area that would otherwise discharge into the Columbia River. At the 100-H Area, the model suggests that the system captures groundwater from an estimated $86 \%$ of the targeted area that would otherwise discharge into the Columbia River. Capture at the 100-H Area increases to $94 \%$ when the new extraction well (199-H4-65) is on-line. 
Effectiveness of Contaminant Removal in Aquifer: During this reporting period, more than 305 million L of water was treated from the 100-HR-3 OU, which resulted in the removal of $30 \mathrm{~kg}$ of chromium. Since initiation of the system in July 1997, more than 959 million L of water has been treated, resulting in the removal of approximately $103.1 \mathrm{~kg}$ of chromium from the 100-HR-3 aquifer.

Maintain Data: Pertinent data have been maintained in the Hanford Environmental Information System database and in the project-specific database.

System Availability: Overall system availability for the reporting period exceeded $97 \%$, an increase from $89 \%$ in CY 1999. System availability is a ratio of the actual operating time to the total available operating time. Downtime includes scheduled and unscheduled maintenance; system modifications; and outages associated with weather, power loss, and other acts of nature.

\section{ES3.0 100-KR-4 OPERABLE UNIT REMEDIAL ACTION OBJECTIVES}

Measurable progress was made toward meeting the specific RAOs for the 100-KR-4 OU pumpand-treat interim action operation during the period from January 1, 2000, to December 31, 2000. Each of the RAOs is discussed below.

- RAO \#1: Protection of aquatic receptors in the river bottom substrate from contaminants in groundwater entering the Columbia River.

Result: Extraction wells in the 100-K Area are capturing chromium mass flux to the Columbia River and are thereby protecting aquatic receptors. This conclusion is based on field data, operational data, and groundwater modeling results:

- There were 286.7 million L of groundwater treated during CY 2000. 
- There were $33.5 \mathrm{~kg}$ of hexavalent chromium removed during CY 2000.

- Numerical modeling suggests that the pump-and-treat captures about $76 \%$ of the targeted plume. There is a gap in the capture zone between wells $199-\mathrm{K}-119 \mathrm{~A}$ and $199-\mathrm{K}-120 \mathrm{~A}$. To remedy this, a new extraction well will be installed in response to findings from the CERCLA 5-year review by the EPA.

- Average annual chromium concentrations in the 100-K Area compliance wells (199-K-18 [81.7 $\mu \mathrm{g} / \mathrm{L}], 199-\mathrm{K}-20$ [107.4 $\mu \mathrm{g} / \mathrm{L}], 199-\mathrm{K}-114 \mathrm{~A}[100.7 \mu \mathrm{g} / \mathrm{L}], 199-\mathrm{K}-117 \mathrm{~A}[44.2 \mu \mathrm{g} / \mathrm{L}]$, and $199-\mathrm{K}-126[83.9 \mu \mathrm{g} / \mathrm{L}])$ exceeded the RAO $(22 \mu \mathrm{g} / \mathrm{L})$. Three of the five wells (199-K-114A, 199-K-117A, and 199-K-126) showed an increase from the previous year.

- Chromium trends in monitoring wells were variable. Of the 14 wells monitored, 3 were increasing, 2 were decreasing, and the others were stable.

- Co-contaminant concentrations were variable. The strontium-90 trend in well 199-K-20 decreased, and the other 100-K Area wells were stable. Carbon-14 trends were stable or decreased. Nitrate concentrations increased in four wells and were stable or decreased in the other $100-\mathrm{K}$ wells.

- Average annual tritium concentrations increased in seven wells. Tritium concentrations are as high as $69,300 \mathrm{pCi} / \mathrm{L}( \pm 1,000)$ in well $199-\mathrm{K}-120 \mathrm{~A}$. In extraction well $199-\mathrm{K}-32 \mathrm{~A}$, tritium concentrations increased from 8,035 to $30,950 \mathrm{pCi} / \mathrm{L}$, which is above the drinking water standard of $20,000 \mathrm{pCi} / \mathrm{L}$. Tritium trends in other wells were stable or decreased.

- No stratification or layering of chromium contamination was observed in CY 2000.

- Overall, the chromium distribution pattern has remained constant, but the high-concentration areas are diminishing. This may be attributed to the remediation effort at the 100-K Area. 
- RAO \#2: Protection of human health by preventing exposure to contaminants in the groundwater.

Result: Institutional controls were maintained to prevent public access to groundwater.

- RAO \#3: Provide information that will lead to the final remedy.

Result: The following information will be used in determining the final remedy:

Treatment Cost: Treatment cost for the period was $\$ 1,383,000$. At a yearly production rate of 286.7 million $\mathrm{L}$ and $33.5 \mathrm{~kg}$ of chromium removed, the treatment cost equates to about $0.5 \phi / \mathrm{L}$, or $\$ 41 / \mathrm{g}$ of chromium removed.

System Efficiency: Removal efficiency of the treatment system exceeded $95 \%$.

Hydraulic Impact: Numerical modeling was used to quantify the effectiveness of the capture and containment of the pump-and-treat system. The model suggests that the 100-KR-4 system, with six extraction wells operating at or near their designed flow rates, captures groundwater from an estimated $76 \%$ of the targeted area that would otherwise discharge into the Columbia River. Optimizing the pumping rates and adding well $199-\mathrm{K}-112 \mathrm{~A}$ to the extraction well network increases the capture to about $86 \%$.

Effectiveness of Contaminant Removal in Aquifer: During this reporting period, approximately 286.7 million L of water were treated from the 100-KR-4 OU, which resulted in the removal of $33.5 \mathrm{~kg}$ of chromium. Since initiation of the system in October 1997, more than 908 million L of water have been treated, resulting in the removal of approximately $79 \mathrm{~kg}$ of chromium from the $100-\mathrm{KR}-4$ aquifer.

Maintain Data: Pertinent data have been maintained in the Hanford Environmental Information System database and in the project-specific database. 
System Availability: Overall system availability for the reporting period exceeded $98 \%$, which is the same as for CY 1999. System availability is a ratio of the actual time that the system is on-line to the total time available for operation. Downtime includes scheduled and unscheduled maintenance; system modifications; and outages associated with weather, power loss, and other acts of nature.

\section{ES4.0 100-NR-2 OPERABLE UNIT REMEDIAL ACTION OBJECTIVES}

Measurable progress was made toward meeting the RAOs for the 100-NR-2 OU. The status of the 100-NR-2 OU is presented in two subsections. The first subsection addresses conclusions regarding the RAOs, and the second addresses the OU monitoring for CY 2000.

\section{ES4.1 PROGRESS TOWARD REMEDIAL ACTION OBJECTIVES}

- Protect the Columbia River from adverse impacts from the 100-NR-2 groundwater so that designated beneficial uses of the Columbia River are maintained. Protect associated potential human and ecological receptors using the river from exposure to radioactive and nonradioactive contaminants present in the unconfined aquifer. Protection will be achieved by limiting exposure pathways, reducing or removing contaminant sources, controlling groundwater movement, or reducing concentrations of contaminants in the unconfined aquifer.

- Protect the unconfined aquifer by implementing remedial actions that reduce concentrations of radioactive and nonradioactive contaminants present in the unconfined aquifer.

Result: The pump-and-treat interim action continues to reduce the hydraulic gradient toward the river, thus inhibiting strontium-contaminated groundwater from entering the Columbia River. 
The capture area of the extraction wells, as determined from water-level measurements, nearly matches the area predicted in the performance evaluation report (DOE-RL 1996a). The pump-and-treat system is reducing net flux of groundwater by approximately $96 \%$ based on the comparison of measured data and previous modeling results. In addition, the pumpand-treat operation has removed a small amount of strontium-90 from the unconfined aquifer.

- Obtain information to evaluate technologies for strontium-90 removal and evaluate ecological receptor impacts from contaminated groundwater (by October 2004).

Result: Treatment options were evaluated in the $N$-Springs Pump-and-Treat System Optimization Study (DOE-RL 1997b). An average removal rate of greater than $90 \%$ was indicated for a 50-day cycle, or until 17 million $\mathrm{L}$ were treated using clinoptilolite as the treatment medium. The current operational cycle is 9.0 million $\mathrm{L}$ (approximately 30 days).

Over the past 3 years the Hanford Site 100-N Area Innovative Treatment and Remediation Demonstration (ITRD) has evaluated approximately 50 technologies for possible implementation at the site. Both in situ and ex situ technologies were reviewed. The evaluation process narrowed the field to five potentially useful technologies: natural attenuation, phytoremediation, clinoptilolite permeable barrier, sheetpile/cryogenic impermeable barrier, and soil flushing. Remediation of stronium-90 in the 100-N Area is in the final stages of being addressed by ITRD. A final report will be completed in December 2001.

Information provided in the performance evaluation report (DOE-RL 1996a) demonstrates the difficulty in removing strontium-90 from the aquifer sediments. Approximately $0.9 \mathrm{Ci}$ has been removed since startup (September 1995) versus an estimated 76 to $88 \mathrm{Ci}$ total inventory in groundwater and adsorbed on the saturated sediments (DOE-RL 1996a). Therefore, the pump-and-treat system does not appear to be an effective method for reducing strontium-90 concentrations in the aquifer. 
- Prevent destruction of sensitive wildlife habitat. Minimize the disruption of cultural resources and wildlife habitat in general and prevent adverse impacts to cultural resources and threatened or endangered species.

Result: Access to the Hanford Site, in general, and the N-Reactor Area in particular, is regulated by institutional controls. These controls minimize access to wildlife habitat and culturally sensitive sites.

\section{ES4.2 PUMP-AND-TREAT SYSTEM AND 100-NR-2 OPERABLE UNIT MONITORING}

Monitoring of the 100-NR-2 pump-and-treat system during CY 1999 resulted in the following data:

- Groundwater treated during CY 2000: 106 million L.

- Strontium-90 removed during CY 2000: $0.18 \mathrm{Ci}$.

- System availability: $96.6 \%$.

- Average percent removal: $90 \%$.

- The distribution pattern for strontium-90 contamination has not changed appreciably since fiscal year 1997.

- The distribution pattern for tritium contamination is similar to that described for the previous year. Concentrations are generally decreasing throughout the plume, with the highest remaining values less than $60,000 \mathrm{pCi} / \mathrm{L}$.

- No significant changes in chromium concentrations were observed during fiscal year 1999.

- Manganese concentrations in water samples from well 199-N-18, which has exhibited anomalously high values in the past, continue to be high $(5,320 \mu \mathrm{g} / \mathrm{L})$. 
- Nitrate shows both increasing trends and decreasing trends in 100-N Area wells.

- Sulfate is distributed in a plume (the primary source is the former 1324-N/NA Liquid Waste Disposal Facility). Concentrations are increasing in some 100-NR-2 wells and decreasing in others.

- Total petroleum hydrocarbons (dissolved) continue to be observed in only one well, 199-N-18. The concentration in September 2000 was $23 \mathrm{mg} / \mathrm{L}$, a decrease from the 1999 value of $34 \mathrm{mg} / \mathrm{L}$. 


\section{TABLE OF CONTENTS}

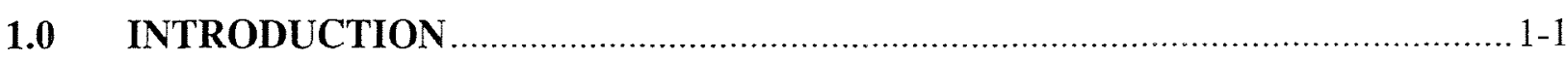

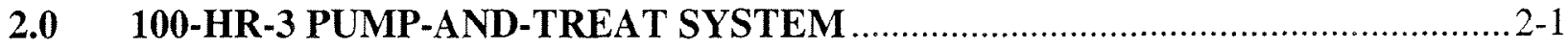

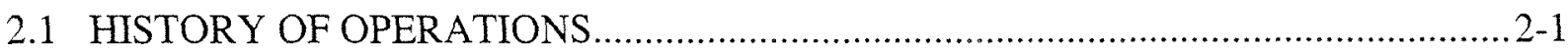

\subsection{TREATMENT SYSTEM PERFORMANCE2-3}

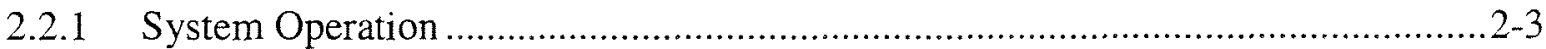

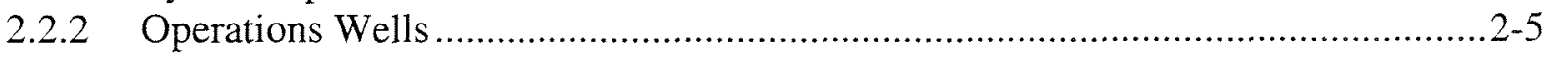

2.2.3 Operational Monitoring and Sampling ..................................................... 2-5

2.3 AQUIFER RESPONSE IN THE 100-D AREA ............................................ 2-7

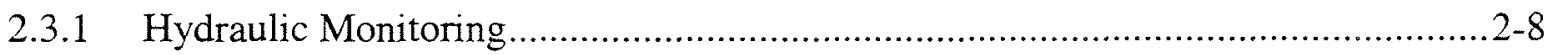

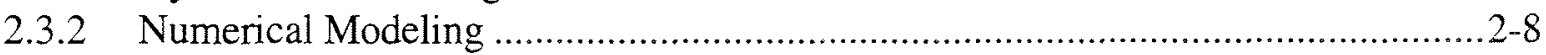

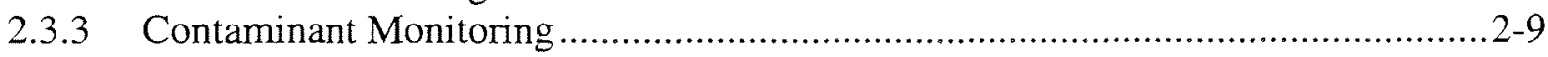

2.4 AQUIFER RESPONSE IN THE 100-H AREA ...........................................2-14

2.4.1 Hydraulic Monitoring ............................................................................ 2-14

2.4.2 Numerical Modeling .............................................................................. 2-15

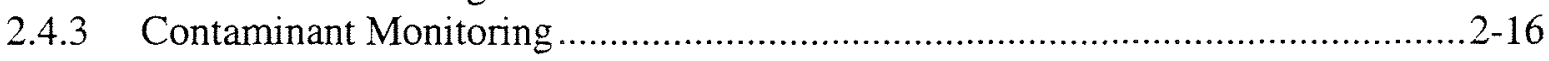

2.5 Quality Assurance/Quality Control for 100-D and 100-H Monitoring Data ...............2-20

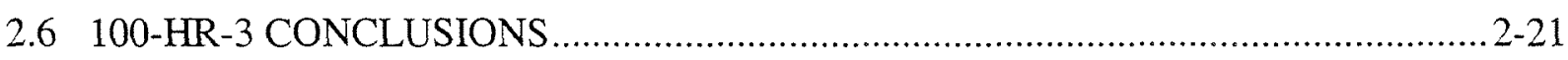

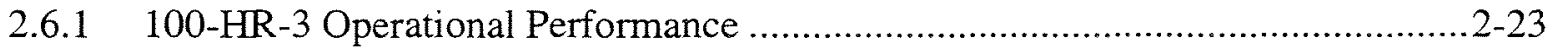

2.6.2 100-HR-3 Aquifer Performance...........................................................2-23

2.7 ISSUES FOR FURTHER EVALUATION AT THE 100-HR-3 OU ........................2-23

2.8 RECOMMENDATIONS FOR THE 100-HR-3 OU SYSTEM ...............................2-24

$3.0 \quad 100-K R-4$ PUMP-AND-TREAT SYSTEM ................................................ $3-1$

3.1 HISTORY OF OPERATIONS ....................................................................... $3-1$

3.2 100-KR-4 TREATMENT SYSTEM PERFORMANCE ............................................ 3-2

3.2.1 System Operation ................................................................................... $3-2$

3.2.2 Operations Wells .................................................................................... 
3.2.3 Operational Monitoring/Sampling $3-4$

3.2.4 Hexavalent Chromium in Extraction Wells 3-5

3.3 AQUIFER RESPONSE IN THE 100-K AREA 3-6

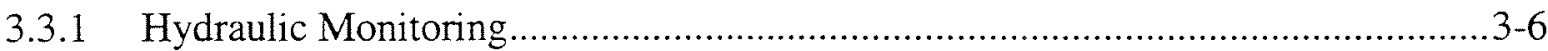

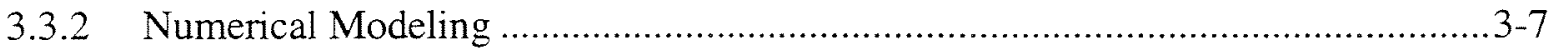

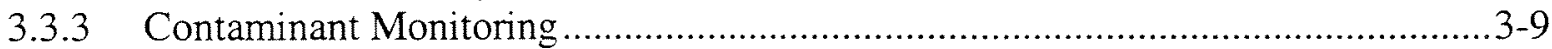

3.4 Quality Assurance/Quality Control for 100-K Monitoring Data ................................. 3-13

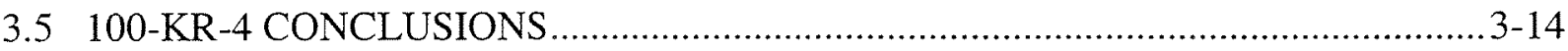

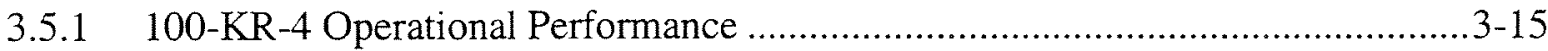

3.5.2 100-KR-4 Aquifer Performance ............................................................. $3-16$

3.6 ISSUES THAT NEED FURTHER EVALUATION AT THE 100-KR-04 OU ............3-16

3.7 Recommendations for the 100-KR-4 OU System.................................................

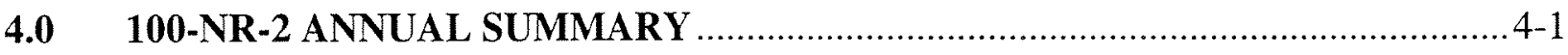

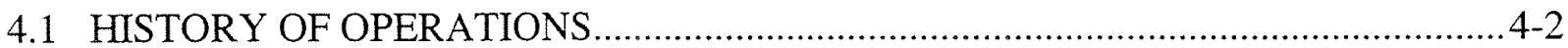

4.2 TREATMENT SYSTEM PERFORMANCE ................................................ $4-3$

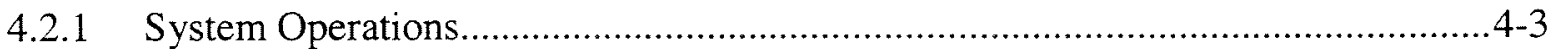

4.2.2 Operations Wells .....................................................................................4-4

4.2.3 Operational Sampling............................................................................

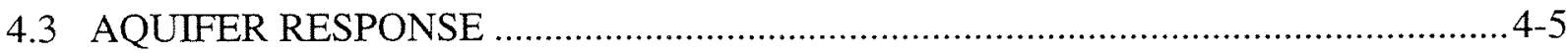

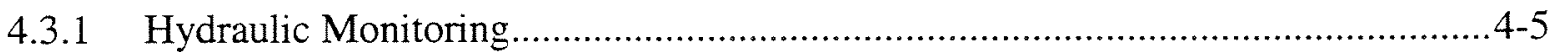

4.3.2 Numerical Modeling .............................................................................. $4-6$

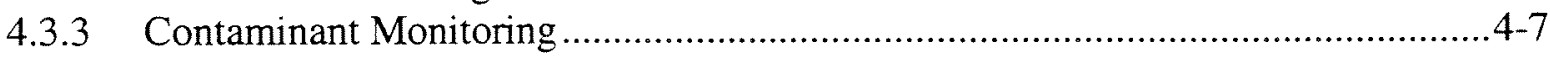

4.4 Quality Assurance/Quality Control for 100-NR-2 Monitoring Data .......................... 4-11

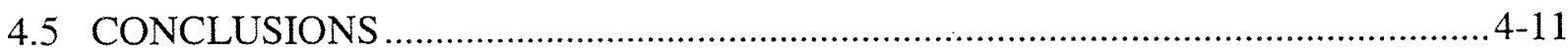

4.5.1 Progress Toward Remedial Action Objectives (RAOs) ..................................4-11

4.5.2 Pump-and-Treat System and 100-NR-2 Operable Unit Monitoring....................4-12

4.6 ISSUES THAT NEED FURTHER EVALUATION AT THE 100-NR-2 OU............4-13

5.0 PUMP-AND-TREAT SYSTEM COST DATA …....................................... $5-1$ 
5.1 100-HR-3 PUMP-AND-TREAT SYSTEM COSTS …............................................ 5-1

5.2 100-KR-4 PUMP-AND-TREAT SYSTEM COSTS …............................................ $5-2$

$5.3100-N R-2$ PUMP-AND-TREAT SYSTEM COSTS ........................................... $5-2$

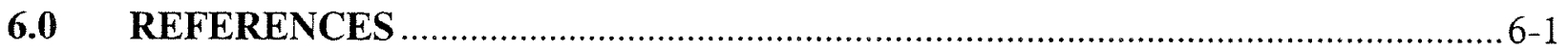

\section{APPENDICES}

A CONTAMINANT TREND PLOTS FOR 100-HR-3 EXTRACTION WELLS............. A-i

B 100-HR-3 HYDROGRAPHS AND DRAWDOWN ANALYSIS .............................. B-i

C 100-KR-4 HYDROGRAPHS AND DRAWDOWN ANALYSIS ............................... C-i

D 100-HR-3 CONTAMINANT TREND PLOTS FOR THE 100-D AREA WELLS ........ D-i

E 100 AREA SAMPLING AND ANALYSIS MATRIX …......................................... E-i

F 100-HR-3 CONTAMINANT TREND PLOTS FOR THE 100-H AREA WELLS .......... $-\mathrm{i}$

G CONTAMINANT TREND PLOTS FOR 100-KR-4 EXTRACTION WELLS.............. G-i

$\mathrm{H} \quad 100-\mathrm{KR}-4$ CONTAMINANT TREND PLOTS FOR THE 100-K AREA WELLS ........ H-i

I 100-NR-2 HYDROGRAPHS AND DRAWDOWN ANALYSIS ................................ I-i

$\mathrm{J}$ 100-NR-2 CONTAMINANT TREND PLOTS FOR THE 100-N AREA WELLS ......... J-i

$\mathrm{K}$ ASSUMPTIONS, DEVELOPMENT, AND LIMITATIONS OF THE

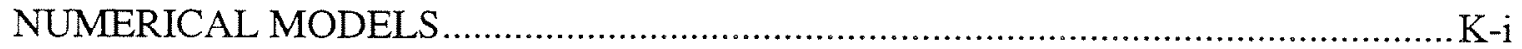

\section{FIGURES:}

1-1. 100 Area Project Locations. ............................................................................... 1-3

2-1. 100-HR-3 Operable Unit Pump-and-Treat System Layout.......................................... 2-25

2-2. 100-HR-3 Operable Unit, 100-D Area Layout of Well and Aquifer Sampling Tubes......................................................................................... 2-26

2-3. 100-HR-3 Operable Unit, 100-H Area Layout of Well and Aquifer Sampling Tubes............................................................................................... 2-27

2-4. 100-HR-3 Operable Unit Pump-and-Treat System Schematic. ...................................2-28

2-5. 100-HR-3 Trends of Influent and Effluent Hexavalent Chromium Concentrations...... 2-29

2-6. 100-HR-3 Pump-and-Treat Trends of Average Removal Efficiencies.........................2-30

2-7. 100-HR-3 System Availability and On-Line Percentages. ........................................2-31

2-8. 100-HR-3 Hexavalent Chromium Concentrations Comparison of Technician Versus Operator Data and the Relative Percent Difference.......................................2-32

2-9. Evaluation of 100-HR-3 (100-D Area) Hydraulic Capture Using Water Particle

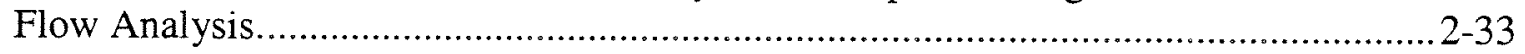

2-10. Estimated Steady-State Hydraulic Capture Zone Development by 100-HR-3 Operable Unit 100-D Area Extraction Wells...........................................................2-34

2-11. 100-D Area Historic Chromium Distribution. ........................................................2. 2-35

2-12. 100-HR-3 (100-D Area) Hexavalent Chromium Plume and Trend Plots......................2-37 
2-13. Estimated Steady-State Hydraulic Capture Zone Developed by $100-H R-3$ Operable Unit 100-H Area Extraction Wells. .........................................................2 2-39

2-14. Evaluation of 100-HR-3 (100-H Area) Hydraulic Capture Using Water Particle

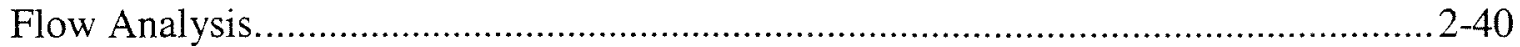

2-15. 100-H Area Historic Chromium Distribution. ........................................................2 $2-41$

2-16. 100-HR-3 (100-H Area) Hexavalent Chromium Plume and Trend Plots.................... 2-43

3-1. 100-KR-4 Operable Unit Pump-and-Treat System Location.................................... 3-17

3-2. 100-KR-4 Operable Unit Layout of Wells and Aquifer Sampling Tubes....................3-18

3-3. 100-KR-4 Operable Unit Pump-and-Treat System Schematic. ...................................3-19

3-4. 100-KR-4 Pump-and-Treat Trends of Influent and Effluent Hexavalent

Chromium Concentrations for Calendar Year 2000 ...........................................3-20

3-5. 100-KR-4 Pump-and-Treat Trends of Average Removal Efficiencies.......................3-21

3-6. 100-KR-4 System Availability and On-Line Percentages. ................................... 3-22

3-7. 100-KR-4 Hexavalent Chromium Concentration Comparison of Technician Versus Operator Data and Relative Percent Difference.......................................... 3-23

3-8. Estimated Steady-State Hydraulic Capture Zone Developed by $100-K R-4$ Operable Unit Extraction Wells..................................................................... 3-24

3-9. Evaluation of 100-KR-4 Hydraulic Capture Using Water Particle Flow Analysis........3-25

3-10. Evaluation of 100-KR-4 Hydraulic Capture Using Water Particle Flow Analysis with Revised Pumping Schedule............................................................................ 3-26

3-11. 100-K Area Historic Chromium Distribution. .............................................. 3-27

3-12. 100-KR-4 Hexavalent Chromium Plume and Trend Plots .........................................3-29

4-1. General Layout of the 100-NR-2 Pump-and-Treat System and Well Locations..........4-14

4-2. N-Springs Pump-and-Treat Process Flow Diagram................................................... 4-15

4-3. System Availability for the 100-NR-2 Pump-and-Treat System, Fourth Quarter

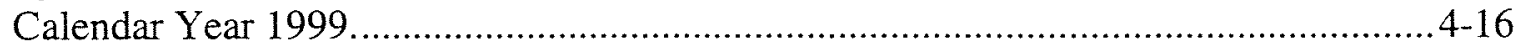

4-4. System Availability for the 100-NR-2 Pump and Treat System, CY 2000................4-17

4-5. 100-NR-2 Pump-and-Treat Trends of Influent and Effluent Strontium-90 Activities, September 1995-December 2000 ......................................................................4-18

4-6. Comparison of November 2000 Modeled Capture Flow Lines to DOE-RL (1996a) Modeled Capture Flow Lines............................................................................4-19

4-7. Comparison of November 2000 Modeled Capture Flow Lines to DOE-RL (2000c) Estimated Capture Flow Lines. ............................................................................. 4-20

4-8. 100-N Area Historic Strontium-90 Distribution. ......................................................4-21

4-9. 100-NR-2 Strontium-90 Plume and Trend Plots......................................................4-23

4-10. 100-NR-2 (100-N Area) Fall 2000 Tritium Plume. .................................................. 4-25

4-11. 100-NR-2 (100-N Area) Fall 2000 Sulfate Plume. ............................................. 4-26

5-1. Cost Breakdown for 100-HR-3 Pump-and-Treat Construction and Operations............ 5-3

5-2. Cost Breakdown for 100-KR-4 Pump-and-Treat Construction and Operations............. 5-4

5-3. Cost Breakdown for 100-NR-2 Pump-and-Treat Construction and Operations..............5-5 


\section{TABLES}

2-1. 100-HR-3 Pump-and-Treat Summary of Operations for Calendar Year 2000............ 2-45

2-2. 100-HR-3 Extraction Well Chromium Concentrations..............................................2-45

2-3. 100-HR-3 Technician's Duplicate Chromium Results. ............................................2-46

2-4. 100-HR-3 Quarterly Chromium Sampling and Operations Data Comparison ............2-46

2-5. 100-HR-3 Field and Analytical Laboratory Splits.............................................2-47

2-6. 100-HR-3 Co-Contaminant Concentrations in Extraction Wells...............................2-47

2-7. 100-HR-3 (100-D Area) Water-Level Data and Results of the Drawdown/Buildup Analysis Used to Develop and Calibrate Numerical Groundwater Flow Models. ........ 2-50

2-8. CY 2000 Groundwater Monitoring Network and Sampling Frequencies

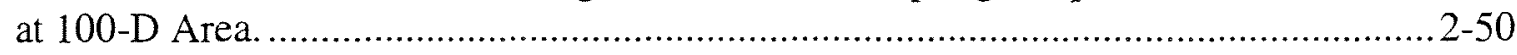

2-9. Construction Details and Use of Each 100-D Area Well........................................2 2-51

2-10. Selected Chromium Data for 100-D Area Wells. ...................................................2-53

2-11. 100-D Area Co-Contaminant Summary...............................................................2 2-54

2-12. 100-HR-3 (100-H Area) Water-Level Data and Results of the Drawdown/Buildup Analysis Used to Develop and Calibrate Numerical Groundwater Flow Models. ........2-56

2-13. CY 2000 Groundwater Monitoring Network and Sampling Frequency

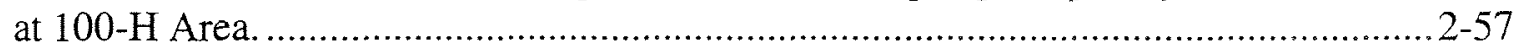

2-14. Construction Details and Use of Each of the 100-H Area Wells..............................2-57

2-15. Summary of Hexavalent Chromium Concentrations and Trends Within the 100-H Area Wells............................................................................................ 2-59

2-16. 100-H Area Co-Contaminant Summary...............................................................2-60

2-17. Quality Control Results, 100-D and 100-H Area................................................2-63

2-18. Operational Performance Summary for the 100-HR-3 Pump-and-Treat System. ........2-64

2-19. Aquifer Performance Summary for the 100-HR-3 Pump-and-Treat System...............2-66

3-1. 100-KR-4 Pump and-Treat Summary of Operations for Calendar Year 2000.............3-31

3-2. 100-KR-4 Extraction Well Chromium Concentrations............................................. 3-31

3-3. 100-KR-4 Technicians Duplicate Results for Chromium..........................................3-32

3-4. 100-KR-4 Quarterly Chromium Sampling and Operations Data Comparison. .............3-32

3-5. 100-KR-4 Field and Analytical Laboratory Chromium Splits...................................3-33

3-6. 100-KR-4 Co-Contaminant Concentrations in Extraction Wells.................................3-33

3-7. 100-KR-4 Water-Level Data and Results of the Drawdown/Buildup Analysis Used to Develop and Calibrate Numerical Groundwater Flow Models. ......................3-34

3-8. CY 2000 Groundwater Monitoring Network and Sampling Frequency at

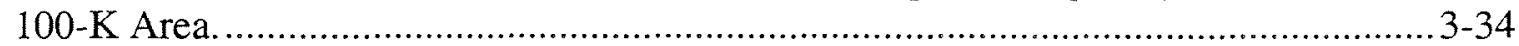

3-9. Construction Details and Use of Each 100-K Area Well ...........................................3-35

3-10. Summary of Hexavalent Chromium Concentrations and Trends Within

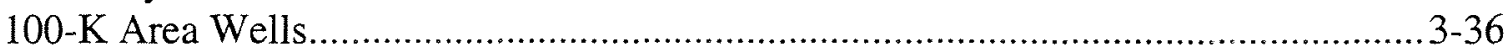

3-11. 100-K Area Co-Contaminant Summary ................................................................ 3-37

3-12. Quality Control Results, 100-K Area .................................................................... 3-39

3-13. Operational Performance Summary for the 100-KR-4 Pump-and-Treat System.........3-41

3-14. Aquifer Performance Summary for the 100-KR-4 Pump-and-Treat System............... 3-42

4-1. Volume of Groundwater Treated and Strontium Removed Since Startup of Operations at 100-NR-2. 
4-2. Average Strontium-90 Activities for Influent and Effluent Tanks at the 100-NR-2 Pump-and-Treat System.

4-3. 100-NR-2 Water-Level Data and Results of the Drawdown/Buildup Analysis Used to Develop and Calibrate Numerical Groundwater Flow Models. 4-28

4-4. Construction Details and Use of Each 100-NR-2 Area Well...................................4-28

4-5. 100-N Area Strontium-90 Summary............................................................... 4-30

4-6. 100-N Area Contaminants of Concern Summary....................................................4-31

4-7. Quality Assurance/Quality Control for 100-NR-2 Monitoring Data. ........................ 4-35 


\section{ACRONYMS}

CERCLA Comprehensive Environmental Response, Compensation, and Liability Act of 1980

COC contaminant of concern

$\mathrm{CY}$

calendar year

DOE

U.S. Department of Energy

Ecology

Washington State Department of Ecology

EPA

ERA

U.S. Environmental Protection Agency

FY expedited response action

HEIS

fiscal year

IRM

ISRM

Hanford Environmental Information System

interim remedial measure

ITRD

IX

In Situ Redox Manipulation

Innovative Treatment and Remediation Demonstration

MCL

ion exchange

maximum contaminant limit

$\mathrm{OIC}$

OU

PLC

operator-interface computer

operable unit

PNNL

programmable logic controller

QA

QC

$\mathrm{RAO}$

RCRA

Pacific Northwest National Laboratory

ROD

quality assurance

quality control

remedial action objective

RPD

Resource Conservation and Recovery Act of 1976

Record of Decision

RUM

relative percent difference

Ringold Upper Mud Unit 


\section{METRIC CONVERSION CHART}

\begin{tabular}{|c|c|c|c|c|c|}
\hline \multicolumn{3}{|c|}{ Into Metric Units } & \multicolumn{3}{|c|}{ Out of Metric Units } \\
\hline If You Know & Multiply By & To Get & If You Know & Multiply By & To Get \\
\hline Length & & & Length & & \\
\hline inches & 25.4 & millimeters & millimeters & 0.039 & inches \\
\hline inches & 2.54 & centimeters & centimeters & 0.394 & inches \\
\hline feet & 0.305 & meters & meters & 3.281 & feet \\
\hline yards & 0.914 & meters & meters & 1.094 & yards \\
\hline miles & 1.609 & kilometers & kilometers & 0.621 & miles \\
\hline Area & & & Area & & \\
\hline sq. inches & 6.452 & sq. centimeters & sq. centimeters & 0.155 & sq. inches \\
\hline sq. feet & 0.093 & sq. meters & sq. meters & 10.76 & sq. feet \\
\hline sq. yards & 0.836 & sq. meters & sq. meters & 1.196 & sq. yards \\
\hline sq. miles & 2.6 & sq. kilometers & sq. kilometers & 0.4 & sq. miles \\
\hline acres & 0.405 & hectares & hectares & 2.47 & acres \\
\hline Mass (weight) & & & Mass (weight) & & \\
\hline ounces & 28.35 & grams & grams & 0.035 & ounces \\
\hline pounds & 0.454 & kilograms & kilograms & 2.205 & pounds \\
\hline ton & 0.907 & metric ton & metric ton & 1.102 & ton \\
\hline Volume & & & Volume & & \\
\hline teaspoons & 5 & milliliters & milliliters & 0.033 & fluid ounces \\
\hline tablespoons & 15 & milliliters & liters & 2.1 & pints \\
\hline fluid ounces & 30 & milliliters & liters & 1.057 & quarts \\
\hline cups & 0.24 & liters & liters & 0.264 & gallons \\
\hline pints & 0.47 & liters & cubic meters & 35.315 & cubic feet \\
\hline quarts & 0.95 & liters & cubic meters & 1.308 & cubic yards \\
\hline gallons & 3.8 & liters & & & \\
\hline cubic feet & 0.028 & cubic meters & & & \\
\hline cubic yards & 0.765 & cubic meters & & & \\
\hline Temperature & & & Temperature & & \\
\hline Fahrenheit & $\begin{array}{l}\text { subtract } 32 \text {, } \\
\text { then } \\
\text { multiply by } \\
5 / 9\end{array}$ & Celsius & Celsius & $\begin{array}{l}\text { multiply by } \\
9 / 5, \text { then add } \\
32\end{array}$ & Fahrenheit \\
\hline Radioactivity & & & Radioactivity & & \\
\hline picocuries & 37 & millibecquerel & millibecquerels & 0.027 & picocuries \\
\hline
\end{tabular}




\subsection{INTRODUCTION}

The Environmental Restoration Contractor conducts groundwater remediation activities across the Hanford Site for the U.S. Department of Energy (DOE). Operable units (OUs), as defined under the Comprehensive Environmental Response, Compensation, and Liability Act of 1980 (CERCLA), have been established to address groundwater contamination issues in various areas of the Hanford Site. Groundwater has been contaminated by a variety of chemical and radiological constituents associated with past liquid effluent disposal, as well as unintentional leaks and spills.

The Environmental Restoration Contractor is currently operating five groundwater pump-and-treat systems across the Hanford Site. Three systems are remediating groundwater in the 100 Areas: one system with two sites for the 100-HR-3 OU (treating hexavalent chromium), one system for the 100-KR-4 OU (treating hexavalent chromium), and one system for the 100 NR-2 OU (treating strontium-90). Two pump-and-treat systems address groundwater contamination in the 200 West Area: one system for the 200-UP-1 OU (treating technetium-99, uranium, carbon tetrachloride, and nitrate), and another system for the 200-ZP-1 OU (treating carbon tetrachloride, chloroform, and trichloroethylene).

The annual progress and performance evaluation report discusses the groundwater remedial action in the 100 Area, including the interim actions at the 100-HR-3 and 100-KR-4, and 100-NR-2 OUs (Figure 1-1). Previously, 100-NR-2 pump-and-treat performance was reported with the 200-UP-1 and 200-ZP-1 pump-and-treat systems. The 100-HR-3 and 100-KR-4 pumpand-treat performance has been reported on a calendar year (CY) basis, while 100-NR-2 pumpand-treat performance was formerly reported on a fiscal year (FY) basis. Because this report is combining all 100 Area pump and treats, all performance will be reported in terms of CY 2000 progress. In addition, the fourth quarter of CY 1999 is included for the 100-NR-2 OU, as those performance statistics have never appearcd in an annual report.

The interim remedial actions selected for the 100-HR-3 and 100-KR-4 OUs are pump-and-treat systems that use an ion-exchange (IX) medium for contaminant removal. The systems were designed to achieve three remedial action objectives (RAOs), as well as specific operational and aquifer performance criteria described in the interim remedial action Record of Decision (ROD) (EPA 1996). The three RAOs are identified below:

- $\mathrm{RAO} \# 1$ : Protection of aquatic receptors in the river bottom substrate from contaminants in groundwater entering the Columbia River.

- RAO \#2: Protection of human health by preventing exposure to contaminants in the groundwater.

- RAO \#3: Provide information that will lead to the final remedy.

The interim remedial action ROD for the 100-NR-1 and 100-NR-2 OUs specifies the selected remedy and activities for the 100-NR-2 OU (Ecology 1999). Some of these activities are 
ongoing actions as a result of the action memorandum (e.g., operation of the pump-and-treat system and monitoring wells for contaminants of concern [COCs]). These activities and their reporting requirements will be described in the remedial design/remedial action work plan, as required by the 100-NR-1/100-NR-2 ROD (Ecology 1999). The RAOs are as follows:

- Reduce strontium-90 contaminant flux from the groundwater to the Columbia River

- Evaluate commercially available treatment options for strontium-90

- Provide data necessary to set demonstrable strontium-90 groundwater cleanup standards.

This report discusses progress towards meeting the RAOs and the ERA goals, as well as meeting specific operational and aquifer performance criteria for the 100-HR-3, 100-KR-4, and 100-NR-2 pump-and-treat systems. Additional discussion is provided about other contaminants in the OUs not addressed by the pump-and-treat remediation systems.

The purpose of this annual report is to support the following information needs:

- Document groundwater remediation system performance and status

- Document general aquifer conditions and response to remedial actions

- Provide discussion on remediation efforts.

This report is organized into three main sections, each presenting the annual summary and performance evaluation for the three respective OUs. Section 2.0 discusses the $100-\mathrm{HR}-3 \mathrm{OU}$, Section 3.0 discusses the 100-KR-4 OU, and Section 4.0 discusses the 100-NR-2 OU. Within each of these main sections, the following topics are discussed:

- Overview and history of each OU

- Summary of treatment system operations

- Summary and analysis of aquifer and contaminant monitoring

- Conclusions and recommendations.

An evaluation of costs required to operate the systems is provided in Section 5.0. Supporting information is contained in Appendices A through $\mathrm{H}$. 
Figure 1-1. 100 Area Project Locations.
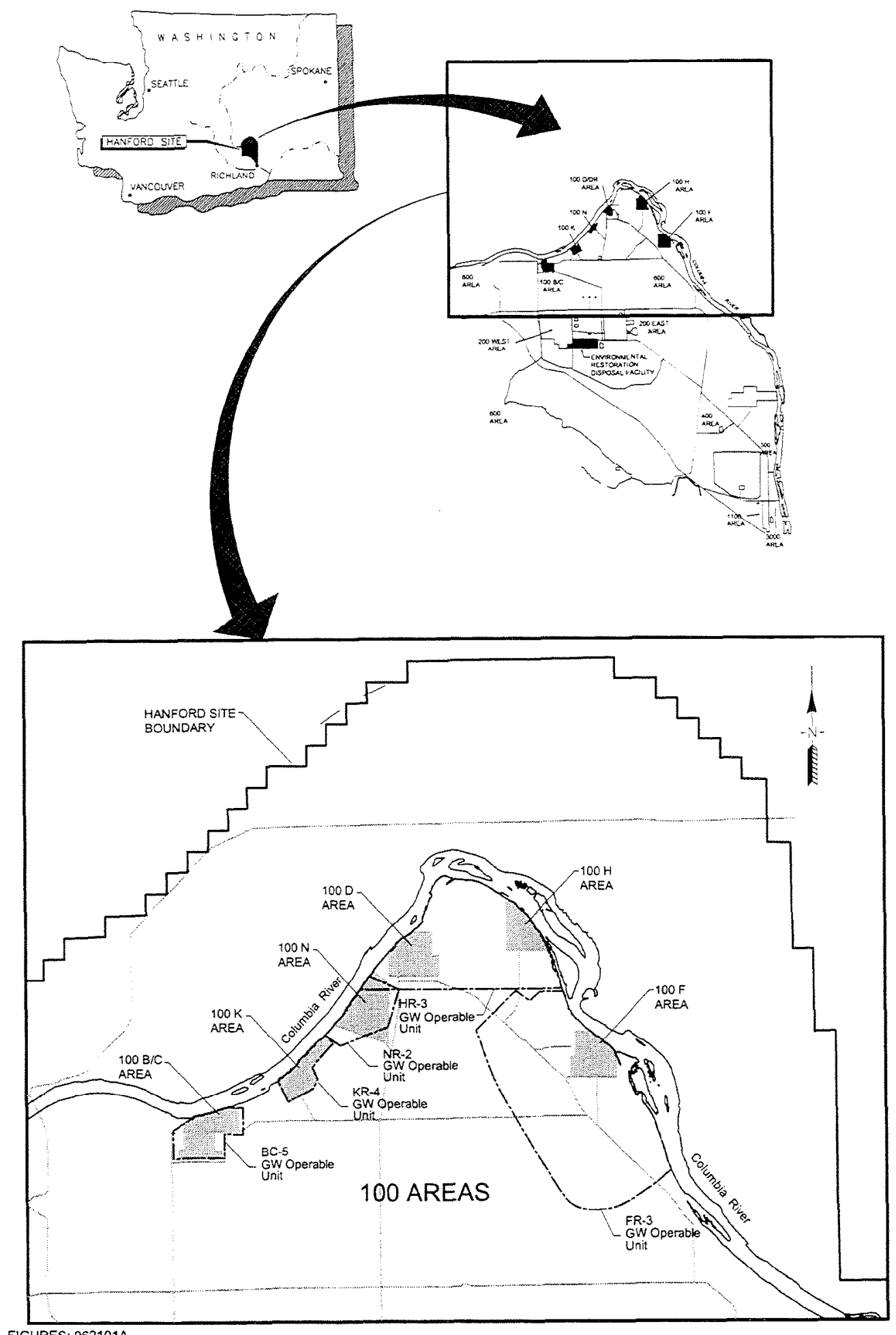

CYOO Annual Summary Report for the 100-HR-3, 100-KR-4, \& 100-NR-2 OU \& P\&T Operations 


\subsection{0-HR-3 PUMP-AND-TREAT SYSTEM}

The 100-HR-3 pump-and-treat facility is located in the north-central part of the Hanford Site along the Columbia River. The 100-HR-3 OU represents the groundwater underlying the source OUs that is associated with the 100-D and 100-H Reactor areas and the adjacent 600 Area (Figure 2-1). Groundwater extraction systems have been installed at both the 100-D and $100-\mathrm{H}$ Reactor areas, with a common treatment facility in a surplus building located near the 100-H Reactor. The well locations for the 100-D Area are shown in Figure 2-2, and the 100-H Area well locations are shown in Figure 2-3. Treated groundwater is returned to the aquifer via injection wells, which are located in the 100-H Area, upgradient of the extraction well fields.

This section provides the annual summary report for the 100-HR-3 OU for the reporting period of January 1, 2000, through December 31, 2000. The section is arranged in seven subsections. Section 2.1 presents the history of operations, provides references to applicable documents, and briefly discusses other relevant activities. Section 2.2 summarizes the treatment system performance, system operations, injection/extraction well operations, and operational sampling. An evaluation of the aquifer response, including hydraulic monitoring, numerical modeling, and contaminant monitoring in the 100-D Area, is discussed in Section 2.3. An evaluation of the aquifer response in the 100-H Area is presented in Section 2.4. Section 2.5 summarizes quality assurance(QA)/quality control (QC) for groundwater samples. Section 2.6 presents conclusions on progress toward achieving each RAO and the performance criteria. Section 2.7 summarizes issues that need further evaluation and Section 2.8 provides recommendations to change/enhance the 100-HR-3 OU pump-and-treat system. Cost information is presented separately in Section 5.0.

\section{$2.1 \quad$ HISTORY OF OPERATIONS}

In September 1994, the Limited Field Investigation Report for the 100-HR-3 Operable Unit (DOE-RL 1993), including the qualitative risk assessment, was completed. Hexavalent chromium was identified as a COC for ecological receptors in the river. In August 1995, the focused feasibility study (DOE-RL 1995a) and the proposed plan (DOE-RL 1995d) were finalized. The proposed plan recommended a pump-and-treat system to mitigate chromium migration into the river. In 1994, a pilot-scale pump-and-treat system was deployed, and in December 1995 the pilot-scale treatability test summary report (DOE-RL 1995c) for the 100-HR-3 OU was issued. The report indicated that removing hexavalent chromium from extracted groundwater in the 100-HR-3 OU using a resin treatment (IX) system was viable.

In April 1996, an interim remedial action ROD (EPA 1996) was issued for the pump-and-treat system for the 100-HR-3 OU. The ROD specified installation of a pump-and-treat system in the 100-HR-3 and 100-KR-4 OUs to intercept portions of the hexavalent chromium plumes that impact the Columbia River. Full-time operation of the 100-HR-3 treatment system was initiated July 1, 1997. On August 5, 1998, the pump-and-treat system was modified to permit groundwater from the 100-D Area to be treated separately from the 100-H Area groundwater. 
In October 1999, an amendment to the interim remedial action ROD (EPA 1999a) was approved that modified the selected remedial action by deploying a new innovative treatment technology, In Situ Redox Manipulation (ISRM), to address the groundwater chromium plume located southwest of the 100-D/DR Reactor.

Additional detailed site characterization and background information on the OU and the pumpand-treat activity are provided in the Limited Field Investigation Report for the 100-HR-3 Operable Unit (DOE-RL 1993) and in the 100-HR-3 Operable Unit Focused Feasibility Study (DOE-RL 1995a). Further information on the pump-and-treat system design and operation can be found in the remedial design report/remedial action work plan (DOE-RL 1996b) and the 100-HR-3 and 100-KR-4 Operable Units Interim Action Performance Evaluation Report (DOE-RL 1998). Groundwater monitoring requirements are described in the Interim Action Monitoring Plan for the 100-HR-3 and 100-KR-4 Operable Units (DOE-RL 1997a). Other background/current information is available in the Hanford Site Groundwater Monitoring for Fiscal Year 2000 (PNNL 2000a).

Other relevant activities that were completed in CY 2000 for the 100-HR-3 OU include the following:

- Significant vadose remediation occurred during CY 2000. Soil from waste sites, cribs, pipelines, and trenches around the 100-D and 100-H Areas was excavated to a depth of $4.6 \mathrm{~m}$ $(15 \mathrm{ft})$. Remediation activities consisted of excavating contaminated soil and debris, disposing of the contaminated materials in the Environmental Restoration Disposal Facility, and backfilling the excavation with clean overburden. Removal of contaminated soils should have some impact to improve the water quality of groundwater in the 100-HR-3 OU by removing contributing vadose sources of contamination. Fifteen 100-D Area waste sites and six 100-H Area waste sites have been remediated that could have impacted groundwater quality.

- Aquifer tube sampling was conducted in the fall of 2000 along the Columbia River low-water shoreline of the 100-D and 100-H Areas. A report detailing the sampling results will be issued in CY 2001. (Note that aquifer tube sampling was broader in overall scope than the $100-\mathrm{D}$ and $100-\mathrm{H}$ Areas. The area of shoreline coverage extended from up river of the B Reactor in the 100 Areas to the F Reactor area.)

- The new extraction well (199-H4-65) that was installed in CY 1999 has been operational during CY 2000.

- Phase I of the In Situ Redox Manipulation (ISRM) technology was implemented to remediate the western hexavalent chromium plume at the 100-D Area. A detailed description of the progress and performance of the ISRM technology will not be covered in this report, but can be found in the Fiscal Year 2000 Annual Summary Report for In Situ Redox Manipulation Operations (DOE-RL 2001). 
- The U.S. Environmental Protection Agency (EPA) initiated a review of remedial actions at the Hanford Site, including the 100-HR-3 pump-and-treat system, in accordance with CERCLA requirements.

\subsection{TREATMENT SYSTEM PERFORMANCE}

This section describes the 100-HR-3 pump-and treat system operation and sampling that occurred from January 1, 2000, through December 31, 2000. Specific details include system availability, changes to the system configuration, mass of contaminants removed during operations, contaminant removal efficiencies, quantity and quality of extracted and disposed groundwater, waste generation, and contaminant trends.

\subsubsection{System Operation}

Groundwater is withdrawn from the aquifer by two extraction wells in the 100-D Area (199-D8-53 and 199-D8-54A) and six extraction wells in the 100-H Area (199-H3-2A, 199-H4-7, 199-H4-11, 199-H4-12A, 199-H4-15A, and 199-H4-65). The extracted groundwater is pumped into an influent storage tank, through the IX treatment system, and into the effluent storage tank. Treated water is pumped from the effluent storage tank into three injection wells (199-H3-3, 199-H3-4, and 199-H3-5) that are located upgradient of the contaminant plume in the 100-H Area. A schematic of the treatment system is included in Figure 2-4.

The following is a summary of treatment of $100-H R-3$ groundwater:

100-HR-3 groundwater treated since July 1997 startup:

100-H groundwater treated since July 1997 startup:

100-D groundwater treated since July 1997 startup:

100-HR-3 groundwater treated during CY 2000:

Groundwater treated from 100-H during CY 2000:

Groundwater treated from 100-D during CY 2000:

100-HR-3 hexavalent chromium removed (since July 1997 startup):

100-H hexavalent chromium removed since July 1997 startup:

100-D hexavalent chromium removed since July 1997 startup:

Total amount of hexavalent chromium removed during CY 2000:

100-H hexavalent chromium removed during CY 2000:

100-D hexavalent chromium removed during CY 2000:
958.7 million $\mathrm{L}$ 505.4 million $\mathrm{L}$ 453.3 million $\mathrm{L}$ 305.1 million $\mathrm{L}$ 169.4 million $\mathrm{L}$ 135.7 million $\mathrm{L}$

$104.3 \mathrm{~kg}$

$25.1 \mathrm{~kg}$

$79.2 \mathrm{~kg}$

$30 \mathrm{~kg}$

$4.7 \mathrm{~kg}$

$25.3 \mathrm{~kg}$

Table 2-1 provides a detailed comparison of CY 2000 operational statistics to CY 1999. The average CY 2000 hexavalent chromium concentration in the $100-\mathrm{H}$ Area influent was $34 \mu \mathrm{g} / \mathrm{L}$, ranging from as high as $49 \mu \mathrm{g} / \mathrm{L}$ to as low as undetected with a detection limit of $5 \mu \mathrm{g} / \mathrm{L}$ (Table 2-2). The average hexavalent chromium concentration in the 100-D Area influent was $192 \mu \mathrm{g} / \mathrm{L}$, ranging from as high as $313 \mu \mathrm{g} / \mathrm{L}$ to as low as $49 \mu \mathrm{g} / \mathrm{L}$. Hexavalent chromium concentrations in the effluent averaged $7 \mu \mathrm{g} / \mathrm{L}$. Trend plots of the influent and effluent concentrations can be found in Figure 2-5. 
CY 2000 removal efficiency exceeded $93 \%$ (Table 2-1), which is down from previous years (Figure 2-6). The lower removal efficiencies can be attributed to problems encountered with improper vessel realignments after vessel changeouts in May and August. The highest chromium concentration in the treatment effluent was $46 \mu \mathrm{g} / \mathrm{L}$ and the average effluent concentration was $7 \mu \mathrm{g} / \mathrm{L}$.

An IX process is used to remove hexavalent chromium from extracted groundwater. Four separate IX treatment skids, each with 379-L/min capacity, are housed in the 1713-H Treatment Building. Only two of the skids are used at any one time, while the other two serve as backup. Therefore, the maximum processing rate for the treatment system is $758 \mathrm{~L} / \mathrm{min}$. During CY 2000 , the average process flow rate was $663.7 \mathrm{~L} / \mathrm{min}$, which is $87.6 \%$ of the maximum processing flowrate capacity.

During 2000 , a total of 26 spent IX vessels were changed out. Typically, the lead vessel of a treatment train is changed out when the effluent from the vessel reaches $80 \%$ of the influent value. Fifteen resin vessels were changed out for the 100-D Area groundwater treatment train, averaging 98 days of use per vessel. Twelve vessels were changed out for the 100-H Area groundwater treatment train (each vessel has an average longevity of 133 days).

From the initiation of system operations through August 4, 1998, groundwater from both the 100-D and 100-H Areas was treated as a combined influent. On August 5, 1998, the influent for the 100-D and 100-H Areas was separated and treated with separate IX treatment units to minimize generation of low-level radioactive waste that had resulted from the gradual increase of technetium-99 in 100-H Area groundwater. Spent IX resin containing sorbed technetium-99 was designated as a low-level radioactive waste and could not be shipped from the Hanford Site. The regeneration remaining spent resin is sent offsite for regulation. The vessels that were changed out equate to $62.7 \mathrm{~m}^{3}$ of spent resin, of which $13.8 \mathrm{~m}^{3}$ came from regenerated resin (Table 2-1).

Total system availability for CY 2000 exceeded $97 \%$ (time on-line/(total hours during the year minus scheduled outages). Significant outages for CY 2000 are listed in detail in Figure 2-7. The on-line availability was slightly less at $95.6 \%$ (time on-line/total hours during the year). This is an increase from the on-line availability of $91.9 \%$ reported for the previous performance evaluation period, CY 1999.

System operators monitor the levels of hexavalent chromium by weekly sampling of extraction wells and influent and effluent ports and then analyze these samples. Field technicians collect quarterly samples from the extraction wells and influent and effluent ports, analyze for hexavalent chromium, and compare the results to the operator's results to provide quality control. The technicians additionally collect and analyze duplicates to provide precision to their results. The duplicate results are displayed in Table 2-3. The relative percent difference (RPD) for the duplicates ranged from $-7 \%$ to $8 \%$.

The results obtained by the operators were compared to those obtained by the technicians by calculating the RPD for a sample pair. However, the sample pairs were not collected on the same day, so the technician's quarterly sample from a well or sample port was paired with the 
closest weekly operator's sample from the same location. The RPD was calculated by subtracting the operator's result from the technician's result and dividing by the average of the two sample results. The RPDs for the sample pairs described above are included in Table 2-4. The RPDs range from $5 \%$ to $73 \%$. The average RPD value for the data was $22.3 \%$. All of the RPDs were positive, indicating that the technician's results were higher than the operator's results. The average of the measurements and the RPDs for the measurements are shown graphically in Figure 2-8.

Additionally, some quarterly technician's samples were split and analyzed by an offsite laboratory to assess the analytical precision of chromium analysis using the field Hach hexavalent chromium method compared to EPA Method 7196 (EPA 1986). The field analysis was compared to the laboratory split by calculating the RPD for the sample pair. The RPD was calculated by subtracting the field result from the laboratory result and dividing by the average of the two sample results. As shown in Table 2-5, the 100-HR-3 split RPDs ranged from $-59 \%$ to $7 \%$, and the average RPD of the splits was $-13.3 \%$, indicating the field results were higher than the laboratory results.

\subsubsection{Operations Wells}

Seven extraction wells have been operating since the initiation of operations in July 1997. An eighth well, 199-H4-65, was installed in CY 1999 and was put in operation in CY 2000. Well 199-H4-65, however, pumped dry on August 26, 2000, and continued dry through the end of the year. This can be attributed to dropping river stages. Sample data collected from these wells were used for monitoring process operations and evaluating the aquifer's response to remediation activities. The eight extraction wells are as follows:

- 199-D8-53

- 199-D8-54A

- 199-H3-2A

- $199-\mathrm{H} 4-7$

- 199-H4-11

- 199-H4-12A

- 199-H4-15A

- 199-H4-65.

The average groundwater extraction rate for the eight-well extraction system was $663.7 \mathrm{~L} / \mathrm{min}$. Of this total, approximately $286 \mathrm{~L} / \mathrm{min}$ is attributed to wells in the $100-\mathrm{D}$ Area and $378 \mathrm{~L} / \mathrm{min}$ is attributed to wells in the 100-H Area. Production rates for the wells within the extraction system ranged from 45 to $147 \mathrm{~L} / \mathrm{min}$. The system continues to use three injection wells (199-H3-3, 199$\mathrm{H} 3-4$, and 199-H3-5), all located upgradient of the contaminant plume in the 100-H Area.

\subsubsection{Operational Monitoring and Sampling}

In addition to system parameters, operators sample the process water to monitor the performance of the pump-and-treat system and to ensure that the system is effectively meeting the requirements of the interim remedial action ROD (EPA 1996). Operational samples are taken 
from five categories of sources for the pump-and-treat system: extraction wells, 100-H Area influent to the treatment system, 100-D Area influent to the treatment system, effluent from the treatment system, and each of the IX vessels in use. The specific sample points are identified in Figure 2-4 as sample collection points (SC) or alternative sample collection points (HP).

Water from each sample point is sampled and field analyzed during manned operations to monitor chromium levels. Field screening has been used to reduce operational costs and to provide process data to operators in real-time. As previously mentioned, influent and effluent are sampled and analyzed offsite quarterly for hexavalent chromium. For semi-annual samples, conductivity and co-contaminants are analyzed in addition to hexavalent chromium. Cocontaminants for the 100-D Area are strontium-90 (measured as total beta radiostrontium) and tritium; co-contaminants for the 100-H Area are nitrate, strontium- 90 (measured as total beta radiostrontium), technetium- 99 , tritium, and uranium. This satisfies the performance criteria analytical requirements for sampling of the treatment system.

2.2.3.1 Hexavalent Chromium in Extraction Wells. The average hexavalent chromium results for CY 1997 through CY 2000 are summarized in Table 2-2. The CY 2000 results are summarized as follows:

- Concentrations in the 100-D Area extraction wells during CY 2000 increased compared to CY 1999 values. CY 2000 concentrations in wells 199-D8-53 and 199-D8-54A averaged $136 \mu \mathrm{g} / \mathrm{L}$ and $240 \mu \mathrm{g} / \mathrm{L}$, respectively, compared to $107 \mu \mathrm{g} / \mathrm{L}$ and $135 \mu \mathrm{g} / \mathrm{L}$, averaged for the same wells in CY 1999.

- Average concentrations decreased from CY 1999 to CY 2000 in 100-H Area extraction wells 199-H4-7 and 199-H4-11. CY 2000 average concentrations were $45 \mu \mathrm{g} / \mathrm{L}$ and $38 \mu \mathrm{g} / \mathrm{L}$, respectively. Well 199-H3-2A had hexavalent chromium concentrations below the RAO during all of CY 2000, with a maximum concentration of $21 \mu \mathrm{g} / \mathrm{L}$ and a minimum concentration that was undetected with a detection limit of $5 \mu \mathrm{g} / \mathrm{L}$.

- Wells 199-H4-12A and 199-H4-15A had stable hexavalent chromium concentration comparing CY 1999 with CY 2000 averages of $51 \mu \mathrm{g} / \mathrm{L}$ and $47 \mu \mathrm{g} / \mathrm{L}$, respectively. "Stable" for this comparison has been defined as a change of less than $20 \%$. The new extraction well, 199-H4-65, had the highest FY 2000 average hexavalent chromium concentration in the $100-\mathrm{H}$ Area with a value of $60 \mu \mathrm{g} / \mathrm{L}$.

2.2.3.2 Co-Contaminants in Extraction Wells. Average co-contaminant data for the extraction wells can be found in Table 2-6. The CY 2000 results are summarized below.

- Nitrate: 100-D Area extraction well samples are not analyzed for nitrate, because it is not a contaminant of potential concern in the 100-D Area. Samples from all six 100-H Area extraction wells were analyzed for nitrate during CY 2000. Two wells, 199-H4-7 and 199-H4-65, were above the $45 \mathrm{mg} / \mathrm{L}$ maximum contaminant level (MCL) for nitrate with concentrations of $53 \mathrm{mg} / \mathrm{L}$ and $82 \mathrm{mg} / \mathrm{L}$, respectively. All other wells had stable or decreasing nitrate trends. 
- Total beta radiostrontium: Both 100-H and 100-D Area extraction wells with detectable activity had stable or decreasing trends in total beta radiostrontium in CY 2000.

Well 199-H4-11 had an average activity of $19 \mathrm{pCi} / \mathrm{L}(+/-2.1)$, which is above the drinking water standard for strontium- 90 of $8 \mathrm{pCi} / \mathrm{L}$. However, average activity in this well has been decreasing since CY 1998. All of the other extraction wells had CY 2000 average activities below $8 \mathrm{pCi} / \mathrm{L}$.

- Technetium-99: The 100-H Area wells were below the MCL for technetium-99 of $900 \mathrm{pCi} / \mathrm{L}$. The highest CY 2000 average activity of technetium-99 was $166 \mathrm{pCi} / \mathrm{L}(+/-22)$ in the new extraction well, 199-H4-65. Technetium-99 is not a contaminant of potential concern for wells in the 100-D Area; therefore, samples from wells 199-D8-53 and 199-D8$54 \mathrm{~A}$ are not tested for technetium-99 contamination.

- Tritium: Samples from both 100-H and 100-D Area extraction wells were far below the MCL for tritium of $20,000 \mathrm{pCi} / \mathrm{L}$. The highest average activity of tritium was $3,780 \mathrm{pCi} / \mathrm{L}$ $(+/-440)$, which was found in the new extraction well, 199-H4-65.

- Uranium: The 100-H Area well samples that were collected during CY 2000 were below the MCL of $20 \mu \mathrm{g} / \mathrm{L}$ for total uranium. The highest average concentration of uranium was $15.8 \mu \mathrm{g} / \mathrm{L}(+/-3.8)$, which was found in well 199-H4-12A. Samples from wells 199-H4-65 and 199-H3-2A were not analyzed for total uranium during CY 2000. The 100-D Area extraction well samples are not analyzed for uranium, because it is not a contaminant of potential concern in the 100-D Area.

Contaminant trend plots for the 100-HR-3 extraction wells can be found in Appendix A. In summary, operational sampling in the 100-HR-3 wells in CY 2000 showed no dramatic changes in contaminant concentrations; however, there appears to be an overall decrease in contaminant concentrations at both sites.

\subsection{AQUIFER RESPONSE IN THE 100-D AREA}

Water level, hexavalent and total chromium concentrations, and groundwater chemistry measurements were collected at wells located in the 100-D Area as part of Resource Conservation and Recovery Act of 1976 (RCRA), CERCLA, and interim remedial action performance monitoring. Monitoring requirements specific to the interim remedial action are listed in DOE-RL (1996b) and DOE-RL (1997a). The monitoring program collects data to determine the aquifer hydraulic and hydrochemical response to pump-and-treat operations.

Section 2.3.1 provides details of the measured hydraulic responses, Section 2.3.2 provides a discussion of the hydraulic capture exerted by the pump-and-treat system, and Section 2.3 .3 discusses the measured chemical responses to the pump-and-treat system.

The 1996 ROD for the 100-HR-3 OU was modified in 1999 (EPA 1999a) to authorize deployment of the ISRM technology to remediate the chromium plume west of the D/DR Reactors. This plume is not within the established treatment zone for the pump-and-treat system 
for the interim action. The initial phase of the ISRM remedial action was implemented in 2000. The monitoring results of the ISRM are reported in the 100-D/DR Area ISRM Fourth-Quarter FY 2000 Technical Memorandum (Miller et al. 2001) and the ISRM FY 2000 Annual Report (DOE-RL 2001).

\subsubsection{Hydraulic Monitoring}

Evaluating the impact of the pump-and-treat system on the aquifer requires distinguishing between water-level changes caused by the extraction wells from those caused by changes in river stage. Drawdown in the extraction and monitoring wells provides measurable and quantifiable evidence of the hydraulic impact on the aquifer by the pump-and-treat system.

To determine the hydraulic impacts of the pump-and-treat system, hourly water-level data were collected from the operations and monitoring wells and correlated to hourly river-stage data. Regression lines were fit to the water-level data collected while the extraction wells were operating and to the data collected while the extraction wells were shut down. Offsets in the regression lines corresponding to pumping startup or shutdown were used to determine the drawdown in the wells within the immediate influence of the river. To minimize the amount of skew in the aquifer water-level data resulting from trends in the river stage, the analysis was limited to pcriods when the river stage remained relatively constant, with no sudden or large changes relative to the daily cycles.

2.3.1.1 Extraction Wells. Extraction wells 199-D8-53 and 199-D8-54A operate in the 100-D Area (Figure 2-2). The water-level data and correlation lines used to calculate the drawdown in the extraction wells are included in Appendix B and the results are summarized in Table 2-7.

2.3.1.2 Monitoring Wells. Five monitoring wells are currently equipped with pressure transducers and data loggers that record hourly water-level measurements. The maximum drawdown was $0.04 \mathrm{~m}$ in well 199-D8-71, which is located between the two extraction wells. Approximately the same magnitude of drawdown $(0.02 \mathrm{~m}+/-0.01 \mathrm{~m})$ was measured in the three compliance wells: 199-D8-68 (located between well 199-D8-54A and the river), well 199-D8-69 (located northwest of well 199-D8-53), and well 199-D8-70 (located northeast of well 199-D8-53) (Figure 2-2). The effects of the pump-and-treat operation have not been detected in well 199-D8-54B, which is screened below the Ringold Upper Mud Unit (RUM). The well is located adjacent to extraction well 199-D8-54A, which is screencd in the unconfined aquifer above the RUM. The water-level data and correlation lines used to calculate the drawdown in the monitoring wells are contained in Appendix B and the results are summarized in Table 2-7.

\subsubsection{Numerical Modeling}

Steady-state numcrical groundwater models (e.g., Micro-Fem ${ }^{\mathrm{rM}}$ ) were used to estimate and evaluate the hydraulic capture of the pump-and-treat system in the 100-D Area. The objectives

\footnotetext{
${ }^{\mathrm{r}}$ Micro-Fem is a trademark of C. J. Hemker, The Netherlands.
} 
of the modeling are to show the extent of the impact on the aquifer by the extraction wells and to quantify the effectiveness of the pump-and-treat system in reducing the flux of contaminants into the river. The modeling results also provide input to operations in an effort to optimize the pumping rates on the basis of hydraulic capture. The development, assumptions, and limitations of the models for all four areas are similar and presented Appendix K.

Flow lines terminating at the extraction wells in Figures 2-9 and 2-10 show the area of the aquifer through which each extraction well removes groundwater and the chromium carried in the water. Wells 199-D8-53 and 199-D8-54A fully penetrate the unconfined aquifer, so the flow lines represent the groundwater travel occurring throughout the depth of the aquifer. The total area encompassed by the flow lines terminating at each extraction well represents the capture zone of that extraction well. Flow lines terminating at the river in Figure 2-10 indicate areas where the groundwater passes uncaptured by the extraction wells and discharges into the river. Figures 2-9 and 2-10 also show the chromium plume distribution. A comparison of the modeled water levels to the actual water levels measured in November is presented in Table 2-7.

The flow lines forming the capture zones of the two extraction wells meet, indicating that the extraction wells capture essentially all of the groundwater passing between them (Figure 2-9). The composite capture zone of the two extraction wells extends laterally from well 199-D8-70 to well 199-D8-68 and southward toward wells 199-D5-14, 199-D5-15, and 199-D5-16. Pumping has reduced the hydraulic gradient between the aquifer and the river, thus reducing the discharge of contaminated groundwater into the river. Under these conditions, pumping in the extraction wells hydraulically contains the aquifer along the shoreline of the river between compliance wells 199-D8-68 and 199-D8-69.

To assess quantitatively the relative effectiveness of the hydraulic barrier caused by the extraction wells and to identify areas where groundwater from the target area may flow uncaptured to the river, a series of 50 flow lines was added to the capture analysis (Figure 2-10). The flow lines indicate where a particle of water travels in the aquifer and whether the groundwater is captured by the extraction wells or discharges into the river. The series was placed upgradient of the extraction wells within the area originally defined as the target area of the pump-and-treat system (Figure 3-3 in DOE-RL [1996b]). The extraction wells capture 42 of the 50 flow lines, suggesting that the pump-and-treat system captures a similar proportion of the groundwater flowing through approximately $84 \%$ of the target (remediation) area.

\subsubsection{Contaminant Monitoring}

This section summarizes and interprets 100-D Area analytical results obtained from groundwater wells included in the interim remedial action and OU monitoring programs supporting the 100-HR-3 pump-and-treat system.

The principal COC in the 100-D Area is chromium. Co-contaminants are strontium-90, tritium, and sulfate. Section 2.3.3.1 discusses the results of chromium monitoring, and Section 2.3.3.2 discusses the results of co-contaminant monitoring. The locations of the monitoring wells and aquifer sampling tubes are shown in Figure 2-2. Chromium trend plots and conductivity plots are included in Appendix D. 
2.3.3.1 Chromium Monitoring Results. Chromium is monitored throughout the 100-D Area in compliance, extraction, and monitoring wells, and at sample tube locations along the Columbia River. Monitoring is also performed at four riverbank seeps located along the steep slopes adjacent to the river. The number of groundwater monitoring locations and sampling frequencies in the 100-D Area are identified in Table 2-8. Appendix E contains a sampling schedule with specific wells and requested analyses. Specific requirements for the groundwater monitoring for CY 2000 is provided in the Interim Action Monitoring Plan for the 100-HR-3 and 100-KR-4 Operable Units (DOE-RL 1997a). Construction details and the use of each well in the 100-D Area network are presented in Table 2-9.

Control of sampling waste became an issue during CY 2000 and resulted in adjustments to the quarterly and monthly sampling events. The March and April monthly compliance monitoring events were canceled. Consequently, eight OU monitoring wells scheduled for sampling in February 2000 (wells 199-D3-2, 199-D4-14, 199-D4-20, 199-D4-22, 199-D4-23, 199-D5-14, 199-D5-15, and 199-D8-55) were not sampled.

Changes in the chromium distribution in groundwater have occurred in the 100-D Area since the baseline chromium plume map was developed in 1995. Figure 2-11 presents the baseline chromium distribution map and successive maps developed for fall 1998, fall 1999, and fall 2000 chromium concentrations. Previous monitoring results indicate that chromium concentrations are strongly influenced by river stage in the 100-D Area. Therefore, chromium distribution maps are based on fall monitoring results because river levels are generally at a seasonal low and have minimum influence on groundwater conditions during this time period. The water quality data used to develop the fall 2000 chromium distribution include the following:

- September 2000 compliance well and OU monitoring well results

- The average of early September, mid-September, and late September 2000 weekly extraction well monitoring results (collected by the process operator)

- November 2000 sample tube data

- October 2000 groundwater seep data.

Because of the proximity of the sample tubes and riverbank seepage to the river, the groundwater quality at these sampling locations generally experiences a greater degree of river influence. Therefore, the sample tube and seep data are considered only qualitatively in developing the fall 2000 chromium distribution map.

The changes in chromium distribution depicted in Figure 2-11 can be attributed to actual in situ chromium concentration changes as well as apparent changes in chromium distribution due to additions to the monitoring well network. A significant change in chromium distribution is evident in the differences between the 1996 baseline map and the fall 1998 map. These differences stem primarily from the addition of new monitoring wells installed in 1997 in the ISRM area. The new wells revealed the presence of a separate southwestern chromium plume in the ISRM area as shown in the fall 1998 map. The installation of additional monitoring wells 
across the 100-D Area further refined the chromium distribution as illustrated by comparing fall 1998 and fall 1999 maps.

Fall 1999 and fall 2000 chromium distributions in groundwater are shown separately in Figure 2-11 and in an overlay format in Figure 2-12. The 2000 chromium distribution pattern is similar to the distribution observed in 1999; two separate chromium plumes are present in the 100-D Area. The center of the northeastern plume is located beneath, and downgradient of, the $\mathrm{D}$ Reactor and retention basins. The southwestern plume appears to be centered downgradient of the historic 190-DR Clearwells location and south of the 182-D Reservoir. As previously noted, the southwestern plume is discussed in Fiscal Year 2000 Annual Summary Report for the In Situ Redox Manipulation Operation (DOE-RL 2001) along with the associated remediation activities; therefore, the chromium contamination in this area is not addressed in this report.

Average annual chromium concentrations for the years 1997 through 2000 are presented in Table 2-10. The annual averages were developed using the following guidelines: only filtered results were used; duplicate sample results were averaged; laboratory splits were not included; and the detection limit value was used for nondetection results. The short-term trend results are also presented in Table 2-10. Short-term chromium concentration trends at individual wells were evaluated by comparing the 1999 and 2000 annual averages. The short-term concentration trend was considered stable if the RPD between 1999 and 2000 averages was less than $20 \%$. The CY 2000 averages for monitoring wells included two or three quarterly sampling events. The November 2000 sample analyses were not available for the preparation of this report.

Longer-term trends in chromium concentration at specific wells were assessed by visual inspection of the chromium concentration versus time plots presented in Figure 2-12 and contained in Appendix D.

The following key items or highlights should be noted regarding chromium in the 100-D Area for CY 2000.

- Compliance wells (199-D8-68, 199-D8-69, and 199-D8-70). Average annual chromium concentrations in the compliance wells were higher than average concentrations in CY 1999 , indicating a short-term increasing trend (Table 2-10). The CY 2000 average annual chromium concentrations in these wells were $196 \mu \mathrm{g} / \mathrm{L}, 85 \mu \mathrm{g} / \mathrm{L}$, and $191 \mu \mathrm{g} / \mathrm{L}$, respectively. These values exceed the remediation goal of $22 \mu \mathrm{g} / \mathrm{L}$. The short-term increase in concentrations may be attributed to lower river levels in the summer and fall of 2000 . Also, the cancellation of the March and April monthly sampling, typically when chromium concentrations are lower, probably raised the annual average for these wells.

Long-term chromium concentrations appear to vary seasonally with a slight increasing trend between 1997 and 2000 (Appendix D). Seasonal variations are most pronounced in wells 199-D8-68 and 199-D8-69, and are present to a lesser degree in well 199-D8-70. The highest chromium concentrations are observed in the late fall (November and December) during the period of lowest river stage (i.c., the period of minimal river influence on groundwater quality). 
- Extraction wells (199-D8-53 and 199-D8-54A). Average annual chromium concentrations in the extraction wells were also higher in 2000 than in 1999 , indicating a short-term increasing trend (Table 2-10). As with the compliance wells, the increase may be attributed to the effect of the lower river stage in 2000. Average 2000 chromium concentrations were $129 \mu \mathrm{g} / \mathrm{L}$ and $231 \mu \mathrm{g} / \mathrm{L}$, respectively. The long-term chromium trend appears stable (i.e., concentrations vary within a consistent range) between 1997 and 2000, with distinct seasonal variations in well 199-D8-54A and to a lesser degree in 199-D8-53 (Figure 2-12). The stable long-term trends in chromium concentrations in the extraction wells and the similar chromium distribution patterns from year to year suggest that the pump-and-treat system is still drawing water from the high-concentration portion of the plume after 3.5 years of operation.

- Monitoring wells. Increasing concentrations in a number of the northeastern plume perimeter wells in 2000 suggest that the chromium plume has expanded slightly. Chromium concentrations remain below detection at monitoring wells 199-D5-42 and 199-D5-44, establishing the southwestern limits of the chromium plume. Of the monitoring wells listed in Table 2-10, two wells displayed short-term decreasing trends between 1999 and 2000, and eight wells were stable or could not be trended because of insufficient data. Six monitoring wells displayed short-term increasing trends; large increases in average annual chromium occurred at three wells, 199-D5-13, 199-D5-20, and 199-D5-41. These increasing average annual concentration trends are consistent with the changes in chromium distribution shown in Figures 2-11 and 2-12.

Long-term chromium trends in monitoring wells are presented in Figure 2-11 and Appendix D. Monitoring wells 199-D8-4, 199-D8-5, 199-D8-55, 199-D5-14, 199-D5-17, and 199-D5-20 exhibit an increasing chromium trend between 1997 and 2000. A decreasing chromium trend was observed in wells 199-D5-15 and 199-D5-16.

Concentration trend plots in Figure 2-12 show that chromium concentrations in monitoring wells 199-D5-13, 199-D5-20, 199-D5-41, 199-D8-4, 199-D8-5, and 199-D8-6 have increased since 1997. The increasing concentration trend in these wells suggests that a chromium plume is migrating towards the river, probably because the groundwater mound from the D Pond area has been eliminated.

Average annual chromium concentrations in monitoring wells 199-D5-15 and 199-D5-16, located on the upgradient side of the 108-D Building, have decreased over the same period (Table 2-10). This decline in chromium concentration might indicate that wells 199-D5-15 and 199-D5-16 are located near the upgradient edge of the chromium plume (i.e., chromium is decreasing due to natural groundwater transport processes in the vicinity of these wells). The decrease in chromium concentrations observed in wells 199-D5-18 and 199-D5-19 between the baseline and 1999 provides additional support that the chromium plume is moving toward the river (Figure 2-11).

The current interim groundwater extraction system was originally designed and installed as a hydraulic barrier to prevent groundwater with high chromium concentrations shown in the baseline distribution map (Figure 2-11) from reaching the Columbia River. The monitoring wells with increasing chromium concentrations, particularly those downgradient of the D 
Pond area, are located outside the influence of the existing groundwater extraction system (Figures 2-9 and 2-10).

- Aquifer sampling tubes. Aquifer sampling tube data from the fall of 2000 sampling event are generally consistent with groundwater monitoring well data (Figure 2-12). The value of the aquifer sample tube data is in providing chromium concentrations close to the river in areas where there is no well control. Chromium concentrations were obtained from 11 sample tubes in the 100-D Area, all of which exceeded the goal of $22 \mu \mathrm{g} / \mathrm{L}$. Specific conductance of samples from these tubes ranged from 254 to $598 \mu \mathrm{S} / \mathrm{cm}$.

- Depth-discrete sampling in 199-D8-70. Discrete groundwater samples were collected at different depth intervals in the unconfined aquifer at well 199-D8-70. Similar to the 1999 results, no stratification or layering of chromium contamination was observed in CY 2000 , even during different river stages. It is concluded that chromium concentrations are relatively constant throughout the entire saturated thickness of the unconfined aquifer. Samples were collected from the following depth intervals: 15.2 to $15.8 \mathrm{~m}, 16.5$ to $17 \mathrm{~m}$, and 19 to $19.5 \mathrm{~m}$. The early November results were $228 \mu \mathrm{g} / \mathrm{L}, 232 \mu \mathrm{g} / \mathrm{L}$, and $231 \mu \mathrm{g} / \mathrm{L}$, respectively.

- Groundwater Seeps (110-1 and 110-2). Samples were collected from riverbank seeps 110-1 and 110-2 on October 17, 2000. As shown in Figure 2-11, chromium concentrations were $89 \mu \mathrm{g} / \mathrm{L}$ and $35 \mu \mathrm{g} / \mathrm{L}$, respectively. These results are lower than concentrations observed in nearby compliance wells, but exceed the remediation goal of $22 \mu \mathrm{g} / \mathrm{L}$.

2.3.3.2 Co-Contaminant Monitoring Results. Co-contaminants in the 100-D Area include strontium-90, tritium, nitrate, and sulfate (DOE-RL 1996b). Table 2-11 presents the average annual co-contaminant concentrations and short-term concentration trends where they could be developed. The results of the co-contaminant monitoring for $2000 \mathrm{in}$ monitoring wells are summarized as follows:

- Strontium-90. The 2000 average annual strontium-90 activity in well 199-D8-68 was higher than the average activity in 1999 indicating a short-term increasing trend. A short-term decreasing trend was observed in well 199-D8-70, and the average annual activity remained stable in well 199-D8-69 between 1999 and 2000.

- Tritium. Average annual tritium activities in three wells (199-D8-68, 199-D8-69, and 199-D8-70) were higher than average activities in CY 1999 indicating a short-term increasing trend. One well (199-D8-4) displayed a short-term decreasing trend, and four wells (199-D5-37, 199-D5-42, 199-D5-44, and 199-D8-54B) had stable tritium activity between 1999 and 2000 .

- Nitrate. Nitrate concentrations were obtained from four wells in 2000 . The average annual nitrate concentration in wells 199-D8-6 and 199-D5-42 were higher than the average concentration in 1999 , indicating a short-term increasing trend.

- Sulfate. Average annual sulfate concentrations in five wells (199-D5-37, 199-D5-42, 199-D5-44, 199-D8-4, and 199-D8-54B) exhibited stable short-term trends. Only one well 
(199-D8-6) displayed a short-term increasing trend. However, the sulfate trend plots in Appendix D indicate that many of the 100-D monitoring wells are experiencing long-term upward trends in sulfate concentration.

\subsection{AQUIFER RESPONSE IN THE 100-H AREA}

Water level, chromium concentrations, and other groundwater chemistry measurements were collected at wells located in the 100-H Area as part of RCRA, CERCLA, and interim remedial action performance monitoring. Monitoring requirements specific to the interim remedial action are listed in DOE-RL (1996b) and DOE-RL (1997a). The monitoring program collects data to determine the aquifer hydraulic and hydrochemical response to pump-and-treat operations.

Section 2.4.1 provides details of the measured hydraulic responses, Section 2.4 .2 provides a discussion of the numerical modeling, and Section 2.4.3 discusses the analytical results obtained from groundwater wells in the 100-HR-3 OU.

\subsubsection{Hydraulic Monitoring}

Five extraction wells and three injection wells currently operate in the 100-H Area. Three of the extraction wells are located within $75 \mathrm{~m}$ of the Columbia River shoreline (Figure 2-3).

To determine the hydraulic impacts of the pump-and-treat system near the river, the same method of analyzing the 100-D Area hourly water-level data was used.

2.4.1.1 Extraction and Injection Wells. Production data for the 100-H Area extraction wells show that well 199-H4-11 consistently sustained the highest flow rate for all extraction wells during the year. Well 199-H4-11 showed a drawdown of $0.33 \mathrm{~m}$, while wells 199-H4-12A and 199-H4-15A showed a drawdown of $0.61 \mathrm{~m}$ and $0.33 \mathrm{~m}$, respectively. Well 199-H4-7 consistently sustains the lowest flow rate of the extraction wells, with the flow rate averaging $46 \mathrm{~L} / \mathrm{min}$ during the period analyzed and the drawdown measuring $0.43 \mathrm{~m}$. Extraction well $199-\mathrm{H} 3-2 \mathrm{~A}$ is the most productive of the extraction wells, yielding a flow rate of $74 \mathrm{~L} / \mathrm{min}$, with $0.10 \mathrm{~m}$ of drawdown. This well is located the farthest inland of the extraction wells, about $500 \mathrm{~m}$ from the Columbia River shoreline.

Very little buildup continues to occur in the $100-\mathrm{H}$ Area injection wells, which indicates that the injection wells are highly efficient and suggests that no decrease in injection efficiency from clogging has occurred. Water turbulence and unsteady injection rates result in scattered water-level data, making it difficult to determine the actual buildup With injection rates averaging $162 \mathrm{~L} / \mathrm{min}$ in well $199-\mathrm{H} 3-3,207 \mathrm{~L} / \mathrm{min}$ in well $199-\mathrm{H} 3-4$, and $218 \mathrm{~L} / \mathrm{min}$ in well 199-H3-5, the buildup measured $0.16 \mathrm{~m}, 0.16 \mathrm{~m}$, and $0.31 \mathrm{~m}$, respectively. The water-level data and the correlation and trend lines used to calculate the drawdown and buildup in the 100-H Area extraction and injection wells are contained in Appendix B, and the results are summarized in Table 2-12. 
2.4.1.2 Monitoring Wells. Thirteen monitoring wells are currently equipped with pressure transducers and data loggers that record hourly water-level measurements to help assess the hydraulic capture and containment of the extraction wells. Nine of the wells monitor the water level in the vicinity of the extraction wells, two wells monitor the water in the vicinity of the injection wells, and two wells are screened in the aquifer below the RUM (which is a separate, lower aquifer).

Wells 199-H4-12B and 199-H4-15B (screened at the bottom of the unconfined aquifer) are located adjacent to extraction wells 199-H4-12A and 199-H4-15A, respectively. Drawdowns in both wells 199-H4-12B and 199-H4-15B were $0.12 \mathrm{~m}$ (Table 2-12).

Wells 199-H4-4 and 199-H4-64 are compliance wells located near the river, between the three near-river extraction wells. Drawdown in these two wells was $0.10 \mathrm{~m}$ and $0.07 \mathrm{~m}$, respectively. Drawdown was $0.16 \mathrm{~m}$ in compliance well $199-\mathrm{H} 4-63$, which is located near the river and south of well 199-H4-11. The remaining compliance well, 199-H4-5, is located between extraction wells 199-H4-12A and 199-H4-15A, about $125 \mathrm{~m}$ from the shoreline. Drawdown in well $199-\mathrm{H} 4-5$ was $0.17 \mathrm{~m}$. Well $199-\mathrm{H} 4-10$ is located near the river, north of extraction well 199-H4-15A; drawdown was $0.03 \mathrm{~m}$. Well 199-H4-8 is located closest to well 199-H4-7, and drawdown measured $0.07 \mathrm{~m}$. Well 199-H3-2B (screened at the bottom of the unconfined aquifer) is located adjacent to the farthest inland extraction well (199-H3-2A), and drawdown measured $0.08 \mathrm{~m}$.

The drawdown measured $0.06 \mathrm{~m}$ in well $199-\mathrm{H} 4-12 \mathrm{C}$, suggesting that the pump-and-treat system was affecting the aquifer below the RUM. Drawdown in the other deep monitoring well (199-H3-2C) was $0.05 \mathrm{~m}$.

Buildup in the two observation wells (199-H4-49 and 199-H5-1A) monitoring the water table near the injection well field measured $0.15 \mathrm{~m}$ and $0.09 \mathrm{~m}$, respectively. The water-level data and the correlation and trend lines used to calculate the drawdown and buildup in the 100-H Area monitoring wells are contained in Appendix B, and the results are summarized in Table 2-13.

\subsubsection{Numerical Modeling}

A steady-state numerical groundwater model (Micro-Fem) was used to estimate and evaluate the hydraulic capture of the pump-and-treat system in the 100-H Area. The model development process used to construct the $100-\mathrm{H}$ Area groundwater model and the modeling objectives, limitations, and assumptions are described in detail in Appendix $\mathrm{K}$.

Flow lines terminating at the extraction wells in Figures 2-13 and 2-14 show the area of the aquifer through which each extraction well removes groundwater and the chromium carried in the water. The total area encompassed by the flow lines terminating at each extraction well represents the capture zone of that extraction well. Flow lines terminating at the river indicate areas where the groundwater passes uncaptured by the extraction wells and discharges into the river. Also shown in the figures is the plume distribution described in Section 2.4.3.1. A comparison of the modeled water levels to the actual water levels measured in November is included in Table 2-12. 
In the 100-H Area, three of the extraction wells are located near the river, and a significant number of flow lines are originating from the river (Figure 2-13). However, most of the water extracted by the near-river extraction wells originates from the inland upgradient area of the aquifer. Pumping in wells 199-H4-7 and 199-H4-65 forces more of the capture to occur laterally around wells 199-H4-11, 199-H4-12A, and 199-H4-15A, and helps to provide additional hydraulic capture in the area between the near-river extraction wells. The capture zone exerted by pumping in well 199-H3-2A extends from the upgradient area west-southwest of the well and down to the injection well field. This extraction well does not appear to contribute to or improve significantly the near-river hydraulic capture.

To assess quantitatively the relative effectiveness of the hydraulic barrier caused by the extraction wells and to identify areas where groundwater may flow through the target area uncaptured to the river, a series of 50 flow lines was added to the capture analysis (Figure 2-14). The flow lines indicate where a particle of water travels in the aquifer and whether the water is captured by the extraction wells or is discharged into the river. The series was placed upgradient of the near-river extraction wells within the area originally defined as the target area of the pump-and-treat system (Figure 3-1 in DOE-RL [1996b]). The extraction wells capture 47 of the 50 flow lines, suggesting that the pump-and-treat system currently captures a similar proportion of the groundwater flowing through approximately $94 \%$ of the target (remediation) area. Most of the uncaptured groundwater that discharges into the river through the target area passes south of well 199-H4-11.

\subsubsection{Contaminant Monitoring}

This section summarizes and interprets the analytical results obtained from groundwater wells included in the interim remedial action and OU monitoring programs supporting the 100-HR-3 pump-and-treat system and OU in the 100-H Area. Data are stored in the Hanford Environmental Information System (HEIS) database or in the project-specific database.

The principal COC in the $100-\mathrm{H}$ Area is hexavalent chromium. Co-contaminants are nitrate, strontium-90, technetium-99, tritium, and uranium. Section 2.4.3.1 discusses the results of chromium monitoring, and Section 2.4.3.2 discusses the results of co-contaminant monitoring. Locations of the monitoring wells and aquifer sampling tubes are shown in Figure 2-3. Chromium, conductivity, and co-contaminant plots are presented in Appendix F.

2.4.3.1 Chromium Monitoring Results. Chromium is monitored throughout the 100-H Area in compliance, extraction, and monitoring wells, and at sample tube locations along the Columbia River. Monitoring is also performed at two riverbank seeps located along the steep slopes adjacent to the river. The number of groundwater monitoring locations and sampling frequencies in the 100-H Area are identified in Table 2-13. Additional groundwater monitoring information for CY 2000 is provided in the Interim Action Monitoring Plan for the 100-HR-3 and 100-KR-4 Operable Units (DOE-RL 1997a). Construction details and the use of each well in the 100-H Area network are presented in Table 2-14. 
Site waste control issues during CY 2000 resulted in adjustments to the scheduled sampling events. These adjustments involved canceling the March and April monthly compliance monitoring events.

Changes in the chromium distribution in groundwater have occurred in the $100-\mathrm{H}$ Area since the baseline chromium plume map was developed in 1995. Figure 2-15 presents the 1995 baseline chromium distribution map and successive maps developed for fall 1998, fall 1999, and fall 2000 chromium concentrations. Previous monitoring results indicate that chromium concentrations are strongly influenced by river stage in the 100-H Area. Therefore, chromium distribution maps are based on fall monitoring results because river levels are generally at a seasonal low and have minimum influence on groundwater conditions during this time period. The water quality data used to develop the fall 2000 chromium distribution include the following:

- November 2000 compliance well and OU monitoring well results

- The average of early November, mid-November, and late November 2000 weekly extraction well monitoring results (collected by the process operator)

- November 2000 sample tube data

- November groundwater seep data.

Due to the proximity of the sample tubes and riverbank seepage to the river, the groundwater quality at these sampling locations generally experiences a greater degree of river influence. Therefore, the sample tube and seep data are considered only qualitatively in developing the fall 2000 chromium distribution map.

Sequential chromium distribution maps shown in Figure 2-15 illustrate the gradual change in concentrations across the 100-H Area. The size of the chromium plume has been reduced over time, and areas of highest concentration appear to have moved downgradient towards the extraction system and the Columbia River. This shift in the chromium distribution pattern is discussed in more detail below.

Average annual chromium concentrations for the years 1997 through 2000 are presented in Table 2-15. The annual averages were developed using the following guidelines: only filtered field testing results were used; duplicate sample results were averaged; laboratory splits were not included; and the detection limit value was used for nondetection results. The short-term and long-term trend results are also presented in Table 2-15. Short-term chromium concentration trends at individual wells were evaluated by comparing the 1999 and 2000 annual averages. Long-term trends in chromium concentration were assessed by comparing CY 1997 data to CY 2000 data (or next closest years). Both short-term and long-term trends were considered stable if the RPD between calendar years was less than 20\%. Chromium concentrations plotted against time are presented in Figure 2-16 and contained in Appendix F.

The following are key items or highlights should be noted regarding chromium in the $100-\mathrm{H}$ Area for 2000. 
- Compliance wells (199-H4-4, 199-H4-5, 199-H4-63, and 199-H4-64). Average annual chromium concentrations in two compliance wells (199-H4-4 and 199-H4-63) were higher than average concentrations in CY 1999, indicating a short-term increasing trend (Table 2-15). The short-term trend in compliance well 199-H4-64 was stable, and hexavalent chromium decreased slightly in well 199-H4-5. The CY 2000 average annual chromium concentrations in these compliance wells were $71.4 \mu \mathrm{g} / \mathrm{L}, 70.3 \mu \mathrm{g} / \mathrm{L}, 59.2 \mu \mathrm{g} / \mathrm{L}$, and $42.2 \mu \mathrm{g} / \mathrm{L}$, respectively. The short-term increase in concentrations may be attributed to lower river levels in the summer and fall of 2000.

In the long-term, chromium concentrations increased and varied seasonally in response to river fluctuations in compliance wells 199-H4-4, 199-H4-63, and 199- H4-64 (Appendix F). The highest chromium concentrations are observed in the late fall (November and December) during the period of lowest river stage (i.e., the period of minimal river influence on groundwater quality). Chromium concentrations have declined in well 199-H4-5 since 1998; the decline may be attributed to the impact of the pump-and-treat system in reducing contaminant mass.

- Extraction wells (199-H3-2A, 199-H4-11, 199-H4-12A, 199-H4-15A, 199-H4-7, and 199-H4-65). The 100-H Area extraction wells exhibited varied short-term trends in average chromium concentrations between 1999 and 2000. Average annual chromium decreased in extraction wells 199-H4-7, 199-H4-11, and 199-H3-2A and remained stable in extraction wells 199-H4-12A and 199-H4-15A (Table 2-15). Average 2000 chromium concentrations in the extraction wells were $8.4 \mu \mathrm{g} / \mathrm{L}, 38.3 \mu \mathrm{g} / \mathrm{L}, 53 \mu \mathrm{g} / \mathrm{L}, 44.9 \mu \mathrm{g} / \mathrm{L}$, and $45.3 \mu \mathrm{g} / \mathrm{L}$, respectively. In the long term, extraction wells 199-H3-2A, 199-H4-7, and 199-H4-11 exhibit a general decreasing trend between 1997 and 2000 (Figure 2-16). Similar to their short-term trends, both extraction wells 199-H4-12A and 199-H4-15A display a relatively stable long-term trend, although well 199-H4-12A exhibits a greater degrec of variability. Monitoring well 199-H4-65 was not evaluated because it was not in service all of CY 2000.

- Monitoring wells. Of the 31 monitoring wells listed in Table 2-15, 13 wells displayed decreasing short-term trends between 1999 and 2000, 14 wells were stable or displayed no trend because of insufficient data, and 4 wells displayed increasing trends. Monitoring wells that displayed annual average increases between 1999 and 2000 were 199-H4-4, 199-H4-49, 199-H4-63, and 199-H5-1A. However, trends in these wells appear to fluctuate throughout time due to river fluctuations.

Long-term chromium trends in monitoring wells are presented as concentration trend plots in Figure 2-16 and Appendix F. Starting in late 1997 and 1998, the majority of 100-H Area monitoring wells exhibit long-term decreasing trends in chromium concentrations. Pumpand-treat operations began in July 1997. Concentration trend plots from inland monitoring wells localed outside the fall $200022-\mu \mathrm{g} / \mathrm{L}$ isopleth all display this characteristic decline, resulting in the reduction in the areal extent of the plume. Many monitoring wells located inside the fall $200022-\mu \mathrm{g} / \mathrm{L}$ and $50-\mu \mathrm{g} / \mathrm{L}$ chromium isopleths also show this declining trend; examples include wells 199-H4-8, 199-H4-17, 199-H4-18, 199-H4-45, and 199-H4-14. This overall chromium concentration reduction along with an increase in chromium in well $199-\mathrm{H} 4-4$ from $42 \mu \mathrm{g} / \mathrm{L}$ in 1999 to $102 \mu \mathrm{g} / \mathrm{L}$ in 2000 suggests that the areas of highest 
chromium concentration have been reduced and shifted closer to the extraction system and river (Figure 2-15).

- Aquifer sampling tubes. Samples were obtained from two aquifer sampling tubes in November 2000 (tubes 46 and 48). Specific conductance was $300 \mu \mathrm{S} / \mathrm{cm}$ in tube 46 and 524 $\mu \mathrm{S} / \mathrm{cm}$ in tube 48 . As shown in Figure 2-15, the aquifer sampling tube chromium concentrations in the 100-H Area support the monitoring and compliance well results. The maximum chromium concentration in a sample collected from a tube along the $100-\mathrm{H}$ Area shoreline was $40 \mu \mathrm{g} / \mathrm{L}$ in tube 48 , a slight decrease from the 1999 concentration of $45 \mu \mathrm{g} / \mathrm{L}$ in the same sample tube.

- Groundwater Seeps (150-1 and 153-1). Samples were collected from riverbank seeps 150-1 and 153-1 on October 17, 2000. As shown in Figure 2-15, chromium concentrations were $6 \mu \mathrm{g} / \mathrm{L}$ and $<4.1 \mu \mathrm{g} / \mathrm{L}$ (nondetected), respectively. These results are below the remediation goal of $22 \mu \mathrm{g} / \mathrm{L}$.

2.4.3.2 Co-Contaminant Monitoring Results. Co-contaminants in the 100-H Area consist of strontium-90, technetium-99, tritium, uranium, and nitrate (DOE-RL 1996b). Table 2-16 presents the average annual co-contaminant concentrations and short-term concentration trends where they could be developed. The results of the co-contaminant monitoring for 2000 are summarized as follows:

- Strontium-90. Average annual strontium-90 activities in 100-H Area wells generally remained stable or decreased between 1999 and 2000. The single exception was the increasing trend observed in well 199-H4-18 where average activity increased from $3.37 \mathrm{pCi} / \mathrm{L}$ in 1999 to $5.13 \mathrm{pCi} / \mathrm{L}$ in 2000 . The MCL for strontium- 90 is $8 \mathrm{pCi} / \mathrm{L}$.

- Technetium-99. With the exception of four extraction wells, annual average technetium-99 activities exhibited short-term decreasing trends or remained stable. Extraction wells 199-H3-2A, 199-H4-11, 199-H4-15, and 199-H4-7 exhibited increasing trends between 1999 and 2000. However, the maximum technetium-99 value in any 100-H Area wells during CY 2000 was $239.3 \mathrm{pCi} / \mathrm{L}$ in monitoring well 199-H4-4. The EPA drinking water standard for technetium-99 is $900 \mathrm{pCi} / \mathrm{L}$.

- Tritium. Average annual tritium activity in well 199-H4-4 increased from $1,140 \mathrm{pCi} / \mathrm{L}$ in 1999 to $2,070 \mathrm{pCi} / \mathrm{L}$ in 2000 . The remaining wells tested for tritium displayed stable or decreasing short-term trends. The EPA drinking water standard for tritium is $20,000 \mathrm{pCi} / \mathrm{L}$.

- Uranium and Nitrate. The average annual uranium and nitrate concentrations in extraction well 199-H4-12A increased between 1999 and 2000. Other wells tested in the 100-H Area exhibited stable or decreasing trends for uranium and nitrate. Five wells contained nitrate above the $45 \mathrm{mg} / \mathrm{L} \mathrm{MCL}$, and trends were decreasing or stable in each well. Only well 199-H4-4 contained total uranium above the $20 \mu \mathrm{g} / \mathrm{L}$ MCL, and the concentration in this well was approximately $23 \mu \mathrm{g} / \mathrm{L}$ and stable. 


\subsection{QUALITY ASSURANCE/QUALITY CONTROL FOR 100-D AND 100-H MONITORING DATA}

Quality control data from the CY 2000 100-D and 100-H Area sampling events are presented in Table 2-17 and include field replicates, field/offsite laboratory splits, and offsite laboratory splits. The RPDs, also shown in Table 2-17, for each set of QC data were determined using the following equation:

$$
\operatorname{RPD}=\frac{\left(\mathrm{C}_{1}-\mathrm{C}_{2}\right) \times 100 \%}{\left(\mathrm{C}_{1}+\mathrm{C}_{2}\right) / 2}
$$

where $C_{1}$ and $C_{2}$ are the observed concentrations or activities from the samples; unless otherwise noted, $\mathrm{C}_{1}$ is the larger of the two observed concentrations. The RPD was not calculated if one of the results included a "U" qualifier.

The RPDs for 17 pairs of field replicates were analyzed for hexavalent chromium. The RPD for the field replicates generally ranged from $0 \%$ to $6 \%$; however, one data pair had an RPD of $24 \%$. The EPA functional guidelines are $\pm 20 \%$ for these types of analyses; therefore, only 1 of the 17 samples was outside of this guideline (Bleyler 1988).

The RPDs for nine split sample pairs analyzed for hexavalent chromium in both the field and laboratory were determined for the purpose of comparing the field measurements with analytical laboratory measurements. The RPD was calculated by subtracting the field value from the corresponding laboratory value and dividing by the average of the two values. Negative RPDs for the split samples indicate a bias toward higher field values than laboratory values.

The RPDs for the split samples were all negative and ranged from less than $-2 \%$ to over $-66 \%$ : four of the splits were between $-31 \%$ and $-66 \%$, three ranged from $-9 \%$ to $-16 \%$, and two of the RPDs for the split samples ranged from $-2 \%$ to $-1 \%$. The bias toward higher field values is reasonable when the inherent instability of hexavalent chromium is considered, as well as the longer holding times associated with a laboratory analysis versus a field analysis.

A second series of split samples was obtained during the sampling events and sent to offsite laboratories for analysis of total chromium, technetium-99, and uranium. The purpose for these samples was to audit the precision of the analytical laboratory analyses. The RPDs for the total chromium analysis ranged from $0 \%$ to $24 \%$ : only one of the RPDs was over $20 \%$, six of the RPDs ranged from $8 \%$ to $15 \%$, and two of the RPDs were less than $3 \%$. The results of the technetium-99 analysis were below detection limits for both samples, and therefore no RPD was calculated for this split. The RPD for the uranium analyses was zero. With the exception of the $24 \%$ RPD for one of the total chromium splits, the data indicate the laboratories were performing within the project QA requirements of 20\% (DOE-RL 1997a). 


\section{$2.6 \quad$ 100-HR-3 CONCLUSIONS}

Measurable progress was made toward meeting the specific RAOs for the 100-HR-3 OU pumpand-treat interim action operation for the period of January 1, 2000, through December 31, 2000. Each of the RAOs is discussed below.

- RAO \#1: Protection of aquatic receptors in the river bottom substrate from contaminants in groundwater entering the Columbia River.

Result: Extraction wells in the 100-D and 100-H Areas are reducing chromium mass flux to the Columbia River and thereby protecting aquatic receptors. This conclusion is based on field data, operational data, and groundwater monitoring results.

\section{0-D Area}

- During CY 2000, 135.7 million L of hexavalent chromium was treated and $25.3 \mathrm{~kg}$ removed.

- Numerical modeling suggests that the pump-and-treat captures approximately $84 \%$ of the ground flowing through the target areas. The ERC is evaluating an expansion of the 100-D Pump-and-Treat to capture a high-concentration area located south of the target area as a part of the response to findings of the CERCLA 5-year review by the EPA.

- Average annual chromium concentrations in the 100-D Area compliance wells (199-D8-68, 199-D8-69, 199-D8-70) were higher than the average for the previous year and exceed the remedial action objective of $22 \mu \mathrm{g} / \mathrm{L}$. The short-term increase in concentrations may be attributed to lower river levels in the summer and fall of 2000 .

- Increasing chromium concentrations in a number of the northeastern plume perimeter wells in 2000 suggest that the chromium plume has expanded slightly.

- Co-contaminant data for strontium-90, tritium, nitrate, and sulfate indicated localized increasing trends when compared to previous results.

- No stratification or layering of chromium contamination was observed in CY 2000.

\section{0-H Area}

- During CY 2000, 169.4 million L of hexavalent chromium was treated and $4.7 \mathrm{~kg}$ removed.

- Numerical modeling suggests that the pump-and-treat system captures approximately $90 \%$ of the groundwater flowing through the target area.

- Average annual chromium concentrations in five 100-H Area compliance wells (199-H-4, 199-H-5, 199-H-63, 199-H-4, and 199-H-64) were higher than CY 1999 concentrations and 
exceed the RAO $(22 \mu \mathrm{g} / \mathrm{L})$. These values were $71.4 \mu \mathrm{g} / \mathrm{L}, 70.3 \mu \mathrm{g} / \mathrm{L}, 59.2 \mu \mathrm{g} / \mathrm{L}$, and $42.2 \mu \mathrm{g} / \mathrm{L}$, respectively. The short-term increase may be attributed to lower river stage.

- Of 31 monitoring wells sampled, 13 trends were decreasing, 14 trends were stable, and 4 trends were increasing. The data suggest that highest chromium concentrations have been reduced and shifted closer to the extraction system.

- Co-contaminants data for strontium-90 and technetium-99 indicate decreasing versus stable trends with the exception of the extraction wells. One well had an increasing tritium trend, and the other $100-\mathrm{H}$ wells were stable or decreasing. Extraction well 199-H4-12A had increasing uranium and nitrate trends, and the other 100- $\mathrm{H}$ Area wells were stable or decreasing.

- Overall, the distribution pattern for and high-concentration areas of chromium have significantly diminished since CY 1998. This may be attributed to the effects of the remediation efforts at the $100-\mathrm{H}$ Area.

- RAO \#2: Protection of human health by preventing exposure to contaminants in the groundwater.

Result: Institutional controls were maintained to prevent public access to groundwater.

- RAO \#3: Provide information that will lead to the final remedy.

Result: The following information will be used in determining the final remedy:

Treatment Cost: Treatment cost for the period was $\$ 2,202,500$. At a yearly production rate of 305 million $\mathrm{L}$ and $30 \mathrm{~kg}$ of chromium removed, the treatment cost equates to about $0.7 \notin / \mathrm{L}$, or $\$ 74 / \mathrm{g}$ of chromium removed.

System Efficiency: Removal efficiency of the treatment system was $93.4 \%$.

Hydraulic Impact: Numerical modeling was used to quantify the effectiveness of the capture and containment of the pump-and-treat system. The model suggests that the 100-D Area system captures groundwater from an estimated $84 \%$ of the targeted area that would otherwise discharge into the Columbia River. At the 100-H Area, the model suggests that the system captures groundwater from an estimated $94 \%$ of the targeted area that would otherwise discharge into the Columbia River.

Effectiveness of Contaminant Removal in Aquifer: During this reporting period, more than 305 million L of water was treated from the 100-HR-3 OU, which resulted in the removal of $30 \mathrm{~kg}$ of chromium. Since initiation of the system in July 1997 , more than 959 million L of water has been treated, resulting in the removal of approximately $103.1 \mathrm{~kg}$ of chromium from the 100-HR-3 aquifer. 
Maintain Data: Pertinent data have been maintained in the HEIS database and in the projectspecific database.

System Availability: Overall system availability for the reporting period exceeded $97 \%$, up from $89 \%$ in CY 1999. System availability is a ratio of the actual operating time to the total operating time available. Downtime includes scheduled and unscheduled maintenance; system modifications; and outages associated with weather, power loss, and other acts of nature.

\subsubsection{0-HR-3 Operational Performance}

Progress toward meeting the specific operational performance criterion for the $100-\mathrm{HR}-3 \mathrm{OU}$ pump-and-treat operations is summarized in Table 2-18.

\subsubsection{0-HR-3 Aquifer Performance}

Progress toward meeting the specific aquifer performance criterion for the 100-HR-3 pump-andtreat operations is summarized in Table 2-19.

\subsection{ISSUES FOR FURTHER EVALUATION AT THE 100-HR-3 OU}

- Evaluate the need for estimates of the hexavalent chromium mass in the aquifer in the targeted area, and estimate the time required for the current pump-and-treat system to achieve the compliance level of $22 \mu \mathrm{g} / \mathrm{L}$ specified in the interim remedial action ROD (EPA 1996).

- Evaluate the need for an additional monitoring well in the 100-D Area, downstream from monitoring well 199-D8-70. In this area, the northeasterly extent of the chromium plume is defined only by aquifer sampling tube data. Monitoring wells in this area are characterized by increasing chromium, suggesting that the plume is expanding in this direction slightly.

- Evaluate the need to refine conceptual model that describes the pathway from the groundwater contaminant plume to receptors in the riparian zone and Columbia River substrate.

- Reduce the monitoring frequency for chromium at the compliance wells from 12 to 6 times per year. This frequency is adequate to capture contaminant trends and distinguish these trends from seasonal trends.

- Replace the depth-discrete sampling device at well 199-D8-70 with a regular sample pump because chromium appears to be uniformly distributed in vertical profiling results (i.e., no distinguishable variation).

- Reduce the frequency of influent, effluent, and extraction well confirmation sampling for chromium from quarterly to semi-annually. 


\subsection{RECOMMENDATIONS FOR THE 100-HR-3 OU SYSTEM}

The following are recommended actions for the 100-HR-3 OU treatment system based on operational performance and aquifer response during the reporting period:

- The flow rates and injection rates for the 100-HR-3 pump-and-treat system should be maintained according to the rates identified in the previous annual progress and performance evaluation report (DOE-RL 2000a).

- To improve capture at the 100-D Area, wells 199-D8-68 and 199-D8-6 should be reconfigured as extraction wells at these locations to provide capture of the highconcentration area located south of the target area of the current pump-and-treat system. Upgrades to handle additional treatment capacity include larger volume feeder pond transfer pumps. Planning for this upgrade is under way in response to findings of the CERCLA 5-year review by the EPA. 
Figure 2-1. 100-HR-3 Operable Unit Pump-and-Treat System Layout.

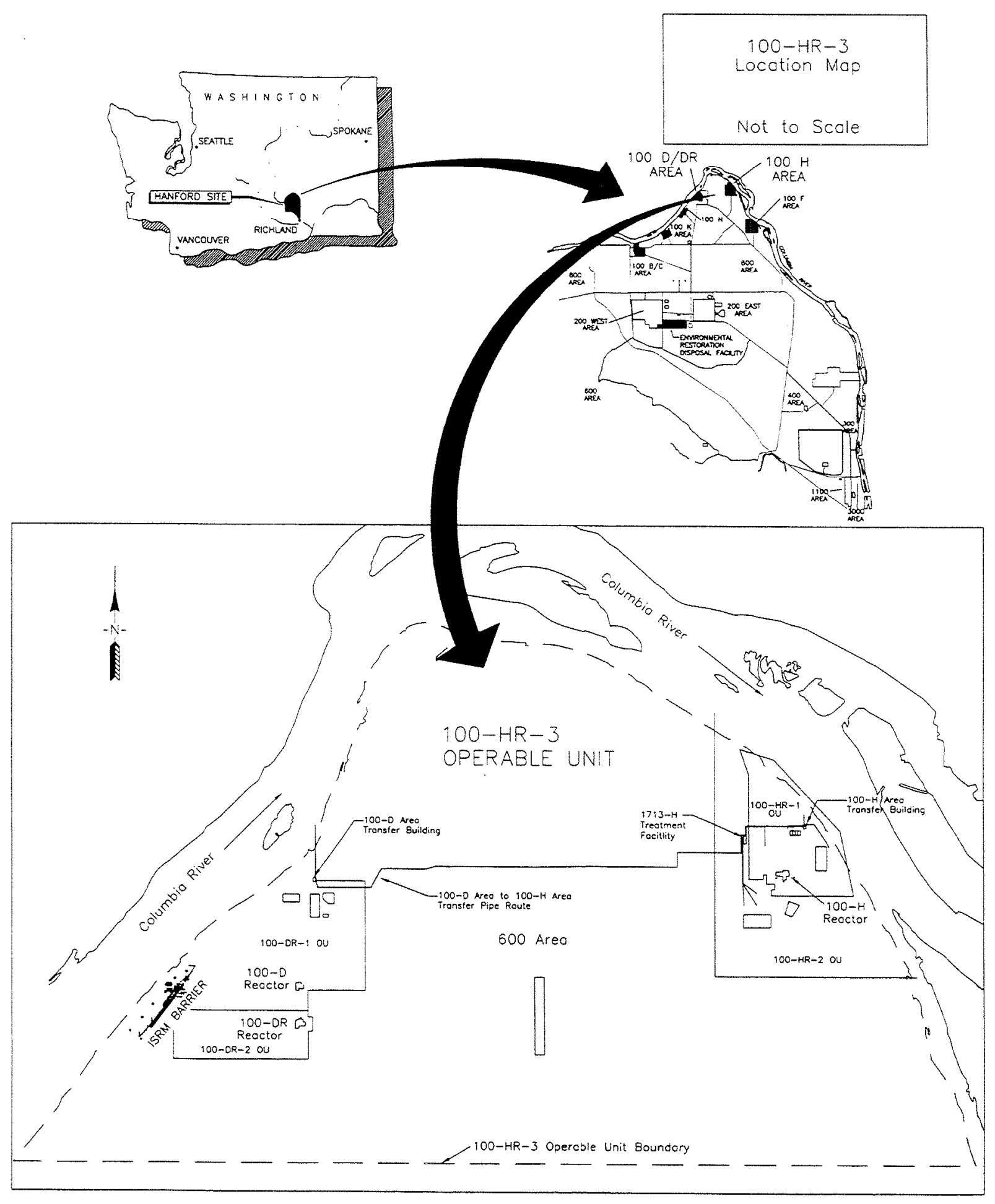

1H:0113998.DWG 

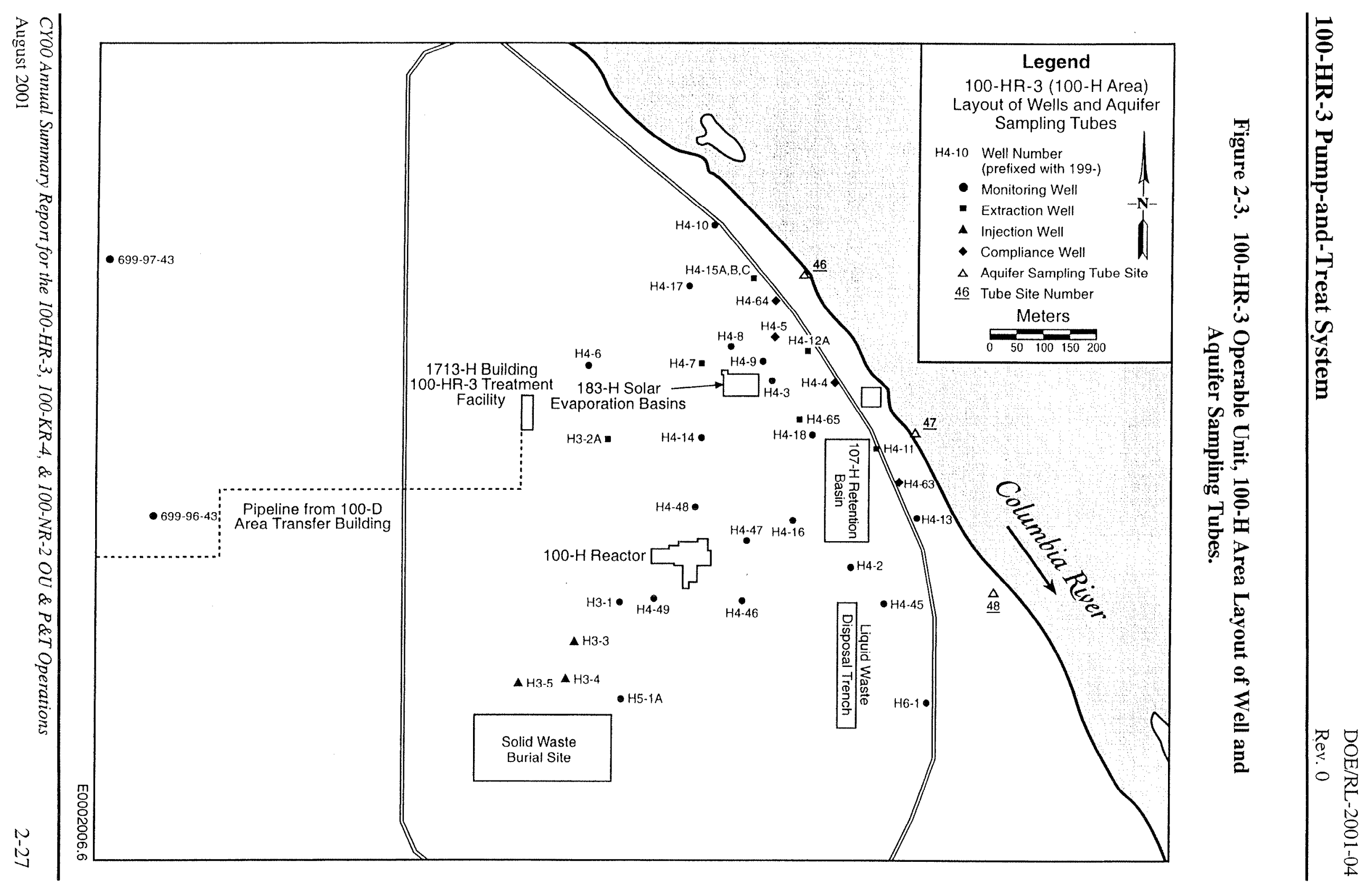
Figure 2-4. 100-HR-3 Operable Unit Pump-and-Treat System Schematic.

\begin{tabular}{|c|}
\hline Legend \\
\hline 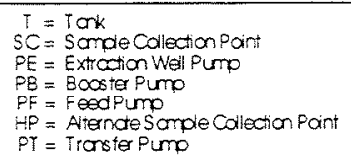 \\
\hline
\end{tabular}

100-HR-3
Pump and Treat System
Schematic
Not to Scale

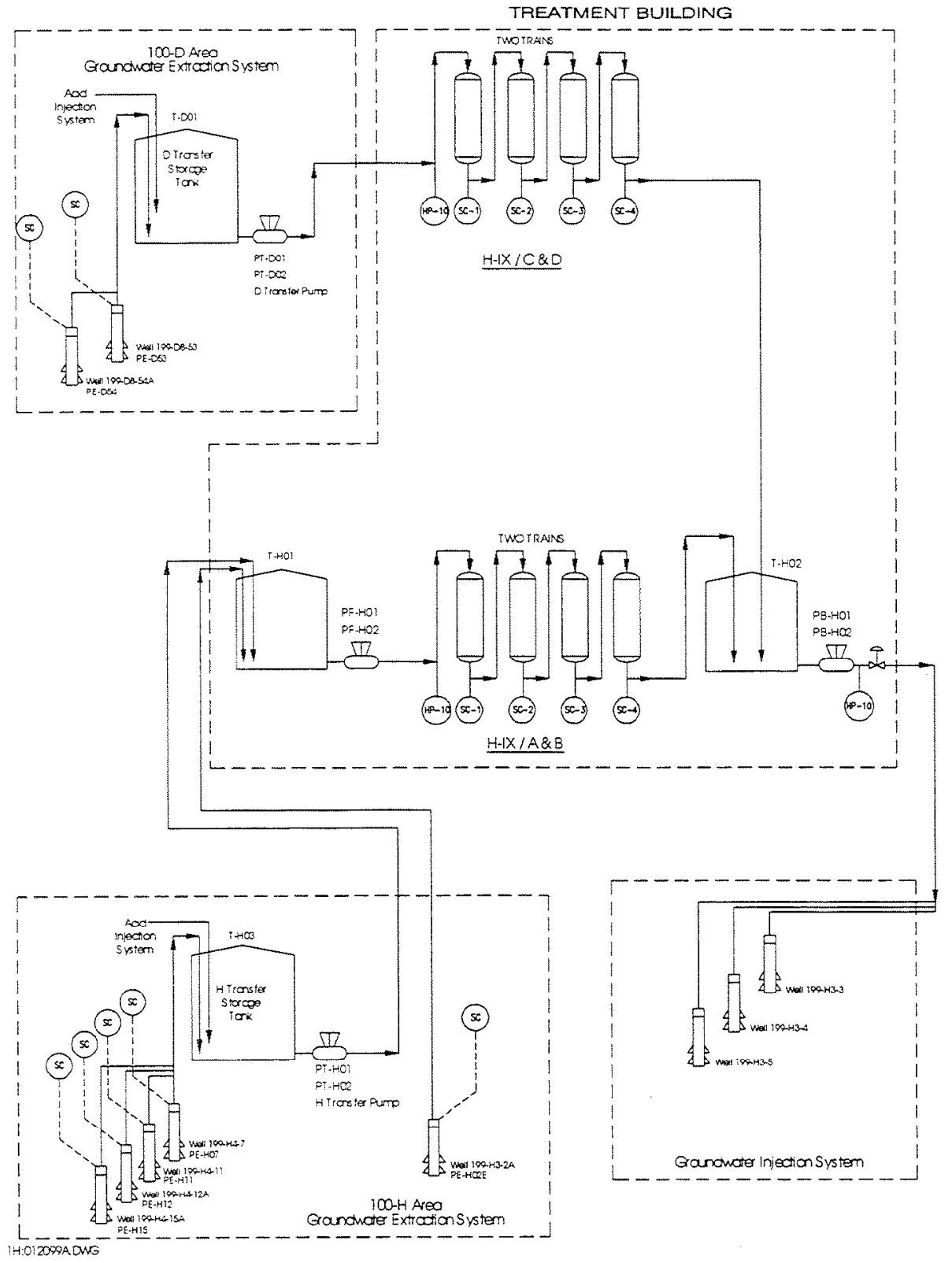


Figure 2-5. 100-HR-3 Trends of Influent and Effluent Hexavalent Chromium Concentrations.

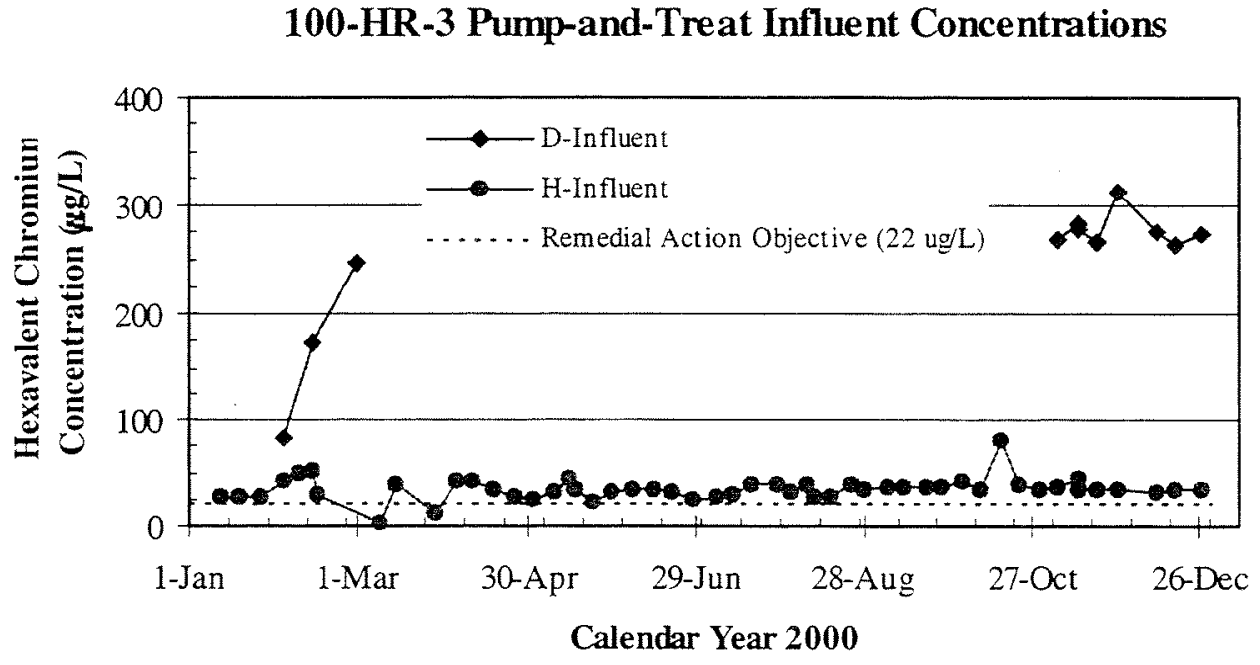

100-HR-3 Pump-and-Treat Effluent Concentrations

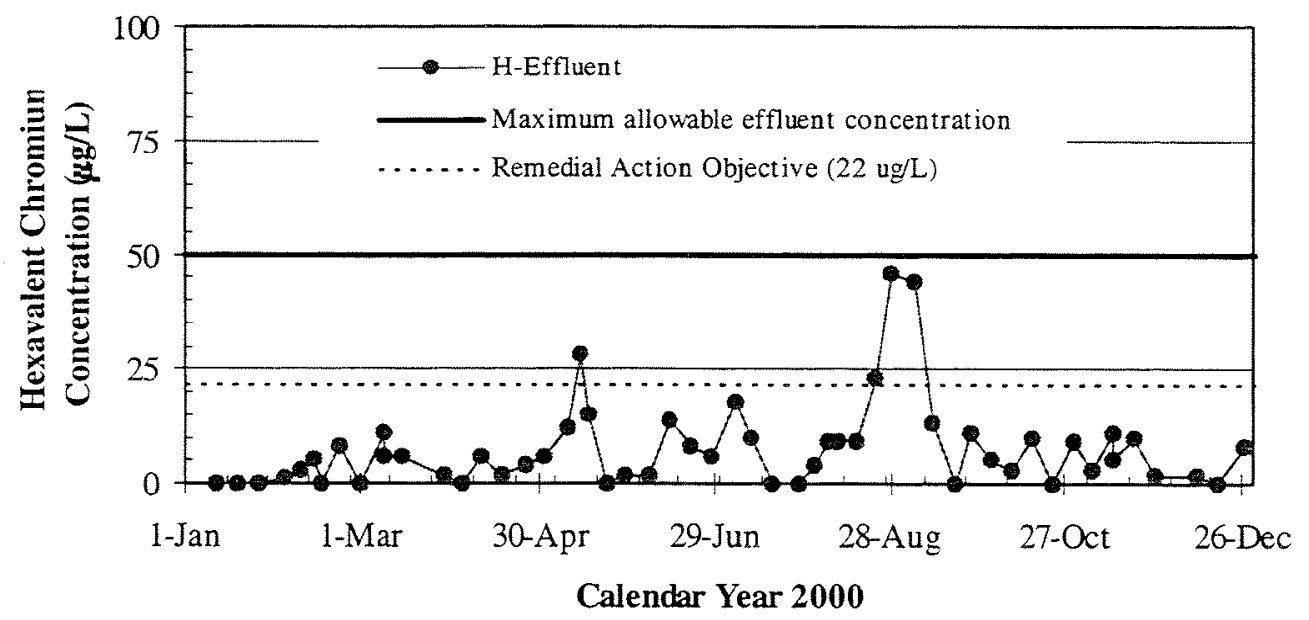


Figure 2-6. 100-HR-3 Pump-and-Treat Trends of Average Removal Efficiencies.

Removal Efficiency of the 100-HR-3 Pump-and-Treat System

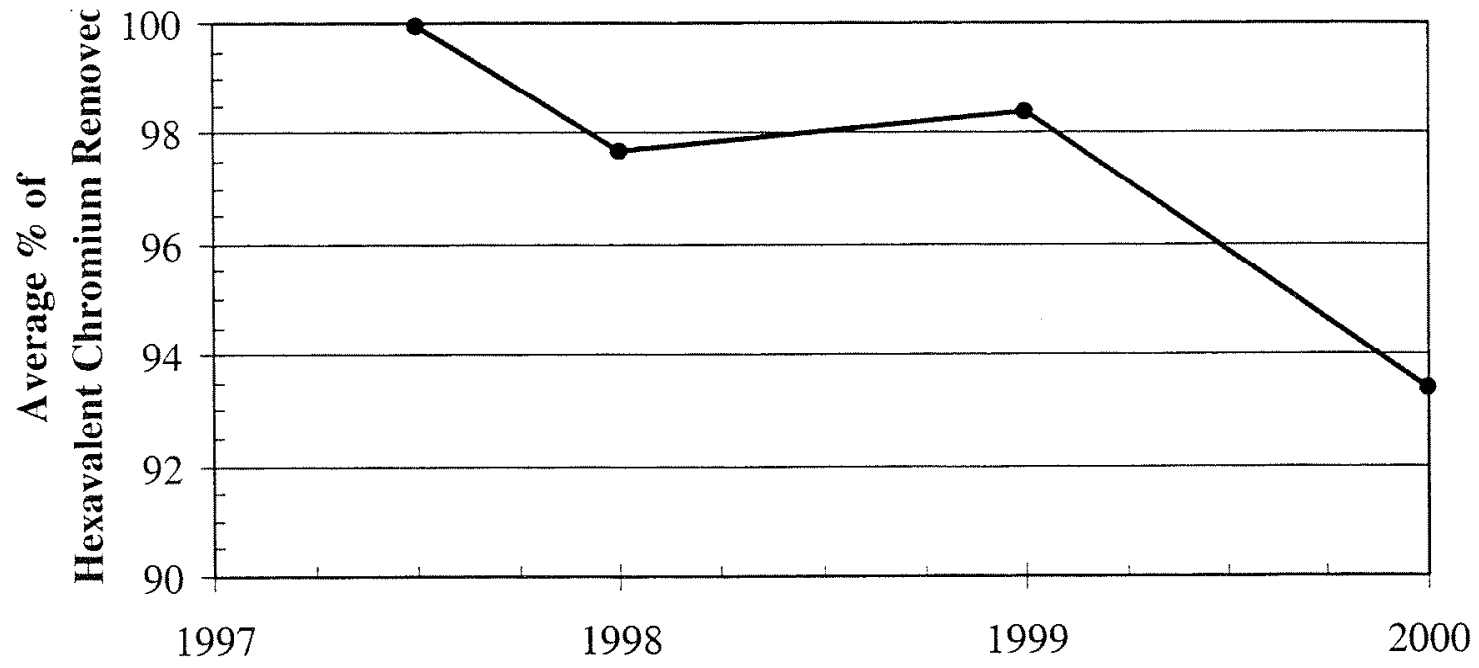

Calendar Year

Note: Decrease in removal efficiency in CY 2000 can be attributcd to a brief period of improper vessel alignment. 
Figure 2-7. 100-HR-3 System Availability and On-Line Percentages.

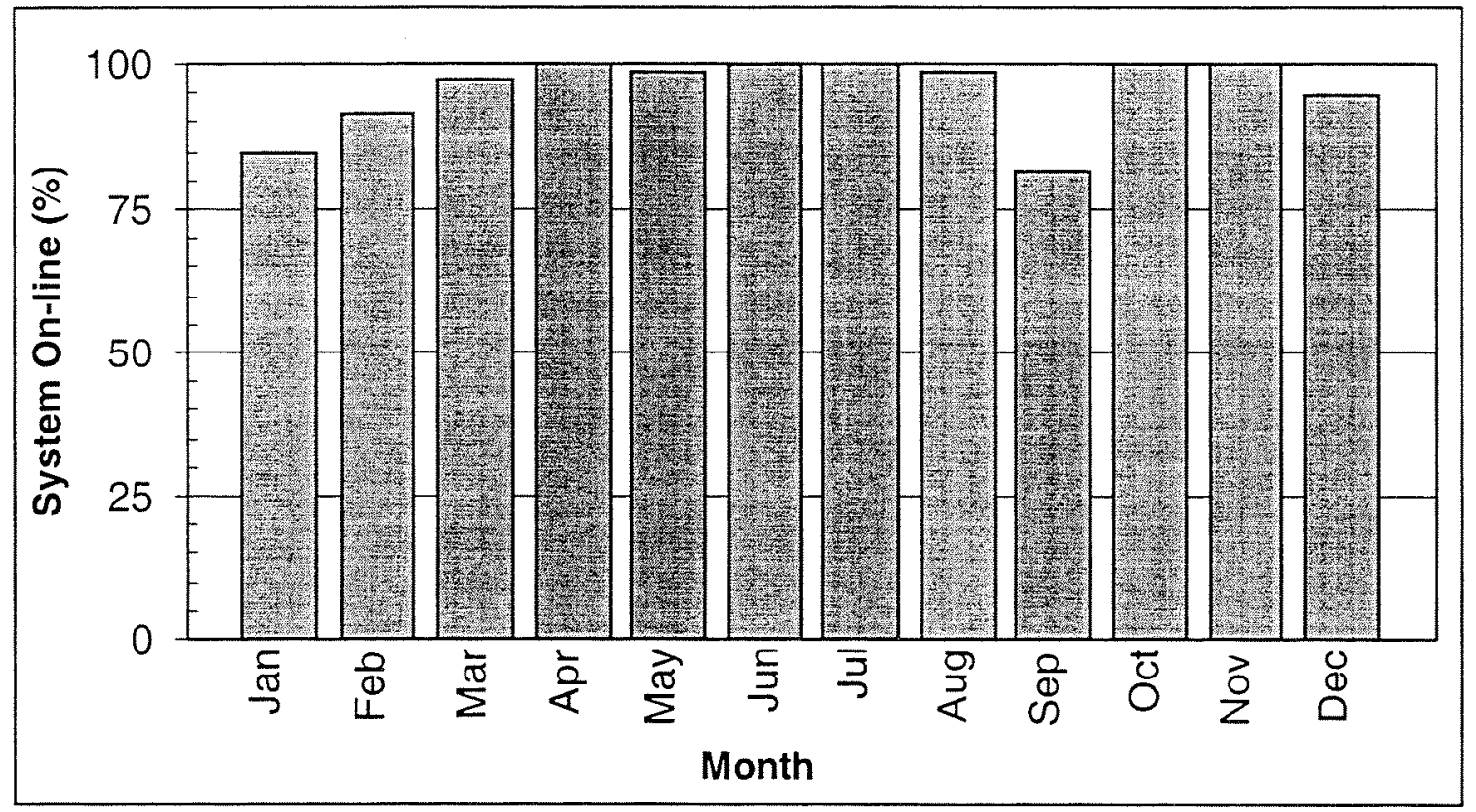

Total time on-line during CY 2000: $8,396.9$ hours

Total time hours during CY 2000: 8,784 hours

Total time available during CY 2000 minus scheduled outages: $8,626.9$ hours

System on-line availability (not including scheduled outages): $95.6 \%$

Total system availability (including scheduled outages): $97.3 \%$

\section{Significant outages included the following:}

- January 1-5: Off-line for a scheduled outage for the year 2000 rollover.

- January 24: Off-line because of a high effluent differential pressure across PDIS-13-BH02B.

- February 19-21: Off-line because of a power outage due to a broken transformer.

- March 29-30: Off-line to support the repair of line 138-KV for the 100 Areas.

- May 25-26: Off-line due to high differential pressure.

- August 4: Off-line because of power outage at 100-N, which happened as a result of a vehicle crash into a power pole.

- September 3: Off-line for an unscheduled outage. Booster pump H01 was tripped.

- September 4-5: Off-line due to unknown causes, possible AFD failure.

- September 9-11: Off-line due to unknown causes, possible AFD failure.

- September 14: Off-line for a scheduled replacement of faulty power supply in PLC.

- September 22: Off-line due to high wind gusts short circuiting the main power distribution lines.

- September 24-25: Off-line because of a faulty level transducer in well 199-H3-5.

- December 2-4: Off-line because of a power outage in the 100 Areas.

- December 5: Off-line to perform modifications to the electrical panel for the new acid automation system. 
Figure 2-8. 100-HR-3 Hexavalent Chromium Concentrations Comparison of Technician Versus Operator Data and the Relative Percent Difference.

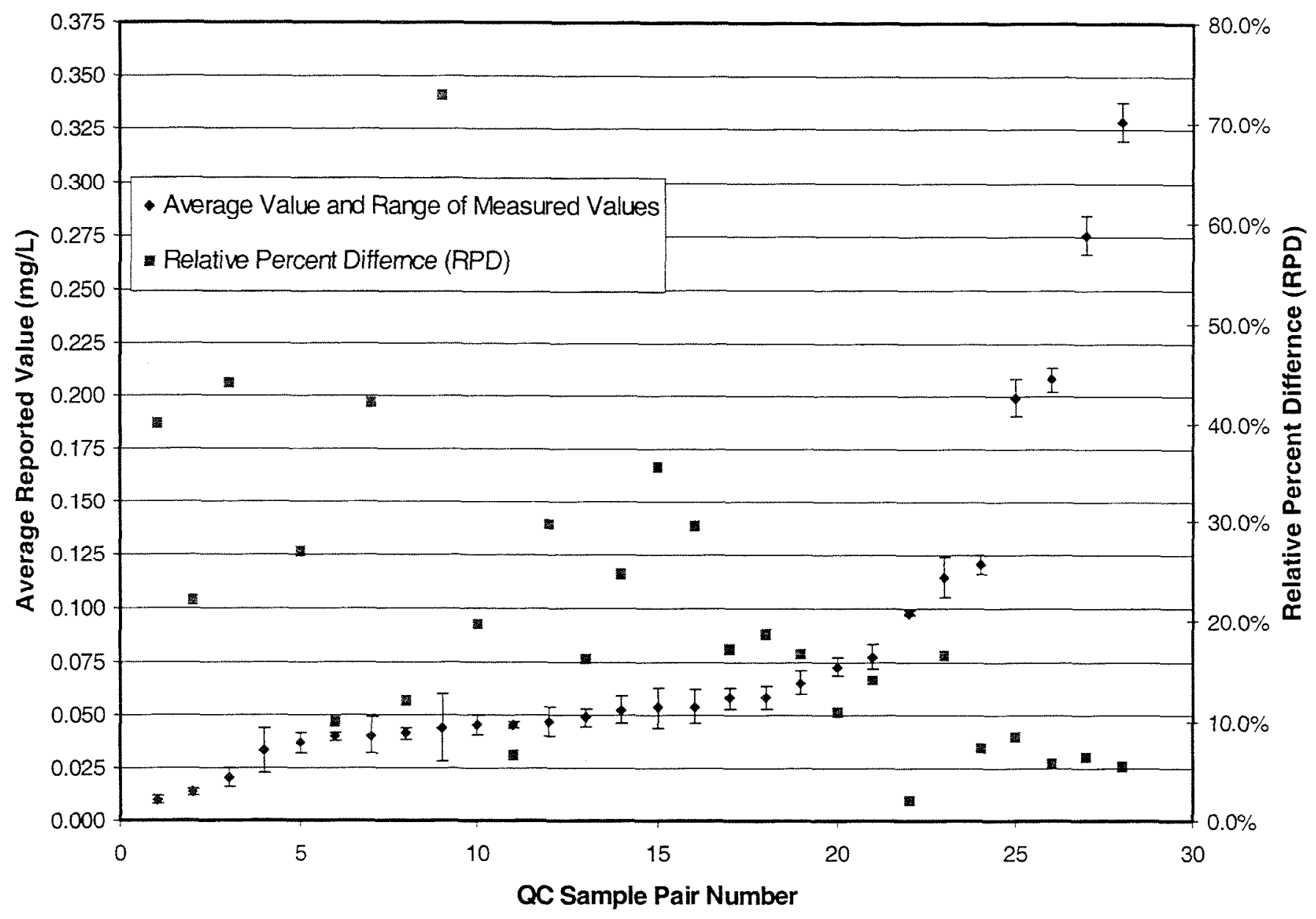




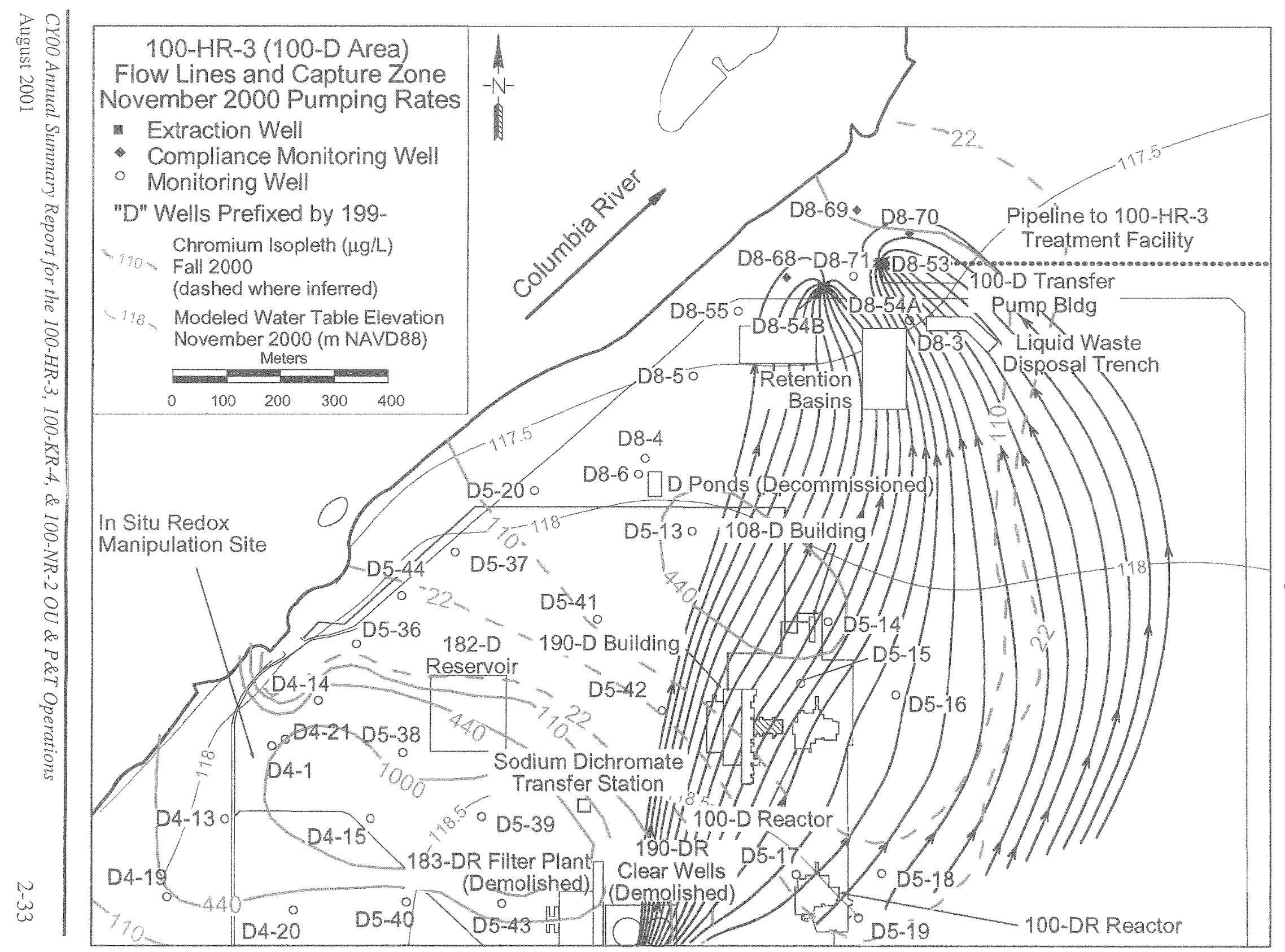

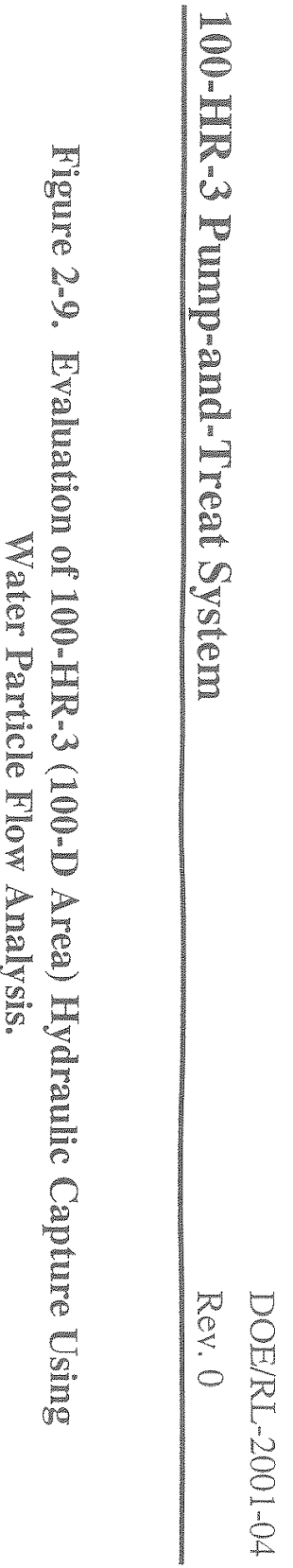




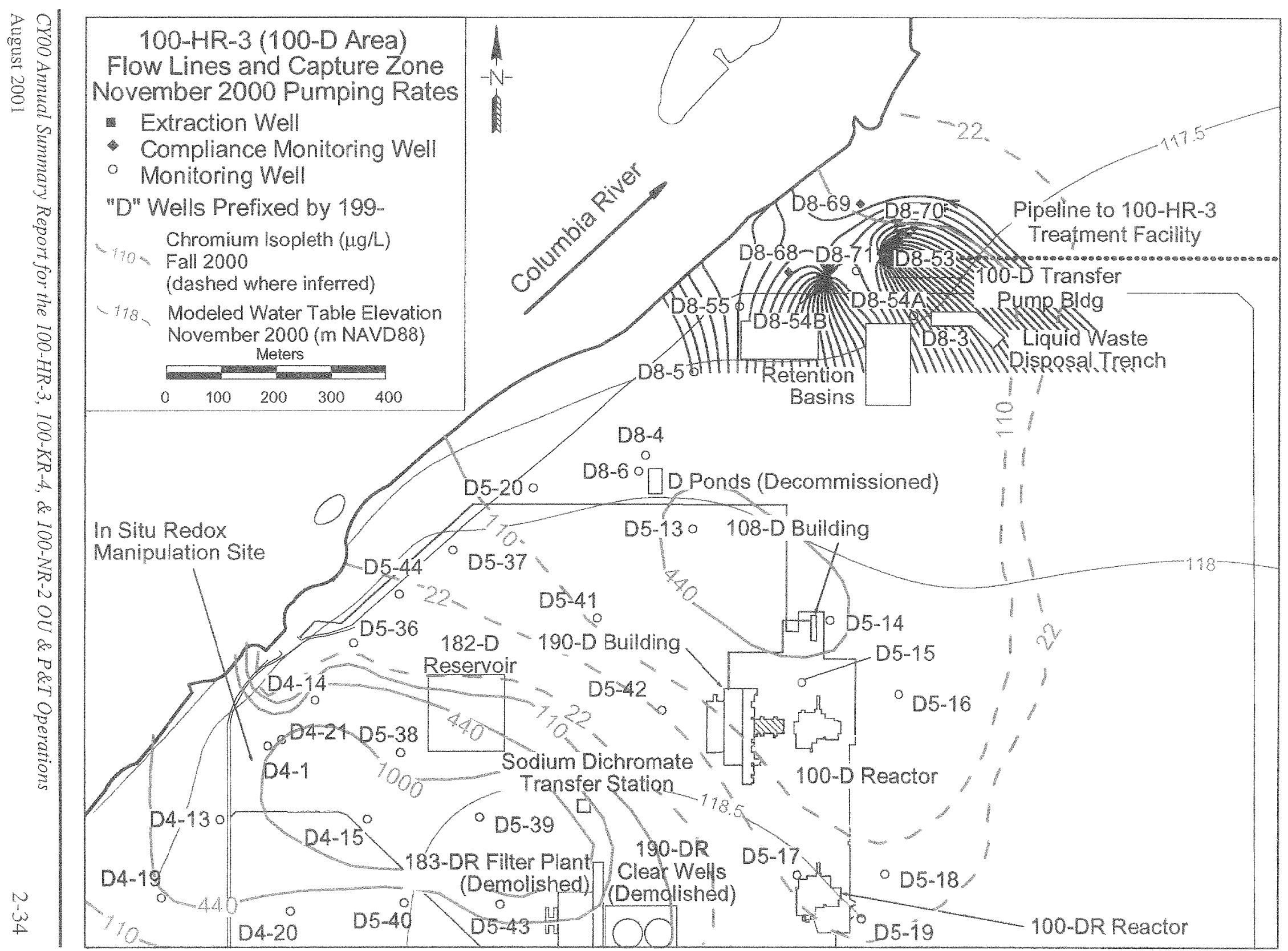

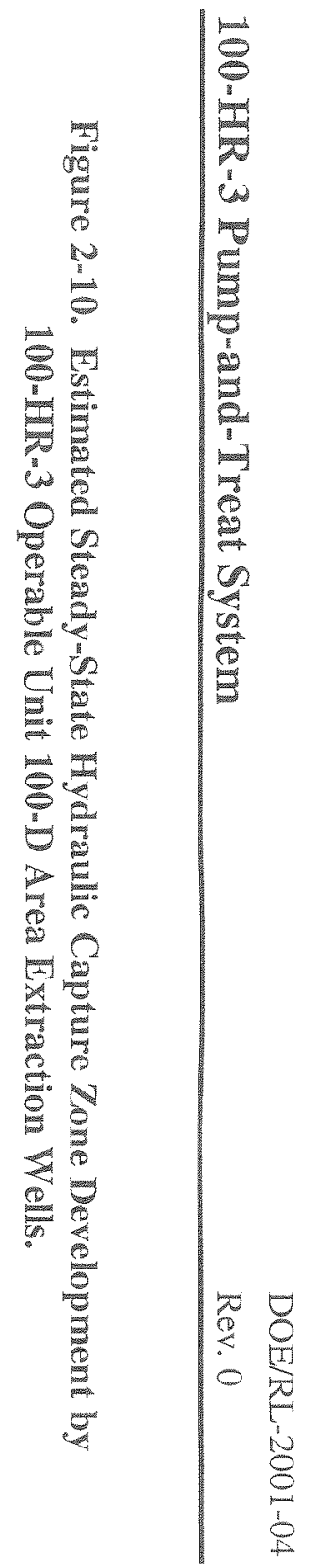


Figure 2-11. 100-D Area Historic Chromium Distribution.
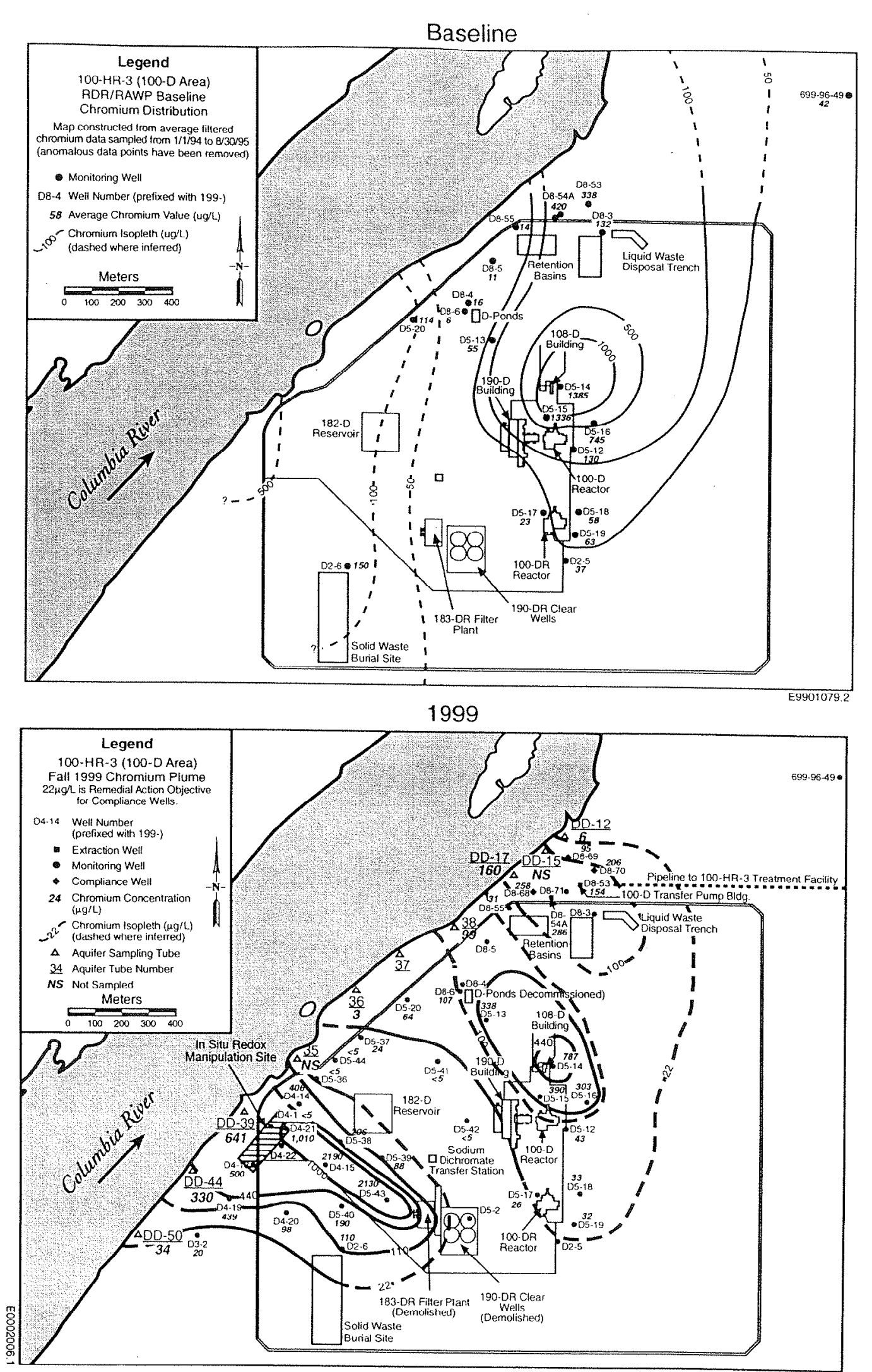
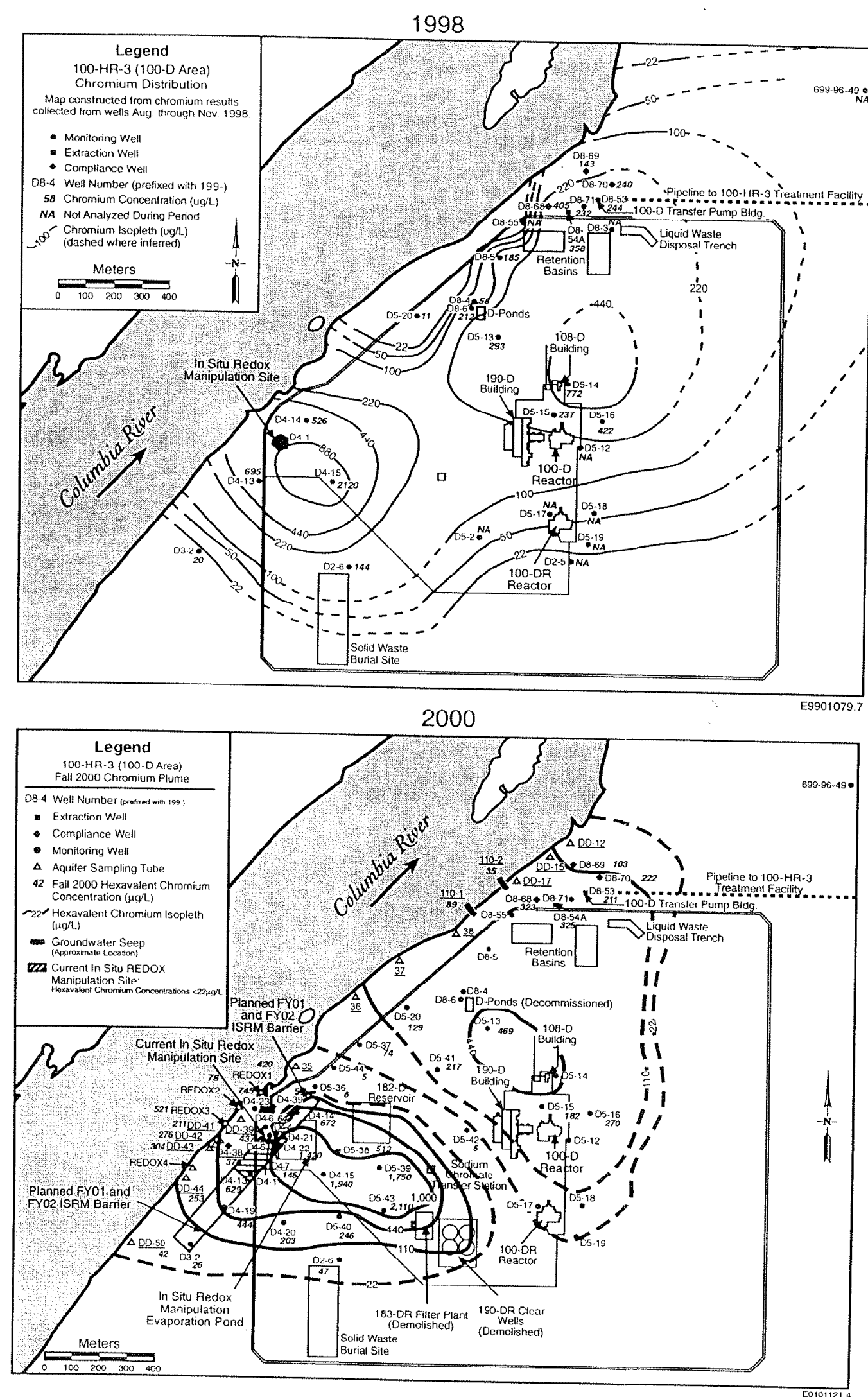
Figure 2-12. 100-HR-3 (100-D Area) Hexavalent Chromium Plume and Trend Plots.

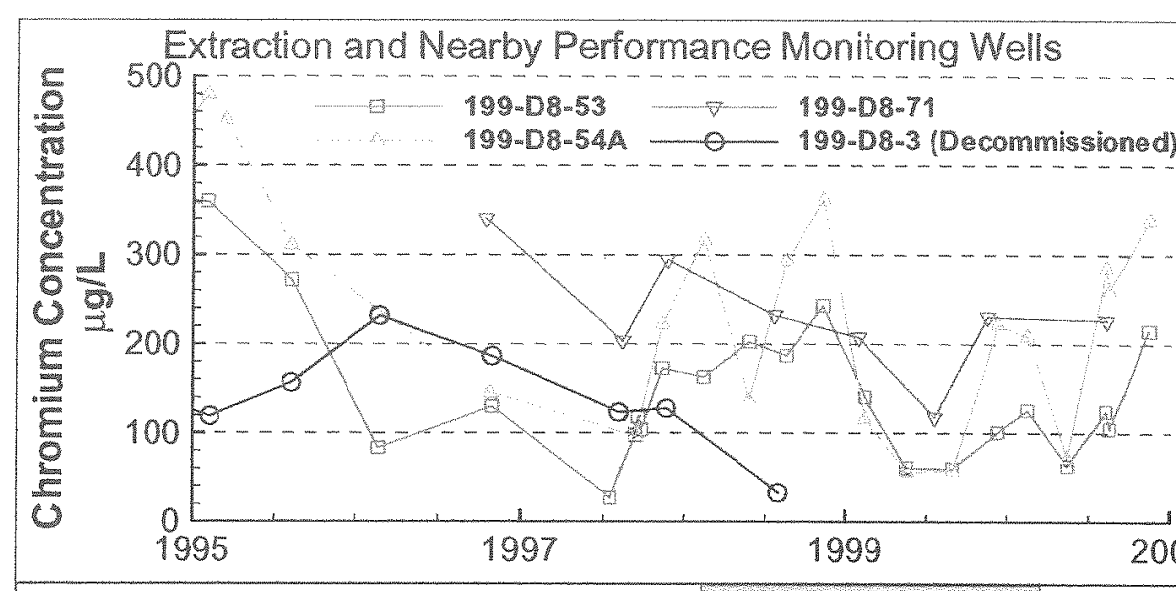

100-HR-3 (100-D Area) November 2000

- Extraction Well

- Compliance Monitoring Well

Monitoring Well

"D" Wells Prefixed by 199 Chromium Isopleth ( $\mu \mathrm{g} / \mathrm{L})$ Fall 2000

(dashed where inferred)

Modeled Water Table Elevation

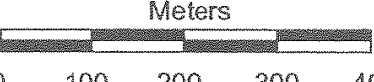

$\begin{array}{llll}100 & 200 \quad 300 \quad 400\end{array}$
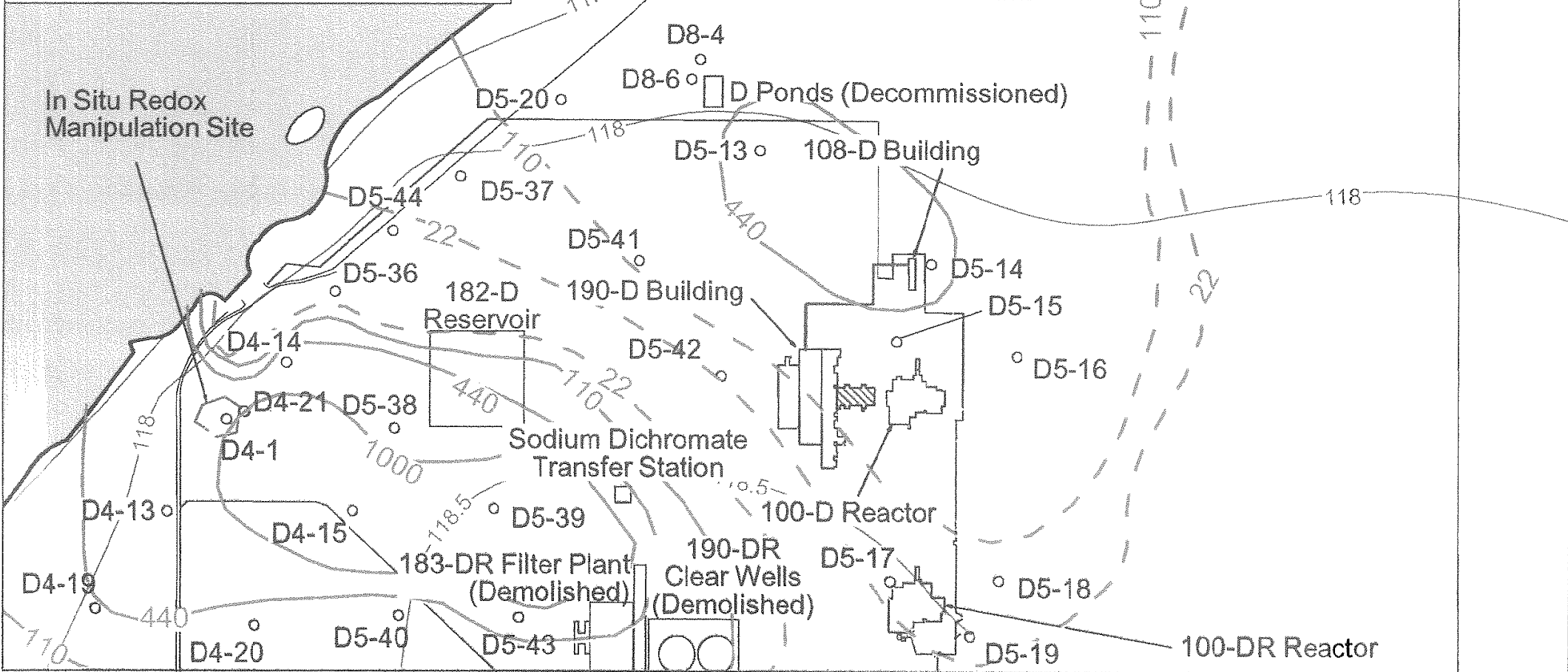

Near River Monitoring Wells

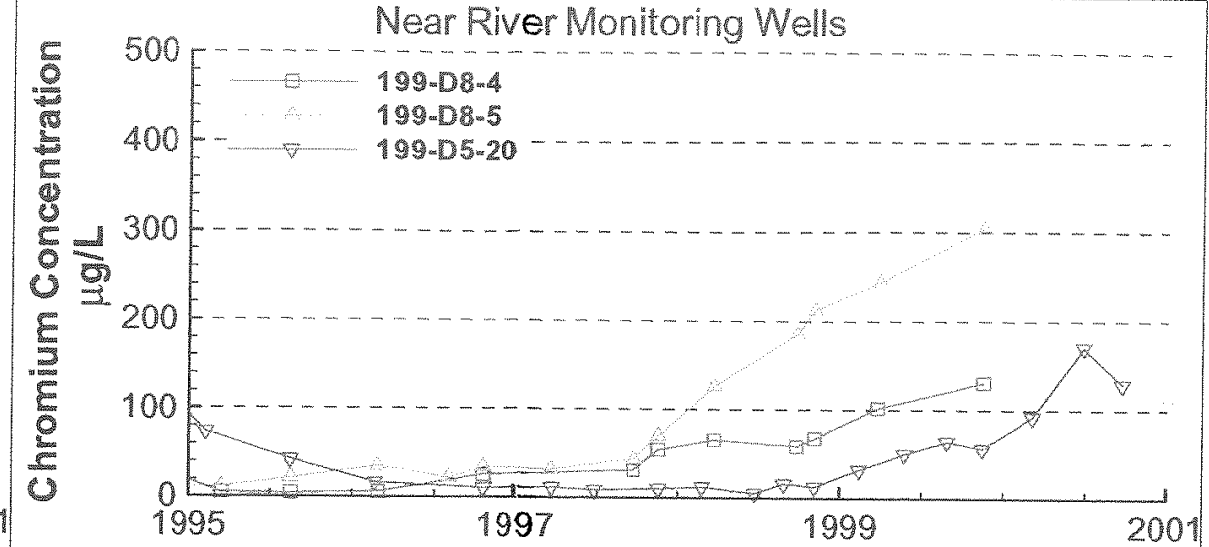

1997

$\frac{1999}{199}$ 200
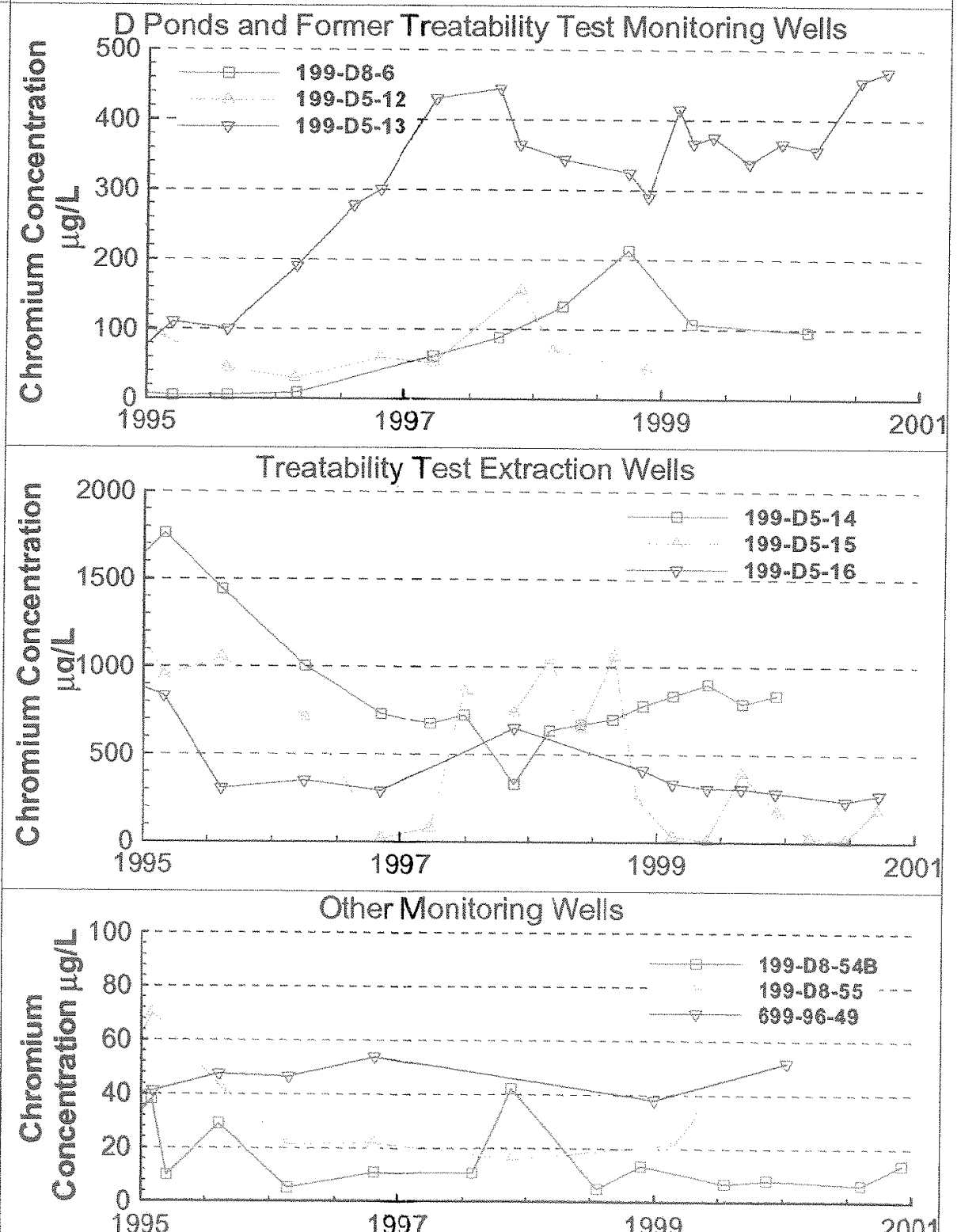


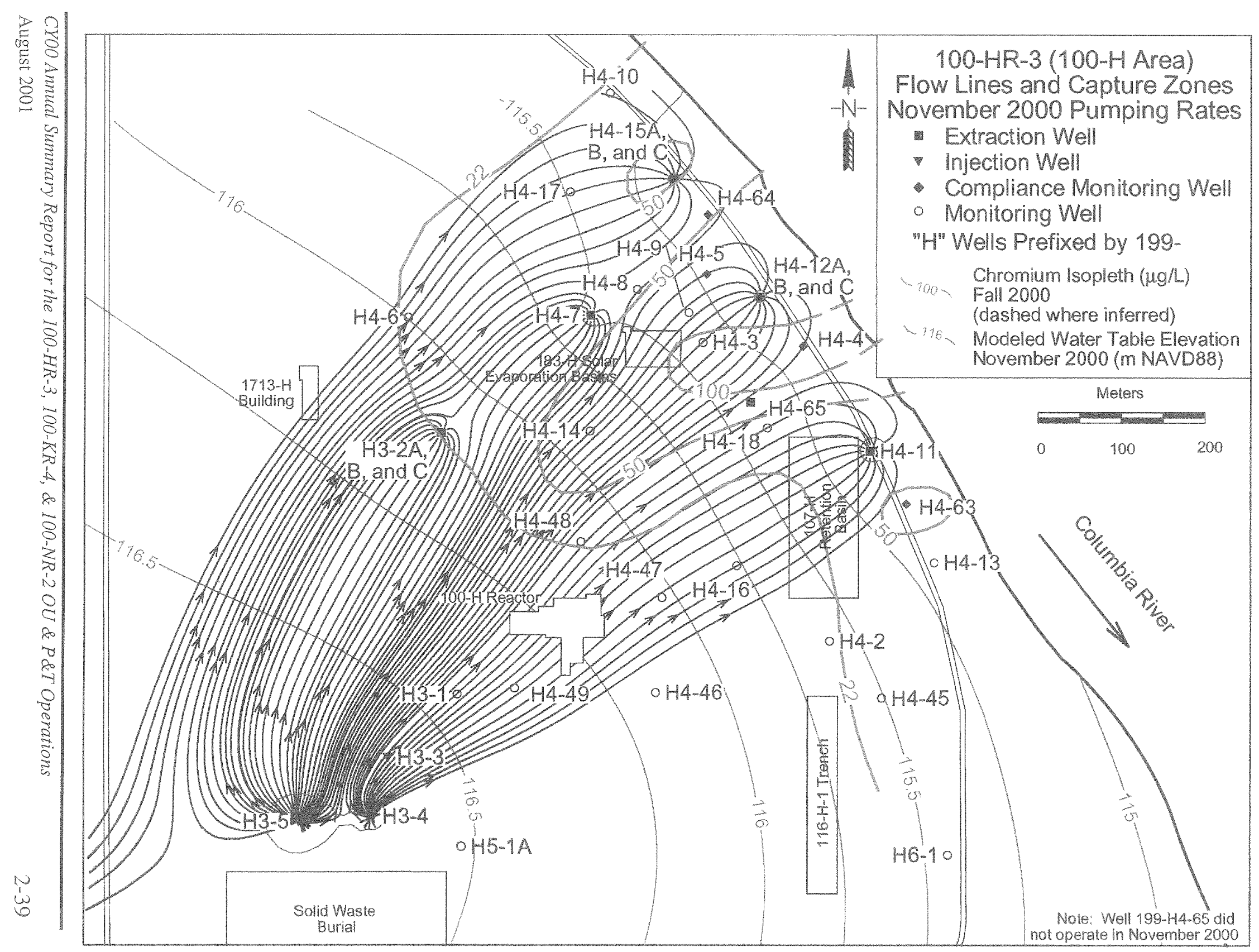

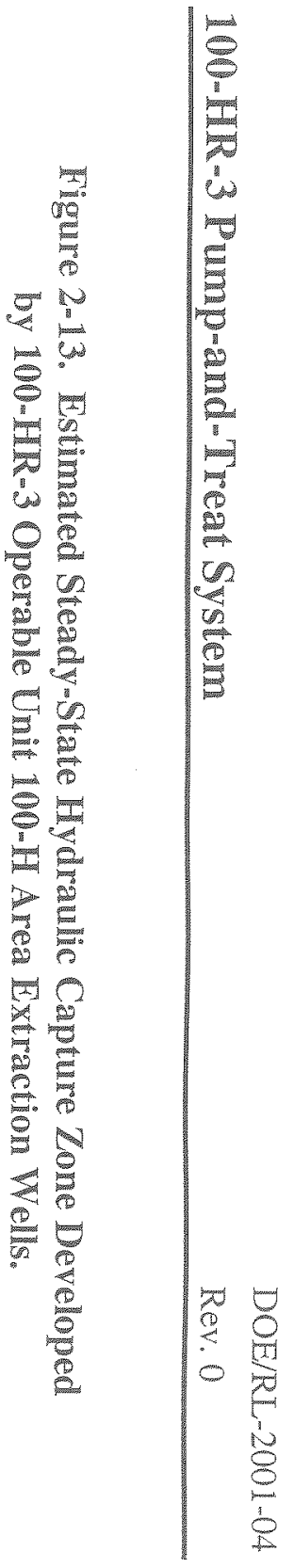




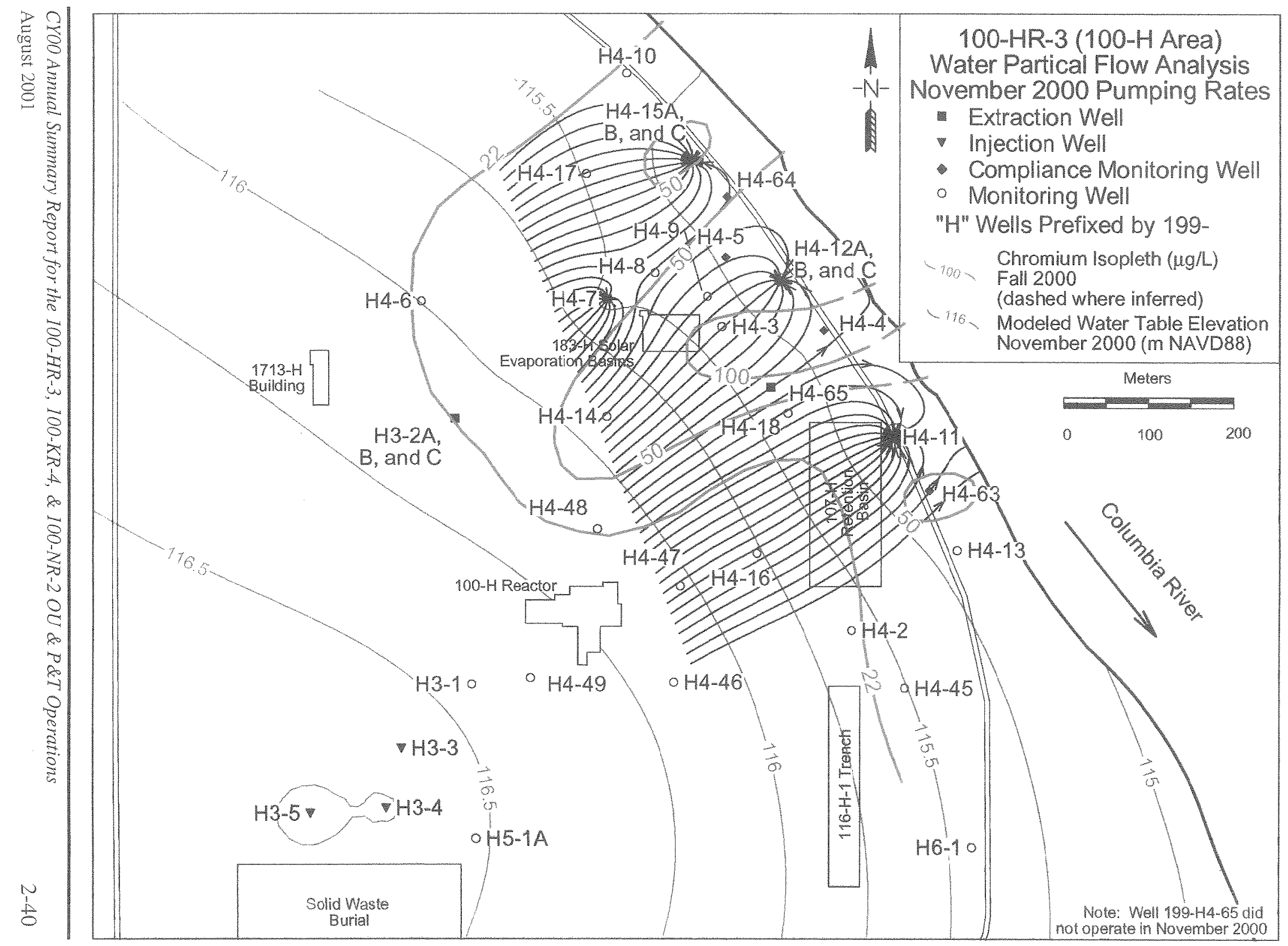

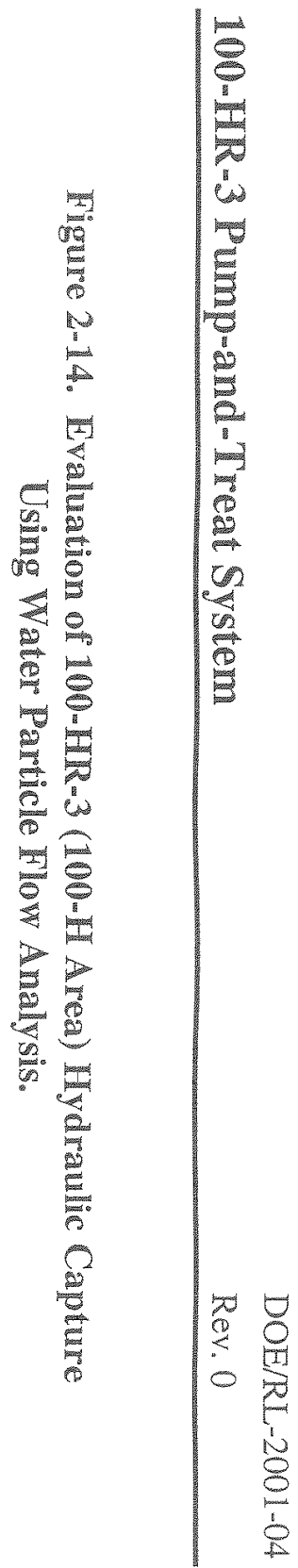



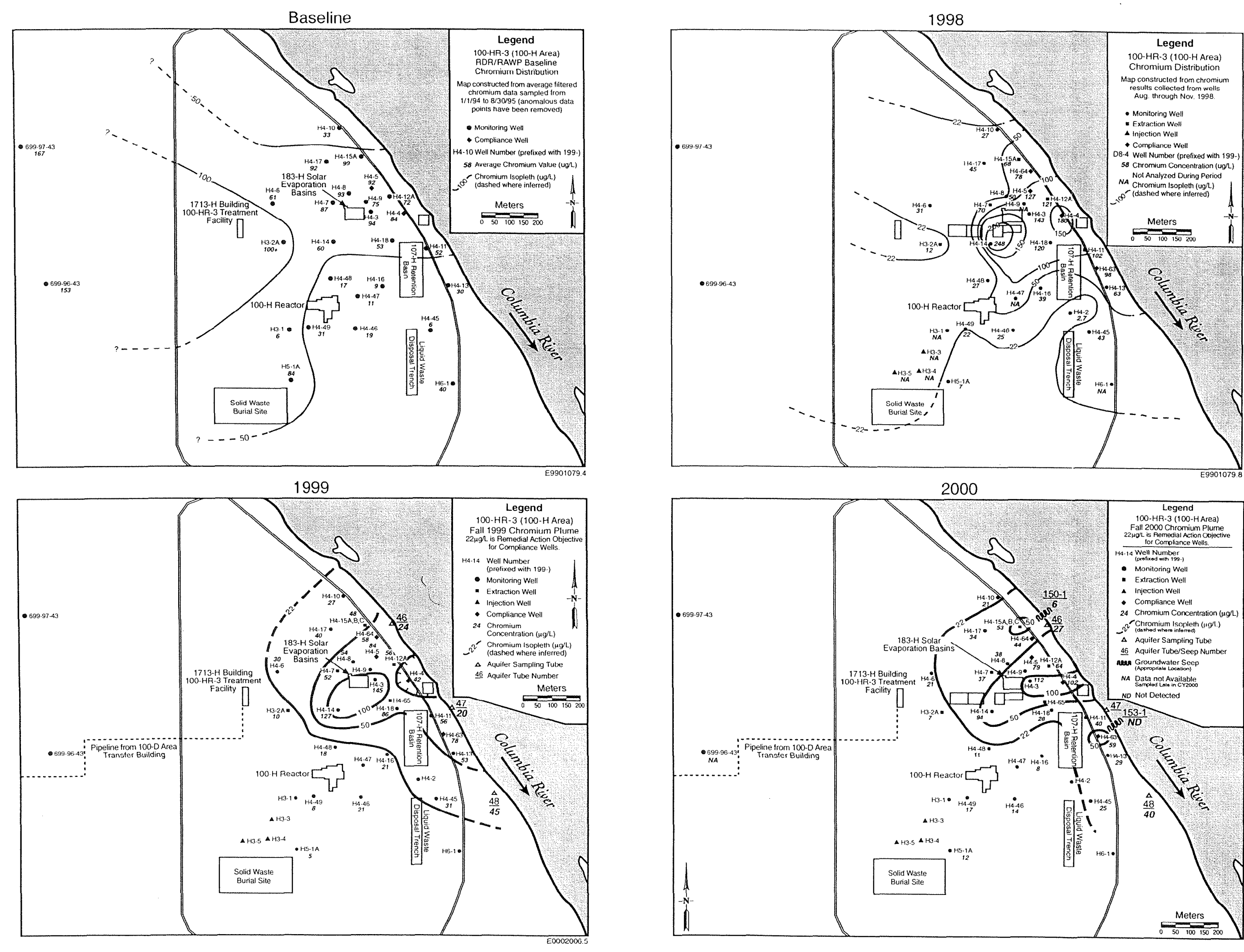

E0101121.9 
Figure 2-16. 100-HR-3 (100-H Area) Hexavalent Chromium Plume and Trend Plots

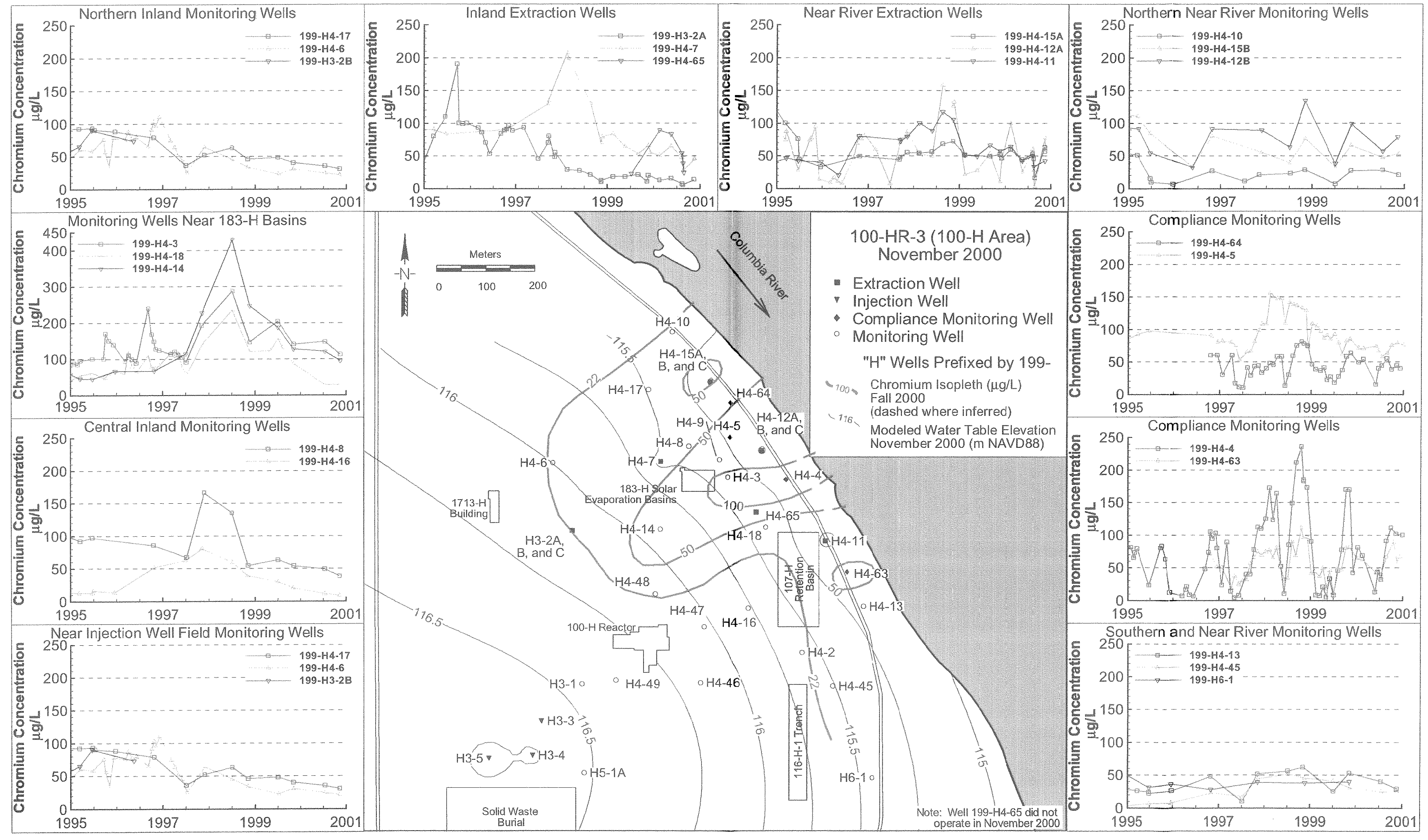


Table 2-1. 100-HR-3 Pump-and-Treat Summary of Operations for Calendar Year 2000.

\begin{tabular}{|l|c|c|}
\hline \multicolumn{1}{|c|}{ Activity } & CY 1999 & CY 2000 \\
\hline System availability $(\%)$ & 91.9 & 97.3 \\
\hline 100-D Area volume treated $(\mathrm{L})$ & $123,794,873$ & $135,722,674$ \\
\hline 100-H Area volume treated $(\mathrm{L})$ & $127,641,402$ & $169,440,167$ \\
\hline Total volume treated $(\mathrm{L})$ & $251,436,274$ & $305,162,841$ \\
\hline 100-D Area contaminant mass removed $(\mathrm{g})$ & 15,104 & 25,295 \\
\hline 100-H Area contaminant mass removed $(\mathrm{g})$ & 5,525 & 4,658 \\
\hline Total contaminant mass removed $(\mathrm{g})$ & 29,628 & 29,953 \\
\hline Removal efficiency $(\%$ by mass $)$ & 98.5 & 93.4 \\
\hline Waste generation $\left(\mathrm{m}^{3}\right)^{\mathrm{a}}$ & 41.4 & 62.1 \\
\hline Low-level radioactive waste generation $\left(\mathrm{m}^{3}\right)$ & 25.3 & 27.6 \\
\hline Regenerated resin installed $\left(\mathrm{m}^{3}\right)$ & 13.8 & 13.8 \\
\hline New resin installed $\left(\mathrm{m}^{3}\right)$ & 16.1 & 48.3 \\
\hline Number of resin changeouts & 18 & 27 \\
\hline
\end{tabular}

${ }^{2}$ Each ion-exchange vessel contains $2.3 \mathrm{~m}^{3}$ of ion-exchange resin.

$\mathrm{N} / \mathrm{A}=$ Not available because the $100-\mathrm{D}$ and $100-\mathrm{H}$ influent were combined prior to August 5, 1998.

Table 2-2. 100-HR-3 Extraction Well Chromium Concentrations. ${ }^{a}$

\begin{tabular}{|c|c|c|c|c|c|c|c|}
\hline Location & $\begin{array}{c}1997 \\
(\text { Feb-Dec) } \\
\text { Average } \mathrm{Cr}^{+6} \\
(\mu \mathrm{g} / \mathrm{L})\end{array}$ & \multicolumn{2}{|c|}{$\begin{array}{c}1998 \\
(\text { Feb-Dec) } \\
\text { Average Cr }{ }^{+6} \\
(\mu \mathrm{g} / \mathrm{L}) \\
\end{array}$} & $\begin{array}{c}\text { CY } 1999 \\
\text { Average Cr } \\
(\mu \mathrm{g} / \mathrm{L})\end{array}$ & $\begin{array}{c}\text { CY 2000 } \\
\text { Average Cr }{ }^{+6} \\
(\mu \mathrm{g} / \mathbf{L})\end{array}$ & 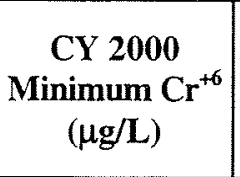 & $\begin{array}{c}\text { CY } 2000 \\
\text { Maximum } \mathrm{Cr}^{+6} \\
(\mu \mathrm{g} / \mathrm{L})\end{array}$ \\
\hline 199-D8-53 & 89 & \multicolumn{2}{|c|}{185} & 107 & 136 & 44 & 393 \\
\hline 199-D8-54A & 113 & \multicolumn{2}{|c|}{278} & 135 & 240 & 52 & 593 \\
\hline $199-\mathrm{H} 3-2 \mathrm{~A}$ & 59 & \multicolumn{2}{|c|}{20} & 17 & 8 & $3(U)$ & 21 \\
\hline 199-H4-7 & 118 & \multicolumn{2}{|c|}{116} & 59 & 45 & 27 & 81 \\
\hline 199-H4-11 & 61 & \multicolumn{2}{|c|}{90} & 51 & 38 & 20 & 76 \\
\hline $199-\mathrm{H} 4-12 \mathrm{~A}$ & 54 & \multicolumn{2}{|c|}{104} & 44 & 51 & $4(U)$ & 99 \\
\hline 199-H4-15A & 43 & \multicolumn{2}{|c|}{61} & 46 & 47 & 12 & 120 \\
\hline $199-\mathrm{H} 4-65$ & N/A & \multicolumn{2}{|c|}{ N/A } & N/A & 60 & 34 & 99 \\
\hline 100-D Area influent ${ }^{\mathrm{b}}$ & \multirow{2}{*}{88} & \multirow{2}{*}{146} & 273 & 121 & 192 & 49 & 313 \\
\hline $100-\mathrm{H}$ Area influent ${ }^{b}$ & & & 72 & 45 & 34 & 12 & 49 \\
\hline Effluent tank & 88 & 146 & 345 & 1.3 & 7 & $0(U)$ & 46 \\
\hline
\end{tabular}

${ }^{2}$ Data presented herein are stored in the project-specific database. The chromium data are also stored in the Hanford Environmental Information System database. These data are collected in support of operations.

${ }^{b}$ Prior to the system modification on August 5, 1998, the influent for the 100-D and 100-H Areas were combined.

N/A = not available; well 199-H4-65 came on-line in CY 2000.

Bolded values are above the RAO for hexavalent chromium $(22 \mu \mathrm{g} / \mathrm{L})$. 
Table 2-3. 100-HR-3 Technician's Duplicate Chromium Results.

\begin{tabular}{|c|c|c|c|c|c|c|c|}
\hline Well Name & $\begin{array}{c}\text { Sample } \\
\text { Number }\end{array}$ & $\begin{array}{c}\text { Sample } \\
\text { Date }\end{array}$ & $\begin{array}{c}\text { Chromium } \\
\text { Value } \\
\text { Reported } \\
\text { (mg/L) }\end{array}$ & $\begin{array}{c}\text { Sample } \\
\text { Number }\end{array}$ & $\begin{array}{c}\text { Sample } \\
\text { Date }\end{array}$ & $\begin{array}{c}\text { Chromium } \\
\text { Value } \\
\text { Reported } \\
\text { (mg/L) }\end{array}$ & RPD \\
\hline 199-H3-2A & B0XKF6 & 14 -Feb-00 & 0.012 & B0XKF7 & 14 -Feb-00 & 0.013 & $8 \%$ \\
\hline 199-H4-11 & B0YWP4 & 7-Aug-00 & 0.049 & B0YWP8 & 7-Aug-00 & 0.05 & $2 \%$ \\
\hline H-Effluent & B10RC2 & 13 -Nov-00 & 0.011 & B10RC3 & 13-Nov-00 & 0.011 & $0 \%$ \\
\hline 199-H3-2A & B10RB7 & 13 -Nov-00 & 0.014 & B10RB9 & 13 -Nov-00 & 0.013 & $-7 \%$ \\
\hline
\end{tabular}

Table 2-4. 100-HR-3 Quarterly Chromium Sampling and Operations Data Comparison. (2 Pages)

\begin{tabular}{|c|c|c|c|c|c|c|c|}
\hline Well Name & $\begin{array}{l}\text { Sample } \\
\text { Number }\end{array}$ & $\begin{array}{l}\text { Sample } \\
\text { Date }\end{array}$ & \begin{tabular}{|c|} 
Chromium \\
Value \\
Reported \\
(mg/L) \\
\end{tabular} & $\begin{array}{l}\text { Sample } \\
\text { Number }\end{array}$ & $\begin{array}{c}\text { Sample } \\
\text { Date }\end{array}$ & $\begin{array}{c}\text { Chromium } \\
\text { Value } \\
\text { Reported } \\
\text { (mg/L) } \\
\end{array}$ & RPD \\
\hline \multicolumn{4}{|c|}{ Quarterly and Annual Sample Results } & \multicolumn{4}{|c|}{ Operations Sample Results } \\
\hline $199-\mathrm{H} 3-2 \mathrm{~A}$ & B0XKF6 & $14-F e b-00$ & 0.012 & B0XCT9 & 9-Feb-00 & 0.008 & $40 \%$ \\
\hline $199-\mathrm{H} 3-2 \mathrm{~A}$ & B0Y433 & 15-May-00 & 0.015 & B0Y3H5 & 10-May-00 & 0.012 & $22 \%$ \\
\hline 199-H4-12A & B0Y438 & 15-May-00 & 0.025 & $\mathrm{~B} 0 \mathrm{Y} 3 \mathrm{H} 7$ & 10-May-00 & 0.016 & $44 \%$ \\
\hline 199-H4-15A & B0Y439 & 15-May-00 & 0.044 & B0Y3H8 & 10-May-00 & 0.023 & $63 \%$ \\
\hline 199-H4-11 & $\mathrm{B} 0 \mathrm{Y} 437$ & 15-May-00 & 0.042 & B0Y3H6 & 10-May-00 & 0.032 & $27 \%$ \\
\hline $199-\mathrm{H} 4-11$ & B10RB3 & $13-$ Nov-00 & 0.042 & $\mathrm{~B} 10 \mathrm{KLO}$ & 13-Nov-00 & 0.038 & $10 \%$ \\
\hline 199-H4-11 & B0YWP4 & 7-Aug-00 & 0.049 & BOYPVO & 10 -Aug-00 & 0.032 & $42 \%$ \\
\hline 199-H4-7 & B10RB6 & $13-$ Nov-00 & 0.044 & B10KL3 & 13-Nov-00 & 0.039 & $12 \%$ \\
\hline 199-H4-12A & B0YWP5 & 7-Aug-00 & 0.06 & B0YPV1 & 10-Aug-00 & 0.028 & $73 \%$ \\
\hline 199-H4-7 & B0XKF9 & 14-Feb-00 & 0.05 & B0XCV3 & 9-Feb-00 & 0.041 & $20 \%$ \\
\hline 199-H4-7 & B0YWP3 & 7-Aug-00 & 0.047 & B0YPV3 & 10-Aug-00 & 0.044 & $7 \%$ \\
\hline 199-H4-65 & B0YWP7 & 7 -Aug-00 & 0.054 & B0YPV4 & 10 -Aug-00 & 0.04 & $30 \%$ \\
\hline 199-H4-15A & B0YWP6 & 7-Aug-00 & 0.053 & B0YPV2 & 10-Aug-00 & 0.045 & $16 \%$ \\
\hline 199-H4-15A & B0XKH1 & 14-Feb-00 & 0.059 & B0XCV2 & 9-Feb-00 & 0.046 & $25 \%$ \\
\hline 199-H4-15A & B10RB5 & $13-$ Nov-00 & 0.063 & $\mathrm{~B} 10 \mathrm{KL} 2$ & 13-Nov-00 & 0.044 & $36 \%$ \\
\hline 199-D8-53 & BoY430 & 15-May-00 & 0.062 & $\mathrm{~B} 0 \mathrm{Y} 3 \mathrm{H} 3$ & 10-May-00 & 0.046 & $30 \%$ \\
\hline 199-H4-7 & B0Y435 & 15-May-00 & 0.063 & B0Y3H9 & 10-May-00 & 0.053 & $17 \%$ \\
\hline 199-H4-11 & B0XKH2 & 14-Feb-00 & 0.064 & BoXCV0 & 9-Feb-00 & 0.053 & $19 \%$ \\
\hline 199-D8-54A & B0Y431 & 15-May-00 & 0.071 & B0Y3H4 & 10-May-00 & 0.06 & $17 \%$ \\
\hline $199-\mathrm{H} 4-12 \mathrm{~A}$ & B10RB4 & $13-$ Nov-00 & 0.077 & B10KL1 & 13-Nov-00 & 0.069 & $11 \%$ \\
\hline 199-H4-65 & B0Y440 & 15-May-00 & 0.083 & B0Y3J0 & 10-May-00 & 0.072 & $14 \%$ \\
\hline 199-H4-12A & $\mathrm{B} 0 \mathrm{XKH} 0$ & 14-Feb-00 & 0.099 & B0XCV1 & 9-Feb-00 & 0.097 & $2 \%$ \\
\hline 199-D8-53 & B0YWP1 & 7-Aug-00 & 0.124 & B0YPT7 & 10 -Aug-00 & 0.105 & $17 \%$ \\
\hline 199-D8-53 & B0XKH6 & 14-Feb-00 & 0.125 & B0XCT7 & 9-Feb-00 & 0.116 & $7 \%$ \\
\hline 199-D8-54A & B0XKH7 & 14-Feb-00 & 0.208 & B0XCT8 & 9-Feb-00 & 0.191 & $9 \%$ \\
\hline
\end{tabular}


Table 2-4. 100-HR-3 Quarterly Chromium Sampling and Operations Data Comparison. (2 Pages)

\begin{tabular}{|c|c|c|c|c|c|c|c|}
\hline Well Name & $\begin{array}{c}\text { Sample } \\
\text { Number }\end{array}$ & $\begin{array}{c}\text { Sample } \\
\text { Date }\end{array}$ & $\begin{array}{c}\text { Chromium } \\
\text { Value } \\
\text { Reported } \\
\text { (mg/L) }\end{array}$ & $\begin{array}{c}\text { Sample } \\
\text { Number }\end{array}$ & $\begin{array}{c}\text { Sample } \\
\text { Date }\end{array}$ & $\begin{array}{c}\text { Chromium } \\
\text { Value } \\
\text { Reported } \\
\text { (mg/L) }\end{array}$ & RPD \\
\hline \multicolumn{6}{|c|}{ Quarterly and Annual Sample Results } & \multicolumn{5}{|c|}{ Operations Sample Results } \\
\hline 199-D8-53 & B10RB1 & 13 -Nov-00 & 0.214 & B10KK7 & 13 -Nov-00 & 0.202 & $6 \%$ \\
\hline 199-D8-54A & B0YWP2 & 7-Aug-00 & 0.285 & B0YPT8 & 10 -Aug-00 & 0.267 & $7 \%$ \\
\hline 199-D8-54A & B10RB2 & 13 -Nov-00 & 0.338 & B10KK8 & 13 -Nov-00 & 0.32 & $5 \%$ \\
\hline
\end{tabular}

Table 2-5. 100-HR-3 Field and Analytical Laboratory Splits.

\begin{tabular}{|c|c|c|c|c|c|c|c|}
\hline \multicolumn{4}{|c|}{ Field Data (using Hach Kit) } & \multicolumn{4}{|c|}{$\begin{array}{l}\text { Analytical Laboratory Data } \\
\text { (using EPA Method 7196 CR6) }\end{array}$} \\
\hline Well Name & $\begin{array}{l}\text { Sample } \\
\text { Number }\end{array}$ & Sample Date & $\begin{array}{c}\text { Chromium } \\
\text { Value } \\
\text { Reported } \\
(\mathrm{mg} / \mathrm{L})\end{array}$ & $\begin{array}{l}\text { Sample } \\
\text { Number }\end{array}$ & Sample Date & $\begin{array}{l}\text { Chromium } \\
\text { Value } \\
\text { Reported } \\
\text { (mg/L) }\end{array}$ & RPD \\
\hline 199-H3-2A & B0XKF6 & 14-Feb-00 & 0.012 & B0XKH4 & 14-Feb-00 & 0.011 & $-9 \%$ \\
\hline $199-\mathrm{H} 3-2 \Lambda$ & BOY 433 & 15-May-00 & 0.015 & B0Y428 & 15-May-00 & 0.014 & $-7 \%$ \\
\hline 199-H3-2A & B10RB9 & 13-Nov-00 & 0.013 & B10R98 & 13-Nov-00 & 0.009 & $-36 \%$ \\
\hline 199-H4-11 & B0YWP4 & 7-Aug-00 & 0.049 & B0YWV6 & 7-Aug-00 & 0.048 & $-2 \%$ \\
\hline H-Effluent & B0Y434 & 15-May-00 & 0.028 & B0Y429 & 15-May-00 & 0.03 & $7 \%$ \\
\hline H-Effluent & $\mathrm{B} 10 \mathrm{RC} 2$ & 13-Nov-00 & 0.011 & B10RB0 & 13-Nov-00 & 0.006 & $-59 \%$ \\
\hline H-Influent & B0XKF4 & 14-Feb-00 & 0.052 & B0XKH3 & 14-Feb-00 & 0.051 & $-2 \%$ \\
\hline H-Influent & B0Y432 & 15-May-00 & 0.043 & B0Y427 & 15 -May-00 & 0.042 & $-2 \%$ \\
\hline H-Influent & B0YWP9 & 7-Aug-00 & 0.039 & BOYWV7 & 7 -Aug-00 & 0.035 & $-11 \%$ \\
\hline H-Influent & B10RC1 & $13-$ Nov-00 & 0.045 & B10R99 & $13-$ Nov-00 & 0.04 & $-12 \%$ \\
\hline
\end{tabular}

Table 2-6. 100-HR-3 Co-Contaminant Concentrations in Extraction Wells. (3 Pages)

\begin{tabular}{|c|c|c|c|c|c|}
\hline Well & $\begin{array}{l}\text { CY } 1997 \\
\text { Average }\end{array}$ & $\begin{array}{l}\text { CY } 1998 \\
\text { Average }\end{array}$ & $\begin{array}{l}\text { CY } 1999 \\
\text { Average }\end{array}$ & $\begin{array}{l}\text { CY } 2000 \\
\text { Average }\end{array}$ & $\begin{array}{l}\text { Long-Term } \\
\text { Trend }^{\mathrm{a}}\end{array}$ \\
\hline \multicolumn{6}{|c|}{ Nitrate $(\mathrm{mg} / \mathrm{L})$} \\
\hline 199-D8-53 & $\ldots$ & -- & -- & $\ldots$ & $c$ \\
\hline 199-D8-54A & - & --- & -- & $\ldots$ & $c$ \\
\hline $199-\mathrm{H} 3-2 \mathrm{~A}$ & -- & 38 & 36 & 35 & Stable $^{b}$ \\
\hline 199-H4-7 & $\ldots$ & 36 & 44 & 53 & Increasing \\
\hline 199-H4-11 & --- & 44 & 31 & 22 & Decreasing \\
\hline $199-\mathrm{H} 4-12 \mathrm{~A}$ & -- & 84 & 5 & 14 & Decreasing \\
\hline 199-H4-15A & -- & 26 & 29 & 20 & Stable $^{b}$ \\
\hline 199-H4-65 & --- & -- & - & 82 & $\bar{c}$ \\
\hline
\end{tabular}


Table 2-6. 100-HR-3 Co-Contaminant Concentrations in Extraction Wells. (3 Pages)

\begin{tabular}{|c|c|c|c|c|c|}
\hline Well & $\begin{array}{l}\text { CY } 1997 \\
\text { Average }\end{array}$ & $\begin{array}{l}\text { CY } 1998 \\
\text { Average }\end{array}$ & $\begin{array}{l}\text { CY } 1999 \\
\text { Average }\end{array}$ & $\begin{array}{l}\text { CY } 2000 \\
\text { Average }\end{array}$ & $\begin{array}{l}\text { Long-Term } \\
\text { Trend }^{\mathrm{a}}\end{array}$ \\
\hline \multicolumn{6}{|c|}{ Total beta radiostrontium $(\mathrm{pCi} / \mathrm{L})$} \\
\hline 199-D8-53 & $3.1(+/-1.2)$ & $4.9(+/-1.2)$ & --- & $2.3(+/-0.5)$ & Decreasing \\
\hline 199-D8-54A & $3.0(+/-1.2)$ & $5.6(+/-1.3)$ & --- & $2.6(+/-0.4)$ & Stable $^{b}$ \\
\hline $199-\mathrm{H} 3-2 \mathrm{~A}$ & $0.1(+/-0.2) \mathrm{U}$ & $-0.1(+/-0.3) \mathrm{U}$ & $-0.1(+/-0.3) \mathrm{U}$ & $-0.2(+/-0.3) \mathrm{U}$ & Undetected \\
\hline $199-\mathrm{H} 4-7$ & --- & $0.2(+/-0.6) \mathrm{U}$ & $-0.2(+/-0.4) \mathrm{U}$ & $-0.1(+/-0.3) \mathrm{U}$ & Undetected \\
\hline 199-H4-11 & $24.3(+/-8.7)$ & $28.4(+/-6.4)$ & $25.5(+/-2.9)$ & $19(+/-2.1)$ & Stable $^{b}$ \\
\hline 199-H4-12A & $0.6(+/-0.3)$ & $12.7(+/-4.4)$ & $0(+1-0.3) \mathrm{U}$ & $0.05(+/-0.3) \mathrm{U}$ & Stable $^{b}$ \\
\hline $199-\mathrm{H} 4-15 \mathrm{~A}$ & $0.03(+/-0.2) \mathrm{U}$ & $-0.06(+1-0.4) \mathrm{U}$ & $-0.1(+/-0.3) \mathrm{U}$ & $-0.1(+/-0.3) \mathrm{U}$ & Undetected \\
\hline 199-H4-65 & -- & -- & -- & $3.6(+/-0.5)$ & c \\
\hline \multicolumn{6}{|c|}{ Technetium-99 (pCi/L) } \\
\hline $199-D 8-53$ & --- & $\cdots$ & $\cdots$ & -- & c \\
\hline $199-\mathrm{D} 8-54 \mathrm{~A}$ & -- & $-\cdots$ & $-\cdots$ & -- & $\mathrm{c}$ \\
\hline 199-H3-2A & $1(+/-6) \mathrm{U}$ & $0.05(+/-14) \mathrm{U}$ & $30(+/-6) \mathrm{B}$ & $40(+/-12) \mathrm{B}$ & Increasing \\
\hline $199-\mathrm{H} 4-7$ & $2,080(+/-229)$ & $22(+/-16)$ & $18(+/-9) \mathrm{B}$ & $36(+/-15) \mathrm{B}$ & Decreasing \\
\hline 199-H4-11 & $54(+/-16)$ & $42(+/-16)$ & $43(+/-8) \mathrm{B}$ & $60(+/-10) B$ & Stable $^{b}$ \\
\hline 199-H4-12A & $255(+/-35)$ & $242(+/-36)$ & $82(+/-14)$ & $79(+/-14)$ & Decreasing \\
\hline 199-H4-15A & $5(+/-11) U$ & $0.3(+/-15) \mathrm{U}$ & $10(+/-9) \mathrm{B}$ & $20(+/-10) \mathrm{B}$ & Increasing \\
\hline 199-H4-65 & -- & $-\cdots$ & -- & $166(+/-22) \mathrm{B}$ & $\mathrm{c}$ \\
\hline \multicolumn{6}{|c|}{ Tritium (pCi/L) } \\
\hline 199-D8-53 & $3,000(+/-410)$ & $6,455(+t-709)$ & --- & $1,320(+/-210)$ & Decreasing \\
\hline 199-D8-54A & $2,483(+/-374)$ & $8,600(+/-940)$ & -- & $1,420(+/-210)$ & Decreasing \\
\hline 199-H3-2A & $3,547(+/-444)$ & $3,453(+/-429)$ & $4,115(+/-460)$ & $3,435(+/-395)$ & Stable $^{b}$ \\
\hline 199-H4-7 & $3,040(+/-418)$ & $3,205(+/-407)$ & $3,400(+/-390)$ & $3,610(+/-420)$ & Increasing \\
\hline 199-H4-11 & $1,275(+/-286)$ & $3,105(+/-400)$ & $1,780(+/-240)$ & $1,420(+/-210)$ & Stable $^{b}$ \\
\hline 199-H4-12A & $1,175(+/-276)$ & $1,605(+/-275)$ & $447(+/-140)$ & $857(+/-160)$ & Decreasing \\
\hline 199-H4-15A & $1,157(+/-278)$ & $1,855(+/-292)$ & $2,460(+/-310)$ & $1,700(+/-240)$ & Increasing \\
\hline 199-H4-65 & $\ldots$ & --- & -- & $3,780(+/-440)$ & c \\
\hline \multicolumn{6}{|c|}{ Uranium $(\mu \mathrm{g} / \mathrm{L})$} \\
\hline 199-D8-53 & -- & --- & $\cdots$ & -- & $\mathrm{c}$ \\
\hline 199-D8-54A & $\cdots$ & $\cdots$ & -- & $-\cdots$ & c \\
\hline 199-H3-2A & $4.1(+/-0.6)$ & $3.3(+/-0.5)$ & $2.0(+/-0.3)$ & -- & c \\
\hline 199-H4-7 & $106(+/-23.4)$ & $5.1(+/-0.7)$ & $3.9(+1-0.6)$ & $3.2(+/-0.8)$ & Decreasing \\
\hline 199-H4-11 & $8.5(+/-1.2)$ & $9.6(+/-1.8)$ & $6.1(+/-0.9)$ & $6.0(+/-0.9)$ & Decreasing \\
\hline 199-H4-12A & $20.4(+/-4.1)$ & $20.5(+/-4.1)$ & $5.4(+/-1.2)$ & $15.8(+/-3.8)$ & Decreasing \\
\hline
\end{tabular}


Table 2-6. 100-HR-3 Co-Contaminant Concentrations in Extraction Wells. (3 Pages)

\begin{tabular}{|c|c|c|c|c|c|}
\hline Well & $\begin{array}{c}\text { CY 1997 } \\
\text { Average }\end{array}$ & $\begin{array}{c}\text { CY 1998 } \\
\text { Average }\end{array}$ & $\begin{array}{c}\text { CY 1999 } \\
\text { Average }\end{array}$ & $\begin{array}{c}\text { CY 2000 } \\
\text { Average }\end{array}$ & $\begin{array}{c}\text { Long-Term } \\
\text { Trend }^{2}\end{array}$ \\
\hline $199-\mathrm{H} 4-15 \mathrm{~A}$ & $1.7(+/-0.3)$ & $2.5(+/-0.4)$ & $2.2(+/-0.3)$ & $2.0(+/-0.5)$ & Stable $^{b}$ \\
\hline $199-\mathrm{H} 4-65$ & --- & --- & --- & $\mathrm{c}$ \\
\hline
\end{tabular}

${ }^{a}$ Long-term trend is based on a comparison of CY 2000 data to CY 1997 data (or next earliest data available).

${ }^{b}$ Trends are considered stable when the change between CY 2000 and CY 1997 is less than $+1-20 \%$.

Not trended; insufficient data available.

$\mathrm{U}=$ undetected

$\mathrm{J}=$ estimated

$\mathrm{B}=$ The associated QC sample blank had a result greater than or equal to the minimum detectable activity, and after corrections, the result is greater than or equal to the minimum detectable activity for this sample.

Bolded values represent concentrations/activities above the $\mathrm{MCL}$ for the particular constituent. 


\section{Table 2-7. 100-HR-3 (100-D Area) Water-Level Data and Results of the Drawdown/Buildup Analysis Used to Develop and Calibrate Numerical Groundwater Flow Models.}

\begin{tabular}{|c|c|c|c|c|c|c|c|c|}
\hline \multirow[b]{2}{*}{ Well } & \multicolumn{2}{|c|}{$\begin{array}{l}\text { Model Analysis } \\
\text { November } 2000\end{array}$} & \multirow{2}{*}{$\begin{array}{c}\text { Measured } \\
\text { Water-Level } \\
\text { Elevation } \\
\text { Nov 2000 } \\
\text { (m NAVD88) }\end{array}$} & \multirow{2}{*}{$\begin{array}{c}\text { Modeled } \\
\text { Water-Level } \\
\text { Elevation } \\
\text { Nov 2000 } \\
\text { (m NAVD88) }\end{array}$} & \multicolumn{4}{|c|}{$\begin{array}{l}\text { Drawdown/Buildup Analysis } \\
\text { January - March } 2000\end{array}$} \\
\hline & $\begin{array}{c}\text { Extraction } \\
\text { Rate } \\
\text { (L/min) }\end{array}$ & $\begin{array}{c}\text { Injection } \\
\text { Rate } \\
(\mathrm{L} / \mathrm{min})\end{array}$ & & & $\begin{array}{c}\text { Extraction } \\
\text { Rate } \\
(\text { L/min })\end{array}$ & $\begin{array}{l}\text { Injection } \\
\text { Rate } \\
(\mathrm{L} / \mathrm{min})\end{array}$ & $\begin{array}{c}\text { Drawdown } \\
(\mathbf{m})\end{array}$ & Buildup (m) \\
\hline 199-D8-53 & 148 & $-\ldots$ & 116.89 & 116.9 & 115 & -- & 0.35 & -- \\
\hline $199-\mathrm{D} 8-54 \mathrm{~A}$ & 157 & -- & 116.94 & 116.93 & 149 & - & 0.28 & --- \\
\hline 199-D8-68 & $\cdots$ & -- & 117.25 & 117.2 & $\ldots$ & $\ldots$ & 0.03 & -- \\
\hline 199-D8-69 & $\ldots-$ & $\ldots$ & 117.31 & 117.19 & $\overline{---}$ & --- & 0.01 & $\ldots$ \\
\hline 199-D8-70 & --- & -- & 117.28 & 117.31 & --- & -- & 0.02 & -- \\
\hline 199-D8-71 & - & -- & 117.27 & 117.2 & - & -- & 0.04 & $-\cdots$ \\
\hline 100-D River & $\ldots$ & -- & 117.38 & $\ldots$ & $\cdots$ & -- & -- & -- \\
\hline
\end{tabular}

Table 2-8. CY 2000 Groundwater Monitoring Network and Sampling Frequencies at 100-D Area.

\begin{tabular}{|c|c|c|c|}
\hline $\begin{array}{c}\text { Type of Monitoring } \\
\text { Location }\end{array}$ & $\begin{array}{l}\text { Number of } \\
\text { Locations }\end{array}$ & $\begin{array}{l}\text { Monitoring } \\
\text { Frequency }\end{array}$ & Comments \\
\hline Compliance wells & 3 & Monthly & \\
\hline Extraction wells & 2 & Weekly & $\begin{array}{l}\text { Weekly samples collected and analyzed by } \\
\text { the on-site process operator. QC samples } \\
\text { collected quarterly for onsite and laboratory } \\
\text { analysis. }\end{array}$ \\
\hline OU Monitoring wells & 16 & $\begin{array}{l}\text { Quarterly, } \\
\text { annual, and } \\
\text { bi-annual }\end{array}$ & See sample matrix contained in Appendix E \\
\hline Sample tubes & 6 & Annually & Samples collected in the fall. \\
\hline Riverbank seepage & 2 & Annually & Samples collected in the fall. \\
\hline
\end{tabular}

Note: Number of monitoring locations does not include ISRM monitoring locations. 
Table 2-9. Construction Details and Use of Each 100-D Area Well. (2 Pages)

\begin{tabular}{|c|c|c|c|c|c|}
\hline Well & $\begin{array}{c}\text { Date } \\
\text { Completed } \\
\end{array}$ & $\begin{array}{c}\begin{array}{c}\text { Screened Interval } \\
\text { (ft/type) }\end{array} \\
\end{array}$ & $\begin{array}{l}\text { Depth to } \\
\text { Bottom }^{\mathrm{a}}\end{array}$ & $\begin{array}{c}\text { Water Level }^{\mathrm{b}} \\
\text { (ft) }\end{array}$ & Well Use \\
\hline 199-D2-6 & Feb 92 & 77-98/4-in. SS & 98 & 84.86 & $M$ \\
\hline 199-D3-2 & Sept 97 & 82-102/6-in. SS & 105 & 84.38 & M \\
\hline 199-D4-1 & Oct 96 & 75-95/6-in. SS & 98 & $83.69(2 / 98)$ & ISRM barrier \\
\hline 199-D4-2 & May 97 & 84-88, 94-98/4-in PVC & 99 & $79.81(5 / 97)$ & ISRM barrier \\
\hline 199-D4-3 & May 97 & 84-88, 94-98/4-in PVC & 99 & $79.15(5 / 97)$ & ISRM barrier \\
\hline 199-D4-4 & May 97 & 78-98/4-in PVC & 98 & $77.84(5 / 97)$ & ISRM barrier \\
\hline 199-D4-5 & May 97 & 78-98/4-in PVC & 98 & $76.44(5 / 97)$ & ISRM barrier \\
\hline 199-D4-6 & June 97 & 76-96/4-in PVC & 96 & $74.3(6 / 97)$ & ISRM barrier \\
\hline 199-D4-7 & June 97 & 81-95/6-in PVC & 96 & $74.25(6 / 97)$ & ISRM barrier \\
\hline 199-D4-8 & June 97 & 76--95/4-in PVC & 96 & $75.25(6 / 97)$ & ISRM barrier \\
\hline 199-D4-9 & June 97 & 81-90, 92-96/6-in PVC & 97 & $75.5(6 / 97)$ & ISRM barrier \\
\hline 199-D4-10 & July 97 & 82-96/6-in PVC & 97 & $75.9(7 / 97)$ & ISRM barrier \\
\hline 199-D4-11 & June 97 & 81-95/6-in PVC & 96 & $74.9(6 / 97)$ & ISRM barrier \\
\hline 199-D4-13 & Sept 97 & 72-92/6-in. SS & 95 & 85.07 & $\mathrm{M}$ \\
\hline 199-D4-14 & Sept 97 & $76-96 / 6$-in. SS & 99 & 86.69 & $M$ \\
\hline 199-D4-15 & Sept 97 & $77-97 / 6$-in. SS & 100 & 86.78 & $M$ \\
\hline 199-D4-16 & July 97 & 80-82, 87-89, 93-95/4-in PVC & 101 & $76.65(7 / 97)$ & ISRM barrier \\
\hline 199-D4-17 & Sept 97 & 81-83, 87-89, 94-96/4-in PVC & 102 & & ISRM barrier \\
\hline 199-D4-18 & Sept 97 & 80-82, 86-88, 93-95/4-in PVC & 100 & $86.02(9 / 97)$ & ISRM barrier \\
\hline 199-D4-19 & May 99 & $77-107 / 6$-in SS & 110 & 84.82 & $\mathrm{M}$ \\
\hline 199-D4-20 & May 99 & 81-101/6-in SS & 104 & 85.79 & $\mathrm{M}$ \\
\hline 199-D4-21 & Mar 99 & 82-97/6-in SS & 97 & $80.59(3 / 99)$ & ISRM barrier \\
\hline 199-D4-22 & May 99 & 79-99/4-in PVC & 99 & $82.3(5 / 99)$ & $\mathrm{M}$ \\
\hline 199-D4-23 & June 99 & 64-84 / 4-in PVC & 85 & $70.45(6 / 99)$ & $\mathrm{M}$ \\
\hline 199-D4-38 & Mar 00 & 75-95/6-in. SS & 102.5 & 83.84 & ISRM \\
\hline 199-D5-13 & Nov 91 & 77-97/4-in. SS & 97 & 88.14 & $\mathrm{M}$ \\
\hline 199-D5-14 & Feb 92 & 77-98/4-in. SS & 98 & $84.34(11 / 98)$ & $\mathrm{M}$ \\
\hline 199-D5-15 & Feb 92 & $77-98 / 4$-in. SS & 98 & 86.96 & $\mathrm{M}$ \\
\hline 199-D5-16 & Jan 92 & 77-98/4-in. SS & 98 & $85.84(11 / 98)$ & $\mathrm{M}$ \\
\hline 199-D5-17 & Feb 92 & 75-96/4-in. SS & 96 & $80.88(11 / 98)$ & $\mathrm{M}$ \\
\hline 199-D5-18 & $\operatorname{Jan} 92$ & 68-93/4-in. SS & 93 & $78.97(11 / 98)$ & $\mathrm{M}$ \\
\hline 199-D5-19 & $\operatorname{Jan} 92$ & 75-95/4-in. SS & 95 & 79.40 & $\mathrm{M}$ \\
\hline 199-D5-20 & $\operatorname{Jan} 92$ & 76-97/4-in. SS & 97 & 85.35 & $\mathrm{M}$ \\
\hline 199-D5-36 & Mar 99 & $75-95 / 6$-in SS & 98 & 84.90 & $\mathrm{M}$ \\
\hline 199-D5-37 & Apr 99 & 78-93/6-in SS & 96 & 85.52 & $\mathrm{M}$ \\
\hline 199-D5-38 & Apr 99 & 82-102/6-in SS & 105 & 87.31 & $\mathrm{M}$ \\
\hline 199-D5-39 & Apr 99 & 80-100/6-in SS & 103 & 86.88 & $\mathrm{M}$ \\
\hline 199-D5-40 & Apr 99 & 83-103/6-in SS & 106 & 87.16 & $\mathrm{M}$ \\
\hline
\end{tabular}


Table 2-9. Construction Details and Use of Each 100-D Area Well. (2 Pages)

\begin{tabular}{|c|c|c|c|c|c|}
\hline Well & $\begin{array}{c}\text { Date } \\
\text { Completed }\end{array}$ & $\begin{array}{c}\text { Screened Interval } \\
\text { (ft/type) }\end{array}$ & $\begin{array}{l}\text { Depth to } \\
\text { Bottom }^{\mathrm{a}}\end{array}$ & $\begin{array}{c}\text { Water Level } \\
\text { (ft) }\end{array}$ & Well Use \\
\hline 199-D5-41 & Apr 99 & 81-101/6-in SS & 104 & 85.76 & $\mathrm{M}$ \\
\hline 199-D5-42 & Apr 99 & 83-103/6-in SS & 106 & 85.90 & M \\
\hline 199-D5-43 & Apr 99 & 79-104/6-in SS & 107 & 85.89 & M \\
\hline 199-D5-44 & Mar 99 & $77-92 / 6$-in SS & 96 & 83.82 & $M$ \\
\hline 188-D8-4 & Nov 91 & 74-94/3-in. SS & 95 & 85.90 & $\mathrm{M}$ \\
\hline 199-D8-5 & Oct 91 & 63-83/3-in. SS & 83 & $68.06(11 / 98)$ & $\mathrm{M}$ \\
\hline 199-D8-53 & Dec 91 & 45-65/4-in SS & 65 & 53.65 & $E$ \\
\hline 199-D8-54A & Nov 91 & $52-72 / 4$-in. SS & 72 & $58.85(2 / 97)$ & $E$ \\
\hline 199-D8-54B & $\operatorname{Jan} 92$ & 130-140/4-in. SS & 140 & 60.79 & $\mathrm{M}$ \\
\hline 199-D8-55 & Jan 92 & 49-69/4-in. SS & 69 & $56.73(11 / 97)$ & $\mathrm{M}$ \\
\hline 199-D8-6 & Dec 91 & 87-107/4-in. SS & 108 & 93.77 & $\mathrm{M}$ \\
\hline 199-D8-68 & July 96 & 48-73/6-in. SS & 76 & 61.18 & $\mathrm{C}$ \\
\hline 199-D8-69 & July 96 & 37-57/6-in. SS & 60 & 47.10 & $\mathrm{C}$ \\
\hline 199-D8-70 & July 96 & $41-71 / 6$-in. SS & 74 & 51.76 & $\mathrm{C}$ \\
\hline 199-D8-71 & July 96 & 46-76/6-in SS & 79 & 57.52 & $\mathrm{M}$ \\
\hline $699-96-49$ & $\begin{array}{l}\text { Oct } 62 \\
\text { June } 77\end{array}$ & $\begin{array}{l}28-60 / 8 \text {-in. PCS } \\
79-89 / 1.5 \text {-in. SS } \\
\end{array}$ & 89 & 37.15 & M \\
\hline 699-97-51A & ND & 12-39/8-in. PCS & 36 & 20.72 & $\mathrm{M}$ \\
\hline
\end{tabular}

${ }^{\mathrm{a}}$ All depths are in feet below ground surface.

${ }^{b}$ Water levels measured on November 13, 2000 or November 17, 2000, unless noted otherwise.

$\mathrm{E} \quad=$ extraction well

$\mathrm{C} \quad$ = compliance well

I = injection well

$\mathrm{M} \quad$ = monitoring well

$\mathrm{ND}=$ not documented

PCS = perforated carbon-steel well casing

$\mathrm{PVC}=$ polyvinyl chloride

$\mathrm{SS}=$ stainless-steel screen 
Table 2-10. Selected Chromium Data for 100-D Area Wells. ${ }^{a}$

\begin{tabular}{|c|c|c|c|c|c|c|c|}
\hline Well Name & Well ID & $\begin{array}{l}\text { CY } 1997 \\
\text { Average }\end{array}$ & $\begin{array}{l}\text { CY } 1998 \\
\text { Average }\end{array}$ & $\begin{array}{l}\text { CY } 1999 \\
\text { Average } \\
\end{array}$ & $\begin{array}{l}\text { CY } 2000 \\
\text { Average }\end{array}$ & $\begin{array}{c}\text { Short-Term } \\
\text { Trend }\end{array}$ & $\begin{array}{c}\text { Long-Term } \\
\text { Trend }\end{array}$ \\
\hline 199-D5-13 & $\mathrm{A} 4570$ & 364 & 320 & 386 & 426.3 & Stable & Increasing \\
\hline 199-D5-14 & A4571 & 458 & 692.8 & 839 & & c & Stable \\
\hline 199-D5-15 & $\Lambda 4572$ & 777 & 746.2 & 144 & 72 & Decreasing & Decreasing \\
\hline 199-D5-16 & A4573 & 648 & 422 & 313 & 251.5 & Decreasing & Decreasing \\
\hline 199-D5-17 & A4574 & 20.4 & -- & - & -- & $\mathrm{c}$ & Stable \\
\hline 199-D5-18 & A4575 & - & 33.2 & - & - & $c$ & $\mathrm{c}$ \\
\hline 199-D5-19 & A4576 & -- & 32 & 21.1 & - & $\mathrm{c}$ & Stable \\
\hline 199-D5-20 & $\mathrm{A} 4577$ & 9.3 & 11 & 49 & 130.3 & Increasing & Increasing \\
\hline 199-D5-37 & B8745 & -- & -- & 24 & 54.7 & Increasing & Increasing \\
\hline 199-D5-41 & $\mathrm{B} 8751$ & -- & - & $<5$ & 108.3 & Increasing & $c$ \\
\hline 199-D5-42 & $\mathrm{B} 8752$ & - & - & $<5$ & $<5$ & Stable & Stable \\
\hline 199-D5-44 & $\mathrm{B} 8754$ & $\cdots$ & - & $<5$ & $<5$ & Stable & Stable \\
\hline 199-D $8-4$ & A4579 & 53.5 & 61.4 & -- & 141 & c & Increasing \\
\hline 199-D8-5 & A4580 & 70 & 145.7 & - & -- & c & Increasing \\
\hline 199-D8-6 & A4585 & -- & 172 & -- & 95.4 & $\mathrm{c}$ & $c$ \\
\hline $199-D 8-53^{b}$ & A4581 & 89 & 185.2 & 100 & 131 & Increasing & Stable \\
\hline $199-\mathrm{D} 8-54 \mathrm{~A}^{\mathrm{b}}$ & A4582 & 112.9 & 277.9 & 115 & 233 & Increasing & Stable \\
\hline 199-D8-54B & A4583 & 41.3 & 4 & 7 & 9.5 & Increasing & Stable \\
\hline 199-D8-55 & A 4584 & 15.2 & - & 26 & 61.5 & Increasing & Stable \\
\hline 199-D8-68 & $\mathrm{B} 2772$ & 66.7 & 243 & 92 & 195.8 & Increasing & Stable \\
\hline 199-D8-69 & $\mathrm{B} 2773$ & 47.9 & 98.9 & 69 & 85.4 & Increasing & Stable \\
\hline 199-D8-70 & B2774 & 123.1 & 210.6 & 104 & 191.4 & Increasing & Stable \\
\hline 199-D8-71 & B2812 & 248.5 & 232 & 177.5 & 226 & Increasing & Stable \\
\hline $699-96-49$ & A5358 & -- & 37 & 41.8 & 45.8 & Stable & Stable \\
\hline $699-97-51 \mathrm{~A}$ & A5362 & 31.5 & 42 & $\cdots$ & 44.4 & Stable & Stable \\
\hline
\end{tabular}

anly filtered data were used.

${ }^{b}$ Extraction wells (2000 annual averages do not include the anomalously high chromium concentrations measured in all $100-\mathrm{D}$ and 100-H Area extraction wells on October 16, 2000).

'Not trended; insufficient data available. 
Table 2-11. 100-D Area Co-Contaminant Summary. (3 Pages)

\begin{tabular}{|c|c|c|c|c|c|c|}
\hline Well ID & Well Name & CY 1997 & CY 1998 & CY 1999 & CY 2000 & $\begin{array}{c}\text { Short-Term } \\
\text { Trend }^{\mathrm{a}}\end{array}$ \\
\hline \multicolumn{7}{|c|}{ Strontium-90 $(\mathrm{pCi} / \mathrm{L})$} \\
\hline A4569 & 199-D5-12 & 29.5 & 34.6 & 28.9 & --- & c \\
\hline A4570 & 199-D5-13 & $0.006(\mathrm{U})$ & -- & --- & -- & b \\
\hline A4571 & 199-D5-14 & $-0.1(\mathrm{U})$ & $\cdots$ & $\ldots$ & -- & b \\
\hline A4572 & 199-D5-15 & $1.5(\mathrm{~J})$ & $\cdots$ & $\cdots$ & --- & $\bar{b}$ \\
\hline A4573 & 199-D5-16 & $0.7(\mathrm{U})$ & $-\cdots$ & --- & $\cdots$ & $b$ \\
\hline A4574 & 199-D5-17 & $-0.15(\mathrm{U})$ & $\cdots$ & -- & --- & $\mathrm{b}$ \\
\hline A4575 & 199-D5-18 & $\ldots$ & $-\cdots$ & $-\cdots$ & $\ldots$ & b \\
\hline A4576 & 199-D5-19 & $\ldots$ & $0.9(\mathrm{~J})$ & $-\cdots$ & $\cdots$ & $b$ \\
\hline $\mathrm{A} 4577$ & 199-D5-20 & $0.1(\mathrm{U})$ & -- & --- & -- & $b$ \\
\hline B8745 & 199-D5-37 & $\ldots$ & $\ldots$ & $\cdots$ & -- & b \\
\hline $\mathrm{B} 8752$ & 199-D5-42 & $-\ldots$ & $\ldots$ & $\ldots$ & $-\cdots$ & $b$ \\
\hline B8754 & 199-D5-44 & --- & --- & $-\cdots$ & $-\cdots$ & $b$ \\
\hline B4579 & 199-D8-4 & $0.2(\mathrm{U})$ & $-\cdots$ & -- & $\cdots$ & $\mathrm{b}$ \\
\hline $\mathrm{A} 4580$ & 199-D8-5 & $0.002(\mathrm{U})$ & --- & --- & $\cdots$ & $\mathrm{b}$ \\
\hline $\mathrm{A} 4581$ & 199-D8-53 & $3.1(\mathrm{~J})$ & 4.9 & --- & 2.3 & Decreasing \\
\hline A4582 & 199-D8-54A & 3.0 & 5.6 & --- & 2.6 & Stable \\
\hline A4583 & 199-D8-54B & $-0.05(\mathrm{U})$ & --- & $\cdots$ & --- & $\mathrm{b}$ \\
\hline A4584 & 199-D8-55 & $1.2(J)$ & $-\cdots$ & --- & --- & $\mathrm{b}$ \\
\hline A4585 & \begin{tabular}{|l|} 
199-D8-6 \\
\end{tabular} & --- & --- & --- & $\ldots$ & $\mathrm{b}$ \\
\hline B2772 & 199-D8-68 & 35.2 & 11 & 7.2 & 9.6 & Increasing \\
\hline $\mathrm{B} 2773$ & 199-D8-69 & $0.8(\mathrm{~J})$ & $1.0(\mathrm{~J})$ & $0.7(\mathrm{~J})$ & 0.8 & Stable \\
\hline B2774 & 199-D8-70 & $0.8(\mathrm{~J})$ & $1.5(\mathrm{~J})$ & $2.1(\mathrm{~J})$ & $1.2(\mathrm{~J})$ & Decreasing \\
\hline B2812 & 199-D8-71 & $-\cdots$ & --- & --- & -- & $\mathrm{b}$ \\
\hline \multicolumn{7}{|c|}{ Tritium (pCi/L) } \\
\hline A4569 & 199-D5-12 & 14,300 & 30,350 & $\ldots$ & --- & $c$ \\
\hline A4570 & 199-D5-13 & $320^{d}$ & 415 & 443 & --- & $\mathrm{b}$ \\
\hline A4571 & 199-D5-14 & $\ldots$ & 2,770 & 6,000 & --- & $\mathrm{h}$ \\
\hline A4572 & 199-D5-15 & $156(\mathrm{U})$ & 16,650 & 862 & $-\cdots$ & ${ }^{b}$ \\
\hline A4573 & 199-D5-16 & $-\ldots$ & 13,800 & 14,300 & $-\cdots$ & $b$ \\
\hline A4574 & 199-D5-17 & 12,900 & 16,300 & 14,300 & $-\cdots$ & $\mathrm{b}$ \\
\hline A4575 & 199-D5-18 & $-\cdots$ & 16,000 & $-\cdots$ & $\ldots$ & $\mathrm{b}$ \\
\hline A4576 & 199-D5-19 & $\cdots$ & --- & 11,600 & --- & $\mathrm{b}$ \\
\hline A4577 & 199-D5-20 & --- & $-81.7(\mathrm{U})$ & $12.7(\mathrm{U})$ & -- & $b$ \\
\hline B8745 & 199-D5-37 & $\ldots$ & -- & $17.4(\mathrm{U})$ & $22.4(\mathrm{U})$ & Stable \\
\hline B8752 & 199-D5-42 & $-\cdots$ & --- & $7.7(\mathrm{U})$ & $131(\mathrm{U})$ & Stable \\
\hline B8754 & 199-D5-44 & -- & $\ldots$ & $12.5(\mathrm{U})$ & $41.3(\mathrm{U})$ & Stable \\
\hline $\mathrm{B} 4579$ & 199-D8-4 & $100.3(\mathrm{U})$ & $66.4(\mathrm{U})$ & 252 & 117 & Decreasing \\
\hline A4580 & \begin{tabular}{|l|}
$199-D 8-5$ \\
\end{tabular} & $88(\mathrm{U})$ & $127(\mathrm{U})$ & $256^{\mathrm{d}}$ & -- & $\mathrm{b}$ \\
\hline A4581 & 199-D8-53 & 3,000 & 6,455 & --- & 5,210 & Decreasing \\
\hline A4582 & 199-D8-54A & 2,483 & 8,600 & -- & 6,710 & Decreasing \\
\hline
\end{tabular}


Table 2-11. 100-D Area Co-Contaminant Summary. (3 Pages)

\begin{tabular}{|c|c|c|c|c|c|c|}
\hline Well ID & Well Name & CY 1997 & CY 1998 & CY 1999 & CY 2000 & $\begin{array}{c}\text { Short-Term } \\
\text { Trend }^{\mathrm{a}}\end{array}$ \\
\hline A4583 & 199-D8-54B & --- & $-35(U)$ & $87.1(\mathrm{U})$ & $7.3(\mathrm{U})$ & Stable \\
\hline A4584 & 199-D8-55 & $\ldots$ & $\cdots$ & $\ldots$ & $14.6(\mathrm{U})$ & $\mathrm{b}$ \\
\hline A4585 & 199-D8-6 & $169(\mathrm{U})$ & 358 & $\cdots$ & $\cdots$ & b \\
\hline B2772 & 199-D8-68 & 2,015 & 6,935 & 4,885 & 7,610 & Increasing \\
\hline B2773 & 199-D8-69 & 2,620 & 6,390 & 3,750 & 6,360 & Increasing \\
\hline B2774 & 199-D8-70 & 7,463 & 11,875 & 9,763 & 11,900 & Increasing \\
\hline $\mathrm{B} 2812$ & 199-D8-71 & -- & --- & $\ldots$ & 6,420 & $\mathrm{~b}$ \\
\hline \multicolumn{7}{|c|}{ Nitrate $(\mathrm{mg} / \mathrm{L})$} \\
\hline A4569 & 199-D5-12 & 90 & 95 & -- & -- & c \\
\hline A4570 & 199-D5-13 & 65 & 62 & 67 & $-\cdots$ & $\mathrm{b}$ \\
\hline A4571 & 199-D5-14 & 60 & 58 & 63 & -- & $\mathrm{b}$ \\
\hline A4572 & 199-D5-15 & 57 & 81 & 17 & -- & $\mathrm{b}$ \\
\hline A4573 & 199-D5-16 & 64 & 69 & 87 & --- & $b$ \\
\hline A4574 & 199-D5-17 & 74 & 89 & 83 & $-\cdots$ & $\mathrm{b}$ \\
\hline $\mathrm{A} 4575$ & 199-D5-18 & $\cdots$ & 91 & -- & --- & $b$ \\
\hline $\mathrm{A} 4576$ & 199-D5-19 & -- & 81 & 95 & $-\cdots$ & $\mathrm{b}$ \\
\hline A4577 & 199-D5-20 & 13 & 18 & 21 & $-\cdots$ & $\mathrm{b}$ \\
\hline B8745 & 199-D5-37 & $-\cdots$ & $\cdots$ & 15 & 14 & Stable \\
\hline B8752 & 199-D5-42 & --- & $\ldots$ & 21 & 26 & Increasing \\
\hline B8754 & 199-D5-44 & $\ldots$ & -- & 4 & 4 & $\mathrm{~b}$ \\
\hline B4579 & 199-D8-4 & 41 & 45 & 100 & 86 & Stable \\
\hline $\mathrm{A} 4580$ & 199-D8-5 & 10 & 25 & 36 & --- & $\mathrm{b}$ \\
\hline A4581 & 199-D8-53 & --- & --- & $\ldots$ & --- & $\mathrm{b}$ \\
\hline $\mathrm{A} 4582$ & 199-D8-54A & $-\cdots$ & -- & -- & $-\cdots$ & $\bar{b}$ \\
\hline A4583 & 199-D8-54B & 2 & 2 & 2 & 2 & Stable \\
\hline A4584 & 199-D8-55 & 8 & -- & $\ldots$ & 10 & $\mathrm{~b}$ \\
\hline A4585 & 199-D8-6 & 21 & 38 & 73 & 100 & Increasing \\
\hline B2772 & 199-D8-68 & $-\cdots$ & $-\cdots$ & -- & 57 & $\mathrm{~b}$ \\
\hline $\mathrm{B} 2773$ & 199-D8-69 & -- & $\cdots$ & $\ldots$ & $\cdots$ & $\mathrm{b}$ \\
\hline B2774 & 199-D8-70 & 29 & 38 & 43 & --- & $\mathrm{b}$ \\
\hline $\mathrm{B} 2812$ & 199-D8-71 & $\ldots$ & --- & 44 & --- & $\mathrm{b}$ \\
\hline \multicolumn{7}{|c|}{ Sulfate (mg/L) } \\
\hline A4569 & 199-D5-12 & 231 & 238 & -- & $\begin{array}{c}-- \\
-\cdots\end{array}$ & c \\
\hline A4570 & 199-D5-13 & 100 & 94 & 99 & -- & $b$ \\
\hline A4571 & 199-D5-14 & 81 & 92 & 111 & --- & $\mathrm{b}$ \\
\hline A4572 & 199-D5-15 & 97 & 158 & 33 & $-\cdots$ & $\mathrm{b}$ \\
\hline A4573 & 199-D5-16 & 112 & 133 & 150 & $\cdots$ & $\mathrm{b}$ \\
\hline A4574 & 199-D5-17 & 147 & 92 & 99 & $-\cdots$ & $\mathrm{b}$ \\
\hline $\mathrm{A} 4575$ & 199-D5-18 & $-\cdots$ & 148 & -- & $\ldots$ & $\mathrm{b}$ \\
\hline A4576 & 199-D5-19 & -- & 171 & 183 & -- & $\mathrm{b}$ \\
\hline A4577 & 199-D5-20 & 50 & 99 & 78 & $-\cdots$ & $\mathrm{b}$ \\
\hline B8745 & 199-D5-37 & --- & --- & 38 & 35 & Stable \\
\hline
\end{tabular}


Table 2-11. 100-D Area Co-Contaminant Summary. (3 Pages)

\begin{tabular}{|c|c|c|c|c|c|c|}
\hline Well ID & Well Name & CY 1997 & CY 1998 & CY 1999 & CY 2000 & $\begin{array}{c}\text { Short-Term } \\
\text { Trend }^{\mathrm{a}}\end{array}$ \\
\hline B8752 & 199-D5-42 & $\ldots$ & $-\cdots$ & 74 & 71 & Stable \\
\hline B8754 & 199-D5-44 & $-\ldots$ & $\cdots$ & 19 & 15 & Stable \\
\hline B4579 & 199-D8-4 & 76 & 88 & 114 & 118 & Stable \\
\hline A4580 & 199-D8-5 & 26 & 43 & 59 & --- & $\mathrm{b}$ \\
\hline A4581 & 199-D8-53 & $\ldots$ & --- & $\cdots$ & --- & $\mathrm{b}$ \\
\hline A4582 & 199-D8-54A & $\ldots$ & --- & -- & - & b \\
\hline A4583 & 199-D8-54B & 63 & 65 & 64 & 65.1 & Stable \\
\hline A4584 & 199-D8-55 & 19 & $\cdots$ & --- & 23 & $\mathrm{~b}$ \\
\hline A4585 & 199-D8-6 & 47 & 74 & 146 & 191 & Increasing \\
\hline B2772 & 199-D8-68 & $-\cdots$ & $-\cdots$ & $\ldots$ & 130 & $\mathrm{~b}$ \\
\hline B2773 & 199-D8-69 & $\ldots$ & $-\cdots$ & $\ldots$ & $-\cdots$ & $\mathrm{b}$ \\
\hline B2774 & 199-D8-70 & 64 & 89 & 100 & --- & b \\
\hline B2812 & 199-D8-71 & --- & $\cdots$ & 83 & $\cdots$ & $\mathrm{b}$ \\
\hline
\end{tabular}

"A trend is considered stable if there has been less than a $20 \%$ change between calendar years.

${ }^{b}$ Not trended; insufficient dala available.

${ }^{C_{\text {Well }}}$ decommissioned.

'One value used in calculating the average was a nondetect.

$\mathrm{J}=$ estimated

$\mathrm{U}=$ undetected

Table 2-12. 100-HR-3 (100-H Area) Water-Level Data and Results of the Drawdown/Buildup Analysis Used to Develop and Calibrate Numerical Groundwater Flow Models. (2 Pages)

\begin{tabular}{|c|c|c|c|c|c|c|c|c|}
\hline \multirow[b]{2}{*}{ Well } & \multicolumn{2}{|c|}{$\begin{array}{l}\text { Model Analysis } \\
\text { November } 2000\end{array}$} & \multirow{2}{*}{$\begin{array}{c}\text { Measured } \\
\text { Water-Level } \\
\text { Elevation } \\
\text { Nov 2000 } \\
\text { (m NA VD88) }\end{array}$} & \multirow{2}{*}{$\begin{array}{c}\text { Modeled } \\
\text { Water-Level } \\
\text { Elevation } \\
\text { Nov 2000 } \\
\text { (m NAVD88) }\end{array}$} & \multicolumn{4}{|c|}{$\begin{array}{c}\text { Drawdown/Buildup Analysis } \\
\text { January - March } 2000\end{array}$} \\
\hline & $\begin{array}{c}\text { Extraction } \\
\text { Rate } \\
\text { (L/min) }\end{array}$ & $\begin{array}{c}\text { Injection } \\
\text { Rate } \\
(\mathbf{L} / \mathbf{m i n})\end{array}$ & & & $\begin{array}{c}\text { Extraction } \\
\text { Rate } \\
(\mathrm{L} / \mathrm{min})\end{array}$ & $\begin{array}{c}\text { Injection } \\
\text { Rate } \\
(\mathrm{L} / \mathrm{min})\end{array}$ & $\begin{array}{l}\text { Drawdown } \\
(\mathbf{m})\end{array}$ & $\begin{array}{l}\text { Buildup } \\
\text { (m) }\end{array}$ \\
\hline 199-H3-2A & 74 & $-\cdots$ & 115.89 & 115.84 & 92 & -- & 0.1 & --- \\
\hline 199-H4-7 & 51 & $\ldots$ & 115.13 & 114.87 & 75 & $\cdots$ & 0.43 & -- \\
\hline 199-H4-11 & 76 & --- & 114.86 & 114.73 & 75 & $\cdots$ & 0.33 & -- \\
\hline 199-H4-12A & 51 & -- & 114.56 & 114.77 & 56 & $\ldots$ & 0.61 & -- \\
\hline 199-H4-15A & 57 & -- & 114.97 & 114.97 & 56 & -- & 0.33 & -- \\
\hline 199-H4-65 & 0 & $\ldots$ & N/A & 115.34 & 34 & -- & & \\
\hline $199-\mathrm{H} 3-3$ & $\cdots$ & 0 & 116.42 & 116.62 & --- & 0 & -- & 0.16 \\
\hline 199-H3-4 & $\ldots$ & 276 & $\mathrm{~N} / \mathrm{A}$ & 116.98 & -- & 315 & --- & 0.16 \\
\hline $199-\mathrm{H} 3-5$ & $\ldots$ & 274 & $\mathrm{~N} / \mathrm{A}$ & 117.07 & -- & 312 & $\ldots$ & 0.31 \\
\hline $199-\mathrm{H} 3-2 \mathrm{~B}$ & --- & -- & 115.94 & 115.93 & $\cdots$ & -- & 0.08 & -- \\
\hline 199-H4-4 & --- & --- & 115.18 & 115.18 & $\cdots$ & --- & 0.1 & --- \\
\hline 199-H4-5 & -- & -- & 115.21 & 115.17 & $\cdots$ & -- & 0.17 & -- \\
\hline $199-\mathrm{H} 4-8$ & -- & -- & 115.34 & 115.29 & -- & -- & 0.07 & $\ldots$ \\
\hline 199-H4-10 & --- & $\ldots$ & 115.25 & Fixed & -- & -- & 0.03 & $\ldots$ \\
\hline
\end{tabular}


Table 2-12. 100-HR-3 (100-H Area) Water-Level Data and Results of the Drawdown/Buildup Analysis Used to Develop and Calibrate Numerical Groundwater Flow Models. (2 Pages)

\begin{tabular}{|c|c|c|c|c|c|c|c|c|}
\hline \multirow[b]{2}{*}{ Well } & \multicolumn{2}{|c|}{$\begin{array}{l}\text { Model Analysis } \\
\text { November } 2000\end{array}$} & \multirow{2}{*}{$\begin{array}{c}\text { Measured } \\
\text { Water-Level } \\
\text { Elevation } \\
\text { Nov 2000 } \\
\text { (m NAVD88) }\end{array}$} & \multirow{2}{*}{$\begin{array}{c}\text { Modeled } \\
\text { Water-Level } \\
\text { Elevation } \\
\text { Nov 2000 } \\
\text { (m NAVD88) }\end{array}$} & \multicolumn{4}{|c|}{$\begin{array}{c}\text { Drawdown/Buildup Analysis } \\
\text { January - March } 2000\end{array}$} \\
\hline & $\begin{array}{c}\text { Extraction } \\
\text { Rate } \\
\text { (L/min) }\end{array}$ & $\begin{array}{c}\text { Injection } \\
\text { Rate } \\
(\mathrm{L} / \mathrm{min})\end{array}$ & & & $\begin{array}{c}\text { Extraction } \\
\text { Rate } \\
(\mathrm{L} / \mathrm{min})\end{array}$ & $\begin{array}{c}\text { Injection } \\
\text { Rate } \\
(\mathrm{L} / \mathrm{min})\end{array}$ & $\begin{array}{l}\text { Drawdown } \\
\text { (m) }\end{array}$ & $\begin{array}{l}\text { Buildup } \\
(\mathbf{m})\end{array}$ \\
\hline 199-H4-12B & $-\cdots$ & $\ldots$ & 115.17 & 114.97 & --- & --- & 0.12 & - \\
\hline $199-\mathrm{H} 4-15 \mathrm{~B}$ & --- & -- & 115.20 & 115.13 & -- & $\overline{---}$ & 0.12 & $\cdots$ \\
\hline 199-H4-63 & -- & -- & 115.05 & 115.22 & -- & $\ldots$ & 0.16 & $\ldots$ \\
\hline 199-H4-64 & -- & $\cdots$ & 115.28 & 115.17 & -- & $\cdots$ & 0.07 & -- \\
\hline 199-H4-49 & -- & --- & 116.28 & 116.27 & $\ldots$ &.-- & $-\cdots$ & 0.15 \\
\hline 199-H5-1A & -- & $-\cdots$ & 116.36 & 116.47 & -- & -- & -- & 0.09 \\
\hline 100-H River & -- & --- & 115.44 & $\cdots$ & -- & $\overline{--}$ & - & $\ldots$ \\
\hline
\end{tabular}

$\mathrm{N} / \mathrm{A}=$ not available

Table 2-13. CY 2000 Groundwater Monitoring Network and Sampling Frequency at 100-H Area.

\begin{tabular}{|l|c|c|l|}
\hline Type of Monitoring Location & $\begin{array}{c}\text { Number of } \\
\text { Locations }\end{array}$ & $\begin{array}{c}\text { Monitoring } \\
\text { Frequency }\end{array}$ & \multicolumn{1}{|c|}{ Comments } \\
\hline Compliance wells & 4 & Monthly & \\
\hline Extraction wells & 5 & Weekly & $\begin{array}{l}\text { Weekly samples collected and analyzed by the } \\
\text { on-site process operator. QC samples collected } \\
\text { quarterly for onsite and laboratory analysis. }\end{array}$ \\
\hline OU Monitoring wells & 28 & Quarterly & $\begin{array}{l}\text { See Appendix E for well list and requested } \\
\text { analyses. }\end{array}$ \\
\hline Sample tubes & 3 & Annually & Samples collected in the fall. \\
\hline Riverbank seepage & 2 & Annually & Samples collected in the fall. \\
\hline
\end{tabular}

Table 2-14. Construction Details and Use of Each of the 100-H Area Wells. (2 Pages)

\begin{tabular}{|c|c|c|c|c|c|}
\hline Well & $\begin{array}{c}\text { Date } \\
\text { Completed }\end{array}$ & $\begin{array}{c}\begin{array}{c}\text { Screened Interval } \\
\text { (ft/type) }\end{array} \\
\end{array}$ & $\begin{array}{l}\text { Depth to } \\
\text { Bottom }^{\text {a }}\end{array}$ & Water Level ${ }^{a, b}$ & Well Use \\
\hline 199-H3-1 & Aug 60 & 29-74/8-in. PCS & 69 & - & $M$ \\
\hline 199-H3-2A & Dec 86 & 36-51/6-in. SS & 51 & 40.69 & $\mathrm{E}$ \\
\hline 199-H3-2C & Dec 86 & 100-110/6-in. SS & 110 & 41.88 & $M$ \\
\hline 199-H3-3 & July 96 & $29-49 / 6$-in. SS & 52 & 39.56 & $I$ \\
\hline 199-H3-4 & July 96 & 21-46/6-in. SS & 49 & 33.52 & I \\
\hline 199-H3-5 & July 96 & 26-46/6-in. SS & 49 & 32.45 & $\mathrm{I}$ \\
\hline 199-H4-10 & Sept 86 & 23-38/6-in. SS & 38 & 30.60 & $\mathrm{M}$ \\
\hline 199-H4-11 & Oct 86 & $38-53 / 6$-in. SS & 53 & 43.88 & $E$ \\
\hline 199-H4-12A & Nov 86 & 33-48/6-in. SS & 48 & 40.87 & $\mathrm{E}$ \\
\hline 199-H4-12B & Nov 86 & 45-50/6-in. SS & 50 & 40.27 & $\mathrm{M}$ \\
\hline 199-H4-12C & Oct 86 & $72-82 / 6$-in. SS & 82 & 40.19 & $M$ \\
\hline
\end{tabular}


Table 2-14. Construction Details and Use of Each of the 100-H Area Wells. (2 Pages)

\begin{tabular}{|c|c|c|c|c|c|}
\hline Well & $\begin{array}{c}\text { Date } \\
\text { Completed }\end{array}$ & $\begin{array}{c}\text { Screened Interval } \\
\text { (ft/type) }\end{array}$ & $\begin{array}{l}\text { Depth to } \\
\text { Bottom }^{\text {a }}\end{array}$ & Water Level ${ }^{\mathrm{a}, \mathrm{b}}$ & Well Use \\
\hline 199-H4-13 & Nov 86 & $37-52 / 6$-in. SS & 52 & 45.73 & $M$ \\
\hline 199-H4-14 & Dec 86 & $38-53 / 6$-in. SS & 53 & 44.59 & $\mathrm{M}$ \\
\hline 199-H4-15A & Nov 86 & $27-42 / 6$-in. SS & 42 & 32.99 & $E$ \\
\hline 199-H4-15B & Nov 86 & $37-42 / 6$-in. SS & 42 & 33.43 & $M$ \\
\hline 199-H4-15CS & Dec 86 & $78-80 / 2$-in. SS & 80 & 33.89 & $M$ \\
\hline 199-H4-16 & Apr 87 & $42-57 / 6$-in. SS & 57 & 48.90 & $\mathrm{M}$ \\
\hline 199-H4-17 & May 87 & $35-45 / 6$-in. SS & 45 & 44.59 & $M$ \\
\hline 199-H4-18 & May 87 & $40-50 / 6$-in. SS & 50 & 47.36 & $M$ \\
\hline 199-H4-2 & June 52 & $367-382 / 2$-in. SS & 382 & -- & $\mathrm{M}$ \\
\hline 199-H4-3 & May 74 & 34-55/PCS & 57 & 46.02 & $\mathrm{M}$ \\
\hline 199-H4-4 & June 83 & 33-43/unknown & 49 & 40.62 & C \\
\hline 199-H4-45 & Mar 92 & $32-52 / 4$-in. SS & 52 & $38.90(11 / 98)$ & $\mathrm{M}$ \\
\hline $199-\mathrm{H} 4-46$ & Feb 92 & $39-59 / 4$-in. SS & 59 & 47.59 & $\mathrm{M}$ \\
\hline $199-\mathrm{H} 4-47$ & Feb 92 & 39-59/4-in. SS & 59 & 48.31 & $\mathrm{M}$ \\
\hline 199-H4-48 & Mar 92 & $39-59 / 4$-in. SS & 59 & 49.09 & $\mathrm{M}$ \\
\hline 199-H4-49 & Mar 92 & $38-53 / 4$-in. SS & 53 & 46.73 & $\mathrm{M}$ \\
\hline 199-H4-5 & May 83 & 32-42 unknown; 42-51 PCS & 55 & 42.39 & C \\
\hline 199-H4-6 & May 83 & 39-49 unknown & 51 & 43.09 & $\mathrm{M}$ \\
\hline 199-H4-63 & July 96 & 36-56/6-in. SS & 59 & 45.26 & $\mathrm{C}$ \\
\hline 199-H4-64 & July 96 & 22-42/6-in. SS & 45 & 36.66 & $\mathrm{C}$ \\
\hline 199-H4-65 & July 99 & $39-49 / 6$-in SS & 52 & $40.52(7 / 99)$ & $\mathrm{E}$ \\
\hline 199-H4-7 & Sept 86 & $38-53 / 6$-in. SS & 53 & 46.18 & $E$ \\
\hline 199-H4-8 & Sept 86 & 38-48/6-in. SS & 48 & 45.44 & $\mathrm{M}$ \\
\hline 199-H4-9 & Sept 86 & 36-46/6-in. SS & 46 & 43.83 & $\mathrm{M}$ \\
\hline 199-H5-1A & Mar 92 & 35-50/4-in. SS & 50 & 41.70 & $\mathrm{M}$ \\
\hline 199-H6-1 & Mar 92 & 29-55/4-in. SS & 55 & 42.78 & $\mathrm{M}$ \\
\hline 699-91-46A & Mar 92 & 23-43/4-in. SS & 43 & 32.45 & $\mathrm{M}$ \\
\hline $699-93-48 \mathrm{~A}$ & Feb 92 & 41-62/4-in. SS & 62 & $50.99(11 / 98)$ & $\mathrm{M}$ \\
\hline $699-96-43$ & Mar 92 & 32-48/4-in. SS & 48 & 41.42 & $\mathrm{M}$ \\
\hline $699-97-43$ & Oct 62 & 25-83/8-in. PCS & 80 & 41.95 & $\mathrm{M}$ \\
\hline
\end{tabular}

${ }^{2}$ Depths in feet below ground surface.

${ }^{b}$ Water levels measured on November 13, 2000, unless noted otherwise.

$\mathrm{C} \quad=$ compliance well

$\mathrm{E} \quad=$ extraction well

I = injection well

$\mathrm{M} \quad$ = monitoring well

PCS = perforated carbon-steel well casing

SS $=$ stainless-steel screen 
Table 2-15. Summary of Hexavalent Chromium Concentrations and Trends Within the 100-H Area Wells. (2 Pages)

\begin{tabular}{|c|c|c|c|c|c|c|c|}
\hline Well Name & $\begin{array}{l}\text { Well } \\
\text { ID }\end{array}$ & $\begin{array}{c}\text { CY } 1997 \\
\text { A verage } \\
(\mu \mathrm{g} / \mathrm{L})\end{array}$ & $\begin{array}{c}\text { CY } 1998 \\
\text { A verage } \\
(\mu \mathrm{g} / \mathrm{L})\end{array}$ & $\begin{array}{c}\text { CY } 1999 \\
\text { Average } \\
(\mu \mathrm{g} / \mathrm{L})\end{array}$ & $\begin{array}{c}\text { CY } 2000 \\
\text { Average } \\
(\mu \mathrm{g} / L)\end{array}$ & $\begin{array}{c}\text { Short- } \\
\text { Term } \\
\text { Trend }^{\mathrm{a}} \\
\end{array}$ & $\begin{array}{l}\text { Long-Term } \\
\text { Trend }^{\mathrm{b}}\end{array}$ \\
\hline 199-H3-1 & A4610 & 76.6 & - & - & $\ldots$ & d & $\mathrm{d}$ \\
\hline 199-H3-2A & A4612 & 59.1 & 20.2 & 17 & 8.4 & Decreasing & Decreasing \\
\hline 199-H3-2C & A4613 & 63.2 & 15.8 & 16.1 & - & d & Decreasing \\
\hline 199-H4-10 & A4614 & 17.5 & 25 & 27 & 24.5 & Stable & Increasing \\
\hline $199-\mathrm{H} 4-11^{\mathrm{c}}$ & A4615 & 61 & 88.6 & 51 & 38.3 & Decreasing & Decreasing \\
\hline $199-\mathrm{H} 4-12 \mathrm{~A}^{\mathrm{c}}$ & A4616 & 53.7 & 104.1 & 45 & 53 & Stable & Stable \\
\hline 199-H4-12B & A4617 & 62.5 & 98.5 & 58 & 68 & Stable & Stable \\
\hline 199-H4-12C & A4618 & 226 & 142.3 & 180 & 152.5 & Stable & Decreasing \\
\hline 199-H4-13 & A4619 & 43.4 & 59.5 & 44 & 34.5 & Decreasing & Decreasing \\
\hline 199-H4-14 & A4620 & 170.5 & 339 & 156 & 107 & Decreasing & Decreasing \\
\hline $199-\mathrm{H} 4-15 \mathrm{~A}^{\mathrm{c}}$ & A4621 & 42.8 & 61.2 & 50 & 44.9 & Stable & Stable \\
\hline 199-H4-15B & A4622 & 35 & 57.5 & 66 & 50 & Decreasing & Increasing \\
\hline 199-H4-15CS & A4625 & 78 & 95 & 99 & 107 & Stable & Increasing \\
\hline 199-H4-16 & A4626 & 71 & 49 & 25 & 9.5 & Decreasing & Decreasing \\
\hline 199-H4-17 & A4627 & 44 & 54 & 44 & 34.5 & Decreasing & Decreasing \\
\hline 199-H4-18 & A4628 & 97.8 & 177.5 & 121 & 28.5 & Decreasing & Decreasing \\
\hline 199-H4-3 & A4629 & 166.5 & 215.5 & 165 & 130 & Decreasing & Decreasing \\
\hline 199-H4-4 & A4630 & 55.2 & 144.5 & 44 & 71.4 & Increasing & Increasing \\
\hline $199-\mathrm{H} 4-45$ & A4631 & 34.8 & 47 & 37 & 24.5 & Decreasing & Decreasing \\
\hline 199-H4-46 & A4632 & 45 & 33.5 & 22 & 12.5 & Decreasing & Decreasing \\
\hline 199-H4-47 & A4633 & 85.6 & 29.6 & 12.1 & $4.1(U)$ & Decreasing & Decreasing \\
\hline 199-H4-48 & A4634 & 101.9 & 86 & 19 & 10.5 & Decreasing & Decreasing \\
\hline 199-H4-49 & A4635 & 40.2 & 21 & 8 & 14 & Increasing & Decreasing \\
\hline 199-H4-5 & A4636 & 73.8 & 132.6 & 89 & 70.3 & Decreasing & Stable \\
\hline 199-H4-6 & A4637 & 54.7 & 38 & 25 & 22.5 & Stable & Decreasing \\
\hline 199-H4-63 & B2776 & 47.8 & 71.7 & 43 & 59.2 & Increasing & Increasing \\
\hline 199-H4-64 & B2777 & 32.6 & 56.1 & 35 & 42.2 & Stable & Increasing \\
\hline $199-\mathrm{H} 4-65^{\circ}$ & B8759 & -- & - & -- & 60 & $\mathrm{~d}$ & $\bar{d}$ \\
\hline $199-\mathrm{H} 4-7^{c}$ & A4638 & 118.3 & 116.9 & 59 & 45.3 & Decreasing & Decreasing \\
\hline 199-H4-8 & A4639 & 116.5 & 95.3 & 58 & 43.5 & Decreasing & Decreasing \\
\hline 199-H4-9 & A4640 & 139 & -- & 115 & 107 & Stable & Decreasing \\
\hline 199-H5-1A & A4641 & 54.5 & 15 & 6 & 9.5 & Increasing & Decreasing \\
\hline 199-H6-1 & A4642 & 38.8 & 37.6 & 39.6 & 37.7 & Stable & Stable \\
\hline $699-93-48 \mathrm{~A}$ & A5356 & 14.6 & -- & 13.2 & $\ldots$ & d & Stable \\
\hline $699-96-43$ & A5357 & 82.9 & 102 & - & 104 & Stable & Increasing \\
\hline
\end{tabular}


Table 2-15. Summary of Hexavalent Chromium Concentrations and Trends Within the 100-H Area Wells. (2 Pages)

\begin{tabular}{|c|c|c|c|c|c|c|c|}
\hline Well Name & $\begin{array}{l}\text { Well } \\
\text { ID }\end{array}$ & $\begin{array}{c}\text { CY } 1997 \\
\text { Average } \\
(\mu \mathrm{g} / \mathrm{L})\end{array}$ & $\begin{array}{c}\text { CY } 1998 \\
\text { Average } \\
(\mu \mathrm{g} / \mathrm{L})\end{array}$ & $\begin{array}{c}\text { CY } 1999 \\
\text { Average } \\
(\mu \mathrm{g} / \mathrm{L})\end{array}$ & $\begin{array}{c}\text { CY } 2000 \\
\text { Average } \\
(\mu \mathrm{g} / \mathrm{L})\end{array}$ & $\begin{array}{c}\text { Short- } \\
\text { Term } \\
\text { Trend }^{\mathrm{a}} \\
\end{array}$ & $\begin{array}{l}\text { Long-Term } \\
\text { Trend }^{\mathrm{b}}\end{array}$ \\
\hline 699-97-43 & A5360 & 78.2 & 87.9 & 91.8 & 102 & Stable & Increasing \\
\hline $699-97-51 \mathrm{~A}$ & A5362 & 31.5 & 42 & 41.8 & 44.4 & Stable & Increasing \\
\hline
\end{tabular}

Note: Only filtered data were used. It is assumed that for wells that were not sampled specifically for hexavalent chromium, filtered total chromium is equivalent to a hexavalent chromium sample.

${ }^{a}$ Short-term trends are a comparison of CY 1999 to CY 2000 data (or most recent two CYs).

${ }^{b}$ Long-term trends are a comparison of CY 1997 to CY 2000 data (oldest CY data to newest CY data).

${ }^{c}$ Extraction wells.

${ }^{\mathrm{N}}$ Not trended; insufficient data available.

Bolded values are above the RAO of $22 \mu \mathrm{g} / \mathrm{L}$ for hexavalent chromium.

Table 2-16. 100-H Area Co-Contaminant Summary. (4 Pages)

\begin{tabular}{|l|l|c|c|c|c|l|}
\hline Well ID & Well Name & $\begin{array}{c}\text { CY 1997 } \\
\text { Average }\end{array}$ & $\begin{array}{c}\text { CY 1998 } \\
\text { Average }\end{array}$ & $\begin{array}{c}\text { CY 1999 } \\
\text { Average }\end{array}$ & $\begin{array}{c}\text { CY 2000 } \\
\text { Average }\end{array}$ & $\begin{array}{c}\text { Short-Term } \\
\text { Trend }^{\text {a }}\end{array}$ \\
\hline Strontium-90 (pCi/L) & \multicolumn{7}{|l|}{} \\
\hline A4612 & $199-\mathrm{H} 3-2 \mathrm{~A}^{\mathrm{b}}$ & $0.11(\mathrm{U})$ & $-0.06(\mathrm{U})$ & $-0.12) \mathrm{U})$ & $-0.16(\mathrm{U})$ & Stable \\
\hline A4615 & $199-\mathrm{H} 4-11^{\mathrm{b}}$ & $\mathbf{2 4 . 3 0}$ & $\mathbf{2 8 . 4 0}$ & $\mathbf{2 5 . 5 0}$ & $\mathbf{1 9}$ & Decreasing \\
\hline A4616 & $199-\mathrm{H} 4-12 \mathrm{~A}^{\mathrm{b}}$ & 0.49 & $\mathbf{1 2 . 6 6}$ & 0.28 & $0.17(\mathrm{U})$ & Decreasing \\
\hline A4621 & $199-\mathrm{H} 4-15 \mathrm{~A}^{\mathrm{b}}$ & $0.03(\mathrm{U})$ & $-0.06(\mathrm{U})$ & $-0.13(\mathrm{U})$ & $-0.12(\mathrm{U})$ & Stable \\
\hline A4626 & $199-\mathrm{H} 4-16$ & -- & -- & $\mathbf{1 2 . 8 0}$ & & Not sampled \\
\hline A4628 & $199-\mathrm{H} 4-18$ & 4.023 & 3.37 & 3.37 & 5.13 & Increasing \\
\hline A4629 & $199-\mathrm{H} 4-3$ & -- & -- & $1.00(\mathrm{U})$ & -- & Not sampled \\
\hline A4630 & $199-\mathrm{H} 4-4$ & $\mathbf{1 0 . 8 0}$ & 5.49 & 5.21 & 0.54 & Decreasing \\
\hline A4631 & $199-\mathrm{H} 4-45$ & -- & $\mathbf{1 9 . 3 0}$ & $\mathbf{1 9 . 2 0}$ & $\mathbf{1 8 . 5 0}$ & Stable \\
\hline A4632 & $199-\mathrm{H} 4-46$ & -- & - & 2.47 & 2.29 & Stable \\
\hline A4633 & $199-\mathrm{H} 4-47$ & -- & 0.19 & $0.06(\mathrm{U})$ & -- & Not sampled \\
\hline A4636 & $199-\mathrm{H} 4-5$ & $0.35(\mathrm{U})$ & $0.04(\mathrm{U})$ & $-0.08(\mathrm{U})$ & $0.82(\mathrm{U})$ & Stable \\
\hline B2776 & $199-\mathrm{H} 4-63$ & $\mathbf{4 7 . 7 0}$ & $\mathbf{4 7 . 6 0}$ & $\mathbf{3 3 . 5 5}$ & $\mathbf{3 8 . 0 0}$ & Stable \\
\hline B2777 & $199-\mathrm{H} 4-64$ & $0.23(\mathrm{U})$ & $0.12(\mathrm{U})$ & $-0.05(\mathrm{U})$ & $-0.16(\mathrm{U})$ & Stable \\
\hline B8759 & $199-\mathrm{H} 4-65^{\mathrm{b}}$ & -- & -- & -- & 3.6 & $\begin{array}{l}\text { First time } \\
\text { sampled }\end{array}$ \\
\hline A4638 & $199-\mathrm{H} 4-7^{\mathrm{b}}$ & $0.32(\mathrm{U})$ & $0.24(\mathrm{U})$ & $0.06(\mathrm{U})$ & $-0.09(\mathrm{U})$ & Stable \\
\hline A4642 & $199-\mathrm{H} 6-1$ & -- & $\mathbf{9 . 0 4}$ & $\mathbf{9 . 4 7}$ & 7.44 & Decreasing \\
\hline Tritium (pCi/L) & & & & & \\
\hline A4610 & $199-\mathrm{H} 3-1$ & 8870 & -- & -- & -- & Not sampled \\
\hline A4612 & $199-\mathrm{H} 3-2 \mathrm{~A}^{\mathrm{b}}$ & 3547 & 3482 & 4115 & 3435 & Stable \\
\hline A4613 & $199-\mathrm{H} 3-2 \mathrm{C}$ & 3070 & 1410 & 2075 & -- & Not sampled \\
\hline A4614 & $199-\mathrm{H} 4-10$ & 799 & 3190 & 2230 & 1630 & Decreasing \\
\hline A4615 & $199-\mathrm{H} 4-11^{\mathrm{b}}$ & 1275 & 3105 & 1780 & 1420 & Decreasing \\
\hline A4616 & $199-\mathrm{H} 4-12 \mathrm{~A}^{\mathrm{b}}$ & $\mathbf{9 5 8}$ & 1605 & 447 & 857 & Increasing \\
\hline A4618 & $199-\mathrm{H} 4-12 \mathrm{C}$ & -- & 40 & 80 & 31 & Decreasing \\
\hline
\end{tabular}


Table 2-16. 100-H Area Co-Contaminant Summary. (4 Pages)

\begin{tabular}{|c|c|c|c|c|c|c|}
\hline Well ID & Well Name & $\begin{array}{l}\text { CY } 1997 \\
\text { Average } \\
\end{array}$ & $\begin{array}{l}\text { CY } 1998 \\
\text { A verage } \\
\end{array}$ & $\begin{array}{l}\text { CY } 1999 \\
\text { Average } \\
\end{array}$ & $\begin{array}{l}\text { CY } 2000 \\
\text { A verage } \\
\end{array}$ & $\begin{array}{c}\text { Short-Term } \\
\text { Trend }^{\mathrm{a}}\end{array}$ \\
\hline A4619 & 199-H4-13 & 1380 & 4570 & 3660 & 3610 & Stable \\
\hline A4620 & 199-H4-14 & - & 3570 & - & 3590 & Not sampled \\
\hline A4621 & $199-\mathrm{H} 4-15 \mathrm{~A}^{\mathrm{b}}$ & 1157 & 1855 & 2460 & 1700 & Decreasing \\
\hline $\mathrm{A} 4626$ & 199-H4-16 & -- & 6630 & - & 2260 & Not sampled \\
\hline A4627 & $199-\mathrm{H} 4-17$ & - & 3600 & - & -- & Not sampled \\
\hline $\mathrm{A} 4628$ & 199-H4-18 & 2810 & 3770 & 3795 & 3450 & Stable \\
\hline A4629 & $199-\mathrm{H} 4-3$ & -- & 2640 & 3005 & 3390 & Stable \\
\hline $\mathrm{A} 4630$ & 199-H4-4 & 1770 & 2280 & 1140 & 2070 & Increasing \\
\hline A4631 & 199-H4-45 & 2490 & 5400 & 5440 & 4710 & Stable \\
\hline A4632 & 199-H4-46 & -- & 6370 & -- & 3995 & Not sampled \\
\hline $\mathrm{A} 4633$ & 199-H4-47 & 4200 & 5460 & 2395 & -- & Not sampled \\
\hline A4634 & 199-H4-48 & 6110 & -- & 4450 & - & Not sampled \\
\hline A4635 & 199-H4-49 & 9130 & - & 3860 & -- & Not sampled \\
\hline A4636 & 199-H4-5 & 2590 & 2790 & 2630 & - & Not sampled \\
\hline $\mathrm{A} 4637$ & 199-H4-6 & -- & 4490 & - & 3780 & Not sampled \\
\hline B2776 & 199-H4-63 & 1390 & - & 3130 & 3020 & Stable \\
\hline B2777 & 199-H4-64 & - & 2700 & 1860 & 2200 & Stable \\
\hline B8759 & $199-\mathrm{H} 4-65^{b}$ & -- & -- & -- & 3780 & $\begin{array}{l}\text { First time } \\
\text { sampled }\end{array}$ \\
\hline $\mathrm{A} 4638$ & $199-\mathrm{H} 4-7^{b}$ & 3040 & 3205 & 3400 & 3610 & Stable \\
\hline A4639 & 199-H4-8 & -- & 3070 & - & 3450 & Not sampled \\
\hline $\mathrm{A} 4640$ & 199-H4-9 & 2100 & -- & 2720 & -- & Not sampled \\
\hline A 4641 & 199-H5-1A & 7400 & - & 3020 & $\cdots$ & Not sampled \\
\hline $\mathrm{A} 4642$ & 199-H6-1 & 4030 & 5890 & 5580 & 5740 & Stable \\
\hline A5356 & 699-93-48A & -- & - & 1500 & -- & Not sampled \\
\hline A5357 & $699-96-43$ & -- & 8370 & - & -- & Not sampled \\
\hline A5360 & $699-97-43$ & 5510 & 5270 & 5543.3 & 5880 & Stable \\
\hline \multicolumn{7}{|c|}{ Nitrate $(\mathrm{mg} / \mathrm{L})$} \\
\hline $\mathrm{A} 4612$ & $199-\mathrm{H} 3-2 \mathrm{~A}^{\mathrm{b}}$ & - & 38 & 36 & 34.7 & Stable \\
\hline $\mathrm{A} 4613$ & $199-\mathrm{H} 3-2 \mathrm{C}$ & -- & -- & 22 & -- & Not sampled \\
\hline A4614 & 199-H4-10 & - & - & 22 & 16 & Decreasing \\
\hline $\mathrm{A} 4615$ & 199-H4-11 b & -- & 44 & 31 & 21.5 & Decreasing \\
\hline A 4616 & $199-\mathrm{H} 4-12 \mathrm{~A}^{\mathrm{b}}$ & -- & 84 & 5.1 & 14.2 & Increasing \\
\hline A4618 & $199-\mathrm{H} 4-12 \mathrm{C}$ & -- & -- & 6 & 5.4 & Stable \\
\hline A4619 & 199-H4-13 & 51.8 & -- & 57.7 & 39 & Decreasing \\
\hline $\mathrm{A} 4620$ & 199-H4-14 & -- & 32.9 & -- & 35 & Not sampled \\
\hline $\mathrm{A} 4621$ & $199-\mathrm{H} 4-15 \mathrm{~A}^{\mathrm{b}}$ & - & 26 & 29 & $-\cdots$ & Not sampled \\
\hline A4626 & 199-H4-16 & - & -- & -- & 23 & Not sampled \\
\hline A4627 & 199-H4-17 & - & - & -- & 39 & Not sampled \\
\hline $\mathrm{A} 4628$ & 199-H4-18 & -- & -- & 47 & 38 & Decreasing \\
\hline A 4629 & 199-H4-3 & -- & - & 380 & 120 & Decreasing \\
\hline A4630 & 199-H4-4 & - & -- & 270 & 150 & Decreasing \\
\hline
\end{tabular}


Table 2-16. 100-H Area Co-Contaminant Summary. (4 Pages)

\begin{tabular}{|c|c|c|c|c|c|c|}
\hline Well ID & Well Name & $\begin{array}{l}\text { CY } 1997 \\
\text { Average } \\
\end{array}$ & $\begin{array}{l}\text { CY } 1998 \\
\text { Average }\end{array}$ & $\begin{array}{l}\text { CY } 1999 \\
\text { Average } \\
\end{array}$ & $\begin{array}{l}\text { CY } 2000 \\
\text { Average } \\
\end{array}$ & $\begin{array}{c}\text { Short-Term } \\
\text { Trend }^{\mathrm{a}} \\
\end{array}$ \\
\hline A4631 & $199-\mathrm{H} 4-45$ & - & -- & 60 & 46 & Decreasing \\
\hline A4632 & 199-H4-46 & - & - & -- & 37 & Not sampled \\
\hline A4633 & $199-\mathrm{H} 4-47$ & -- & -- & 23 & - & Not sampled \\
\hline A4634 & $199-\mathrm{H} 4-48$ & -- & - & 40 & -- & Not sampled \\
\hline A4635 & 199-H4-49 & - & - & 27 & -- & Not sampled \\
\hline A4636 & 199-H4-5 & -- & -- & 63 & 44 & Decreasing \\
\hline A4637 & $199-\mathrm{H} 4-6$ & - & -- & - & 41 & Not sampled \\
\hline $\mathrm{B} 2776$ & 199-H4-63 & - & -- & 85 & 37 & Decreasing \\
\hline $\mathrm{B} 2777$ & 199-H4-64 & -- & -- & 40 & 35 & Stable \\
\hline B8759 & $199-\mathrm{H} 4-65^{\mathrm{b}}$ & -- & - & -- & 82 & $\begin{array}{l}\text { First time } \\
\text { sampled }\end{array}$ \\
\hline A4638 & $199-\mathrm{H}_{4}-7^{\mathrm{b}}$ & -- & 36 & 44 & 52.6 & Stable \\
\hline A4639 & 199-H4-8 & -- & -- & - & 44 & Not sampled \\
\hline A4640 & 199-H4-9 & -- & - & 190 & -- & Not sampled \\
\hline A4641 & 199-II5-1A & -- & - & 26 & -- & Not sampled \\
\hline $\mathrm{A} 4642$ & 199-H6-1 & - & - & 65 & 58 & Stable \\
\hline A5356 & 699-93-48A & -- & -- & 16 & - & Not sampled \\
\hline A5360 & $699-97-43$ & -- & - & 31 & - & Not sampled \\
\hline \multicolumn{7}{|c|}{ Technetium-99 (pCi/L) } \\
\hline $\mathrm{A} 4612$ & $199-\mathrm{H} 3-2 \mathrm{~A}^{\mathrm{b}}$ & $1.66(\mathrm{U})$ & $0.39(\mathrm{U})$ & 30.30 & 39.80 & Increasing \\
\hline A4613 & 199-H3-2C & $3.98(\mathrm{U})$ & $-0.72(\mathrm{U})$ & -- & -- & Not sampled \\
\hline A4615 & $199-\mathrm{H} 4-11^{\mathrm{b}}$ & 53.80 & 41.77 & 43.2 & 60.4 & Increasing \\
\hline A4616 & $199-\mathrm{H} 4-12 \mathrm{~A}^{\mathrm{b}}$ & 274.76 & 241.5 & 82.2 & 78.65 & Stable \\
\hline A4618 & $199-\mathrm{H} 4-12 \mathrm{C}$ & $2.64(U)$ & $2.5(\mathrm{U})$ & $-2.10(\mathrm{U})$ & -- & Not sampled \\
\hline A4621 & $199-\mathrm{H} 4-15 \mathrm{~A}^{\mathrm{b}}$ & $4.87(U)$ & $4.87(\mathrm{U})$ & 9.55 & 19.75 & Increasing \\
\hline A4628 & 199-H4-18 & 143.06 & 11.0 & 25.03 & 11.8 & Decreasing \\
\hline A4629 & 199-H4-3 & 1376 & 187 & 1070 & 272 & Decreasing \\
\hline A4630 & 199-H4-4 & 483.34 & 652.0 & 271.67 & 239.31 & Stable \\
\hline A4636 & 199-H4-5 & 1130 & 90.2 & 60.15 & 33.4 & Decreasing \\
\hline A4637 & 199-H4-6 & $0.91(\mathrm{U})$ & $\ldots$ & - & -- & Not sampled \\
\hline $\mathrm{B} 2776$ & $199-\mathrm{H} 4-63$ & 30.1 & $6.1(\mathrm{U})$ & 8.1 & $6.14(\mathrm{U})$ & Decreasing \\
\hline $\mathrm{B} 2777$ & 199-H4-64 & $7.81(\mathrm{U})$ & $0.4(U)$ & $-4.66(U)$ & $-0.91(\mathrm{U})$ & Stable \\
\hline B8759 & $199-\mathrm{H} 4-65^{\mathrm{b}}$ & - & -- & -- & 166 & $\begin{array}{l}\begin{array}{l}\text { First time } \\
\text { sampled }\end{array} \\
\end{array}$ \\
\hline A4638 & $199-\mathrm{H} 4-7^{b}$ & 2080 & 23.82 & 17.64 & 35.94 & Increasing \\
\hline $\mathrm{A} 4640$ & 199-H4-9 & 83.14 & $-\cdots$ & 616 & 198 & Decreasing \\
\hline \multicolumn{7}{|c|}{ Uranium $(\mu \mathrm{g} / \mathrm{L})$} \\
\hline $\mathrm{A} 4612$ & $199-\mathrm{H} 3-2 \mathrm{~A}^{\mathrm{b}}$ & 4.12 & 3.27 & 1.95 & -- & Not sampled \\
\hline $\mathrm{A} 4615$ & $199-\mathrm{H} 4-11^{\mathrm{b}}$ & 8.54 & 9.62 & 6.12 & - & \begin{tabular}{|l|} 
Not sampled \\
\end{tabular} \\
\hline A4616 & $199-\mathrm{H} 4-12 \mathrm{~A}^{\mathrm{b}}$ & 20.97 & 20.45 & 5.38 & 15.8 & Increasing \\
\hline A4618 & $199-\mathrm{H} 4-12 \mathrm{C}$ & 1.36 & 1.67 & 1.67 & $\ldots$ & Not sampled \\
\hline $\mathrm{A} 4621$ & $199-\mathrm{H} 4-15 \mathrm{~A}^{\mathrm{b}}$ & 1.67 & 2.48 & 2.18 & 2.04 & Stable \\
\hline
\end{tabular}


Table 2-16. 100-H Area Co-Contaminant Summary. (4 Pages)

\begin{tabular}{|c|c|c|c|c|c|c|}
\hline Well ID & Well Name & $\begin{array}{l}\text { CY } 1997 \\
\text { A verage }\end{array}$ & $\begin{array}{l}\text { CY } 1998 \\
\text { Average }\end{array}$ & $\begin{array}{l}\text { CY } 1999 \\
\text { A verage }\end{array}$ & $\begin{array}{l}\text { CY } 2000 \\
\text { Average }\end{array}$ & $\begin{array}{c}\text { Short-Term } \\
\text { Trend }^{\mathrm{a}}\end{array}$ \\
\hline A4628 & 199-H4-18 & 18.57 & 7.33 & 7.33 & 5.16 & Decreasing \\
\hline A4629 & 199-H4-3 & 126.8 & 21.3 & 157 & 49.3 & Decreasing \\
\hline A4630 & 199-H4-4 & 40.61 & 55.55 & 21.43 & 22.98 & Stable \\
\hline A4636 & 199-H4-5 & 27.10 & 11.10 & 7.46 & 5.41 & Decreasing \\
\hline A4637 & 199-H4-6 & 9.14 & -- & - & -- & Not sampled \\
\hline B2776 & 199-H4-63 & 5.27 & 4.85 & 5.60 & 4.82 & Stable \\
\hline $\mathrm{B} 2777$ & 199-H4-64 & 2.83 & 2.96 & 2.42 & 2.77 & Stable \\
\hline B8759 & $199-\mathrm{H} 4-65^{b}$ & - & -- & - & -- & Not sampled \\
\hline A4638 & $199-\mathrm{H} 4-7^{b}$ & 106 & 5.19 & 3.88 & 3.16 & Stable \\
\hline $\mathrm{A} 4640$ & 199-H4-9 & 10.04 & $\ldots$ & 25.3 & 13.3 & Decreasing \\
\hline
\end{tabular}

${ }^{2}$ Short-term trend evaluated by comparing CY 1999 to CY 2000 data. Trends are considered stable if there is less than a $20 \%$ change between CY 1999 and CY 2000. Short-term trend evaluation is not attempted if the well was not sampled during CY 2000.

${ }^{\mathrm{b}}$ Denotes an extraction well.

Bolded values are above the MCLs for constituents: $8 \mathrm{pCi} / \mathrm{L}$ for strontium- $90,20,000 \mathrm{pCi} / \mathrm{L}$ for tritium, $45 \mathrm{mg} / \mathrm{L}$ for nitrate, $900 \mathrm{pCi} / \mathrm{L}$ for technetium-99, and $20 \mu \mathrm{g} / \mathrm{L}$ for total uranium

Table 2-17. Quality Control Results, 100-D and 100-H Area. (2 Pages)

\begin{tabular}{|c|c|c|c|c|}
\hline Sample Number & Value & Sample Number & Value & RPD (\%) \\
\hline \multicolumn{5}{|c|}{ Field Replicates } \\
\hline \multicolumn{5}{|c|}{ Hexavalent Chromium $(\mu \mathrm{g} / \mathrm{L})$} \\
\hline B0YT38 & 468 & B0YT39 & 469 & 0.2 \\
\hline B0Y9R4 & 165 & B0Y9R5 & 175 & 5.9 \\
\hline B10LB3 & 351 & B10LB4 & 351 & 0.0 \\
\hline B0YT08 & 102 & B0YT09 & 104 & 1.9 \\
\hline B10WL0 & 144 & B10WL1 & 143 & 0.7 \\
\hline B0YWP4 & 49 & B0YWP8 & 50 & 2.0 \\
\hline B0YPW7 & 33 & B10RB3 & 42 & 24.0 \\
\hline B10L67 & 79 & B10L68 & 78 & 1.3 \\
\hline B0YJ83 & 11 & B0YJ84 & 11 & 0.0 \\
\hline B0YJ92 & 24 & B0YJ93 & 24 & 0.0 \\
\hline B0Y9L7 & 74 & B0Y9L8 & 74 & 0.0 \\
\hline B0Y6D3 & 47 & B0Y6D4 & 45 & 4.3 \\
\hline B0X641 & 50 & B0X642 & 48 & 4.1 \\
\hline B10380 & 39 & B10381 & 38 & 2.6 \\
\hline B10L87 & 44 & B10L91 & 44 & 0.0 \\
\hline B0Y435 & 63 & B0Y436 & 66 & 4.7 \\
\hline B0YJ85 & 7 & B0YJ86 & 7 & 0.0 \\
\hline
\end{tabular}


Table 2-17. Quality Control Results, 100-D and 100-H Area. (2 Pages)

\begin{tabular}{|c|c|c|c|c|}
\hline Sample Number & Value & Sample Number & Value & RPD (\%) \\
\hline \multicolumn{5}{|c|}{ Field/Offsite Laboratory Splits } \\
\hline Hexavalent Chromium $(\mu \mathrm{g} / \mathrm{L})$ & 7 & B0YJ75 & 4 & -54.5 \\
\hline B0YJ74 & 7 & B0X639 & 32 & -9.0 \\
\hline B0X638 & 35 & B0Y6C9 & 19 & -14.6 \\
\hline B0Y6C8 & 22 & B10LH2 & 29 & -15.9 \\
\hline B10LH0 & 34 & B0XCF7 & 68 & -1.5 \\
\hline B0XCF6 & 69 & B10LH8 & 9 & -43.5 \\
\hline B10LH6 & 14 & B0YJ89 & 8 & -31.6 \\
\hline B0YJ88 & 11 & B10WK5 & 75 & -1.3 \\
\hline B10WK4 & 76 & B0Y9L3 & 10 & -66.7 \\
\hline B0Y9L2 & 20 & Offsite Laboratory Replicates \\
\hline Total Chromium $(\mu \mathrm{g} / \mathrm{L})$ & & & & \\
\hline B10L92 & 82.5 & B10L98 & 75.2 & 9.3 \\
\hline B10L97 & 101 & B10LB0 & 93 & 8.2 \\
\hline B10M42 & 349 & B10M44 & 349 & 0.0 \\
\hline B10LH2 & 28.3 & B10LH4 & 29.2 & 3.1 \\
\hline B10LH3 & 37 & B10LH5 & 29.2 & 23.6 \\
\hline B10LH8 & 11.6 & B10LJ0 & 10.5 & 10.0 \\
\hline B10LH9 & 13.6 & B10LJ1 & 11.7 & 15.0 \\
\hline B10L90 & 71.1 & B10L94 & 81.5 & 13.6 \\
\hline B10L89 & 56.7 & B10L93 & 65.4 & 14.3 \\
\hline B10L90 & 2.77 & B10L94 & 2.77 & 0 \\
\hline
\end{tabular}

Table 2-18. Operational Performance Summary for the 100-HR-3 Pump-and-Treat System. (2 Pages)

\begin{tabular}{|l|l|}
\hline \multicolumn{1}{|c|}{ Operational Performance Criteria } & \multicolumn{1}{c|}{ 100-HR-3 OU Result } \\
\hline $\begin{array}{l}\text { Treatment system will reduce the effluent } \\
\text { chromium concentrations of the groundwater } \\
\text { to the maximum extent practicable. No } \\
\text { chromium discharge above } 50 \mu \mathrm{g} / \mathrm{L} .\end{array}$ & $\begin{array}{l}\text { 1. } \begin{array}{l}\text { The average } 100 \text {-H Area influent chromium } \\
\text { concentration was } 34 \mu \mathrm{g} / \mathrm{L} \text { and the average } 100-\mathrm{D} \\
\text { Area influent concentration was } 247 \mu \mathrm{g} / \mathrm{L} .\end{array} \\
\text { During the period, the highest chromium } \\
\text { concentration in the treatment effluent was } 46 \mu \mathrm{g} / \mathrm{L}, \\
\text { and the average concentration was } 7 \mu \mathrm{g} / \mathrm{L} . \\
\text { Overall, the removal efficiency of the system } \\
\text { exceeds } 93 \% .\end{array}$ \\
\hline
\end{tabular}




\section{Table 2-18. Operational Performance Summary for the 100-HR-3 Pump-and-Treat System. (2 Pages)}

\begin{tabular}{|c|c|}
\hline Operational Performance Criteria & 100-HR-3 OU Result \\
\hline $\begin{array}{l}\text { Design should provide for flexibility } \\
\text { following startup to accommodate changes } \\
\text { in plume characteristics or a different } \\
\text { understanding of actual or perceived } \\
\text { responses of the aquifer/plume to the } \\
\text { pump-and-treat system. }\end{array}$ & $\begin{array}{l}\text { 1. In August } 1998 \text {, design was modified to separate the } \\
\text { influent from the } 100-\mathrm{H} \text { and } 100-\mathrm{D} \text { Areas. This was } \\
\text { performed to minimize waste generation that had } \\
\text { resulted from the gradual increase of technetium-99 } \\
\text { in the } 100 \text {-H Area groundwater. } \\
\text { 2. Modifications to the system in } 1999 \text { included the } \\
\text { addition of an acid injection system to the } 100-\mathrm{H} \\
\text { Area transfer tank. This modification was designed } \\
\text { to adjust pH of groundwater (from } 8 \text { to } 7.0 \text { ), which } \\
\text { prevents the buildup of hard water deposits on the } \\
\text { inside of the treatment system. } \\
\text { An additional extraction well (199-H4-65) was } \\
\text { installed in the } 100 \text { - } \mathrm{H} \text { Area during CY } 1999 \text { to } \\
\text { improve capture of the system. The well was } \\
\text { operational throughout CY } 2000 \text {. } \\
\text { The extraction flow rate averaged } 663.7 \mathrm{~L} / \mathrm{min} \text { in } \\
\text { 2000. The maximum processing flow-rate of the } \\
\text { treatment system is } 757 \mathrm{~L} / \text { min. Therefore the system } \\
\text { is operating at about } 88 \% \text { of its maximum flow rate } \\
\text { capacity. }\end{array}$ \\
\hline $\begin{array}{l}\text { The system shall be designed so if one or } \\
\text { several of the wells are down, the remainder } \\
\text { of the system can continue operating. }\end{array}$ & $\begin{array}{l}\text { 1. Extraction wells are on separate conveyance laterals } \\
\text { allowing for independent operation. } \\
\text { 2. There are two 4-in.-diameter, } 2.5 \text {-mi transfer lines } \\
\text { between the } 100-\mathrm{D} \text { and } 100 \text {-H Arcas, allowing for } \\
\text { system redundancy. }\end{array}$ \\
\hline $\begin{array}{l}\text { Wastes generated during the remedial action, } \\
\text { disposed principally at the ERDF or at other } \\
\text { onsite or offsite facilities, as appropriate. }\end{array}$ & $\begin{array}{l}\text { After the August } 1998 \text { design change, spent IX resin from } \\
\text { the } 100-D \text { Area groundwater treatment system } \\
\text { (nonregulated) was shipped offsite for regeneration, and } \\
\text { spent IX resin from the } 100-\mathrm{H} \text { Area system (regulated) } \\
\text { was shipped to the ERDF. }\end{array}$ \\
\hline $\begin{array}{l}\text { The extraction and treatment system shall } \\
\text { run on an essentially continuous basis so } \\
\text { resin changes and maintenance can be } \\
\text { performed with minimal impact to system } \\
\text { operation. }\end{array}$ & $\begin{array}{l}\text { Overall system availability for the reporting period } \\
\text { exceeded } 97 \% \text {. System availability is a ratio of actual } \\
\text { time the system is online to the time available for } \\
\text { operation. It includes scheduled and unscheduled } \\
\text { maintenance, system modifications, and outages } \\
\text { associated with weather, power loss, and other acts of } \\
\text { nature. This is an increase from } 1998(82 \%) \text { and } 1999 \\
(89 \%) \text {. }\end{array}$ \\
\hline $\begin{array}{l}\text { The system should be winterized so the } \\
\text { winter weather conditions do not cause } \\
\text { extended shutdowns. }\end{array}$ & $\begin{array}{l}\text { 1. Buildings are insulated and heated. } \\
\text { 2. High-density polyethylene conveyance piping not } \\
\text { susceptible to freeze damage while in operations. }\end{array}$ \\
\hline
\end{tabular}

ERDF $=$ Environmental Restoration Disposal Facility 
Table 2-19. Aquifer Performance Summary for the 100-HR-3 Pump-and-Treat System. (2 Pages)

\begin{tabular}{|c|c|}
\hline Aquifer Performance Criteria & 100-HR-3 OU Result \\
\hline $\begin{array}{l}\text { Verify system and aquifer effectiveness and } \\
\text { efficiency. }\end{array}$ & $\begin{array}{l}\text { 1. Water and river levels were monitored continuously } \\
\text { during the period. } \\
\text { 2. Based on the numerical modeling, the capture of the } \\
\text { targeted aquifer is an estimated } 84 \% \text { at the } 100-\mathrm{D} \\
\text { Area and an estimated } 94 \% \text { at the } 100-\mathrm{H} \text { Area. } \\
\text { 3. Overall, chromiun concentrations in the compliance } \\
\text { wells exceed the action level concentration of } \\
22 \mu \mathrm{g} / \mathrm{L} \text {. The determination of the effectiveness of } \\
\text { the pump-and-treat system on the aquifer has been } \\
\text { masked to some degree by the influences (e.g., high- } \\
\text { water mixing in initial samples collected from } \\
\text { compliance wells) of the Columbia River on the } \\
\text { aquifer system and/or other factors. Based on the } \\
\text { available data, the chromium concentration in the } \\
\text { near-river wells has increased from } 1999 \text { to } 2000 \text {. } \\
\text { 4. The removal efficiency of the treatment system } \\
\text { exceeded } 93 \% \text {. }\end{array}$ \\
\hline $\begin{array}{l}\text { Establish baseline aquifer conditions three } \\
\text { to four times prior to full-time operations. }\end{array}$ & $\begin{array}{l}\text { Monthly sampling was performed as specified in the } \\
\text { RDR/RAWP (DOE-RL 1996b). }\end{array}$ \\
\hline Sampling at multiple depth intervals. & $\begin{array}{l}\text { Multi-level sampling at well 199-D8-70 indicates } \\
\text { essentially no distinct difference in chromium } \\
\text { concentrations at different depths. }\end{array}$ \\
\hline $\begin{array}{l}\text { Sampling conducted when dilution by river } \\
\text { water is minimal. }\end{array}$ & $\begin{array}{l}\text { 1. The chromium plumes presented in this report are } \\
\text { based on a sampling event that occurred in the fall, } \\
\text { when the river was low and dilution was minimal. } \\
\text { 2. Sampling was conducted in the fall, and Columbia } \\
\text { River water levels were lower in } 2000 \text { than } 1999 \text {. As } \\
\text { a result, chromium concentrations increased in } 2000 \\
\text { compared to } 1999 \text {. }\end{array}$ \\
\hline $\begin{array}{l}\text { The analyte list shall include hexavalent } \\
\text { chromium, conductivity, and infrequent- } \\
\text { basis co-contaminants. }\end{array}$ & $\begin{array}{l}\text { 1. For sampling events that were conducted throughout } \\
\text { the period, the analyte list included the analytes } \\
\text { requested in the RDR/RAWP (DOE-RL 1996b). } \\
\text { 2. In addition, the results of the co-contaminant } \\
\text { monitoring were used to modify system operations } \\
\text { during the period. For example, technetium-99, a } \\
\text { radionuclide co-contaminant in the 100-H Area, was } \\
\text { detected in August 1998, and the treatment system } \\
\text { was divided into separate 100-H and 100-D Area } \\
\text { groundwater influent flow, thereby minimizing } \\
\text { dangerous waste generation. } \\
\text { 3. The automated chromium analyzer has been } \\
\text { installed, tested, and evaluated. Since samples are } \\
\text { required only one time per week, the analyzer should } \\
\text { not replace the standard Hach kit analysis due to } \\
\text { routine maintenance costs. }\end{array}$ \\
\hline
\end{tabular}


Table 2-19. Aquifer Performance Summary for the 100-HR-3 Pump-and-Treat System. (2 Pages)

\begin{tabular}{|l|l|}
\hline \multicolumn{1}{|c|}{ Aquifer Performance Criteria } & \multicolumn{1}{c|}{ 100-HR-3 OU Result } \\
\hline $\begin{array}{l}\text { After treatment, water will be injected into } \\
\text { the upper aquifer using injection wells } \\
\text { located upgradient of the existing plume. }\end{array}$ & $\begin{array}{l}\text { There are currently three injection wells located in the } \\
\text { 100-H Area upgradient of the extraction wells. }\end{array}$ \\
\hline
\end{tabular}

RDR/RAWP $=$ remedial design report/remedial action work plan 


\subsection{0-KR-4 PUMP-AND-TREAT SYSTEM}

The 100-KR-4 pump-and-treat facility is located along the Columbia River, several miles southwest of the 100-HR-3 OU. The 100-KR-4 OU is one of three OUs associated with the $100-\mathrm{K}$ Area and includes the groundwater underlying the 100-KR-1 and 100-KR-2 source OUs. The 100-KR-4 treatment system and injection/extraction well field are located northeast of the $\mathrm{KE}$ Reactor and adjacent to the 116-K-2 mile-long disposal trench, as shown in Figure 3-1. A map of well, seep, and aquifer tube locations in the 100-K Area can be found in Figure 3-2.

The $100-\mathrm{KR}-4$ OU is similar to the $100-\mathrm{HR}-3$ OU in that the key COC is hexavalent chromium. Co-contaminants in the 100-KR-4 OU include tritium, strontium-90, carbon-14, and nitrate. This section provides the annual performance report for the 100-KR-4 OU for the reporting period of January 1,2000, through December 31,2000. The section is arranged in five subsections. Section 3.1 presents the history of operations, references applicable documents, and briefly discusses other relevant activities. Section 3.2 summarizes the treatment system performance, system operations, extraction well operations, and operational sampling. An evaluation of the aquifer response including hydraulic monitoring, numerical modeling, and contaminant monitoring is discussed in Section 3.3. Section 3.4 presents conclusions on progress toward achieving each RAO and the performance criteria. Section 3.5 summarizes the issues that need further evaluation and Section 3.6 provides recommendations to change/enhance the 100-KR-4 OU pump-and-treat system. Cost information is presented separately in Section 5.0.

\subsection{HISTORY OF OPERATIONS}

In July 1994, the Limited Field Investigation Report for the 100-KR-4 Operable Unit (DOE-RL 1994), including the qualitative risk assessment, was completed. The report concluded that an interim remedial measure (IRM) was not warranted based on human health risk, but an IRM could be justified for ecological concerns related to chromium. In October 1995, the 100-KR-4 Operable Unit Focused Feasibility Study (DOE-RL 1995b) and proposed plan (DOE-RL 1995e) were completed. The proposed plan recommended a pump-and-treat IRM to mitigate chromium migration into the Columbia River.

In April 1996, an interim remedial action ROD (EPA 1996) was issued for the pump-and-treat system in the 100-KR-4 OU. The ROD specified installation of a pump-and-treat system in the 100-HR-3 OU and 100-KR-4 OU to intercept portions of the chromium plumes that impact the Columbia River. Full-time operation of the treatment system was initiated on October 1, 1997.

Detailed site characterization and background information on the OU and the pump-and-treat activity is provided in the limited field investigation report (DOE-RL 1994) and the feasibility study (DOE-RL 1995b). Further information on the pump-and-treat system design and operation can be found in the Remedial Design Report and Remedial Action Work Plan for the 100-HR-3 and 100-KR-4 Groundwater Operable Units' Interim Action (DOE-RL 1996b), and the 100-HR-3 and 100-KR-4 Operable Units' Interim Action Performance Evaluation Report 
(DOE-RL 1998). Groundwater monitoring requirements are described in the Interim Action Monitoring Plan for the 100-HR-3 and 100-KR-4 Operable Units (DOE-RL 1997a). Other background/current information is available in the Hanford Site Groundwater Monitoring for Fiscal Year 2000 (PNNL 2000a).

Other relevant activities that were completed in CY 2000 for the 100-KR-4 OU include the following:

- Aquifer tube sampling was conducted along the low-water shoreline of the 100-K Area during the fall of 2000 . The results of this effort will be reported in a separate document to be released in FY 2001.

- The EPA initiated a review of remedial actions at the Hanford Site, including the 100-KR-4 pump-and-treat system, in accordance with CERCLA requirements.

\subsection{0-KR-4 TREATMENT SYSTEM PERFORMANCE}

This section describes the 100-KR-4 pump-and-treat system operations and sampling that occurred January 1, 2000, through December 31, 2000. Specific details include system availability, changes to the system configuration, mass of contaminants removed during operations, contaminant removal efficiencies, quantity and quality of extracted and disposed groundwater, waste generation, and contaminant trends.

\subsubsection{System Operation}

Groundwater is withdrawn from the aquifer at six extraction wells in the $100-\mathrm{K}$ Area (119-K-113A, 199-K-115A, 199-K-116A, 199-K-119A, 199-K-120A, and 199-K-125A), which are located between the river shoreline and the $116-\mathrm{K}-2$ liquid effluent disposal trench (source unit). The extracted groundwater is pumped into an influent storage tank. Feed pumps are used to pump contaminated water from the influent storage tank, through an IX treatment system, and into the effluent storage tank. Treated water is pumped from the effluent storage tank to four injection wells (199-K-121A, 199-K-122A, 199-K-123A, and 199-K-124A), which are located upgradient of the contaminant plume in the $100-\mathrm{KR}-4 \mathrm{OU}$. A schematic of the treatment system, extraction wells, and injection wells is included in Figure 3-3.

The following is a summary of the $100-\mathrm{KR}-4$ pump-and-treat operations.

Total amount of groundwater treated (since October 1997 startup):

Total amount of groundwater treated during CY 2000:

908.0 million $\mathrm{L}$ 286.7 million $\mathrm{L}$

Total amount of hexavalent chromium removed (since October 1997 startup): $113.9 \mathrm{~kg}$

Total amount of hexavalent chromium removed in CY 2000:

Table 3-1 provides a comparison of CY 2000 operational statistics to CY 1999 statistics. As shown in Table 3-2, the average hexavalent chromium concentration in the 100-KR-4 influent 
was approximately $123 \mu \mathrm{g} / \mathrm{L}$, with a maximum of $136 \mu \mathrm{g} / \mathrm{L}$. These numbers are down slightly from the CY 1999 average of $132 \mu \mathrm{g} / \mathrm{L}$ with a maximum of $157 \mu \mathrm{g} / \mathrm{L}$ (DOE-RL 2000a). The average effluent hexavalent chromium concentration was approximately $6 \mu \mathrm{g} / \mathrm{L}$. Trend plots of the influent and effluent concentrations can be found in Figure 3-4. At times during the year, hexavalent chromium concentrations in the effluent exceeded the RAO of $22 \mu \mathrm{g} / \mathrm{L}$. These occurrences of abnormally high concentrations were due to improper vessel realignment after vessel changeouts. CY 2000 removal efficiency exceeded 95\% (Table 3-1), which is up from CY 1999 (Figure 3-5).

An IX process is used to remove hexavalent chromium from extracted groundwater. Two separate IX skids (consisting of four IX vessels in a series), each with $379-\mathrm{L} / \mathrm{min}$ capacity, are housed in the treatment building. The IX skids are referred to as K-IX-A and K-IX-B. The trcatment system is sized for a maximum processing rate of $758 \mathrm{~L} / \mathrm{min}$. The average treatment system flow rate was $600 \mathrm{~L} / \mathrm{min}$, which is $79 \%$ of system capacity. During 2000, a total of 26 spent IX vessels were changed out (Table 3-1), which equates to $59.8 \mathrm{~m}^{3}$ of spent resin. The frequency of the changeouts per vessel averaged 112 days. After resin is spent, it is shipped to an off site for regeneration and reuse. Before it is shipped, the resin is analyzed to determine if it meets shipping guidelines. A problem that occurred in CY 2000 is that resin could not be shipped off site because uranium concentrations exceeded shipping criteria. The main reason for this is because resin was left on line long enough to accumulate the concentration. Therefore, the frequency in between resin changeouts was increased and the number of changeouts increased from the previous year.

Overall system availability from January 1, 2000, through December 31, 2000, exceeded $98 \%$ (time on-line/(total hours during the year-scheduled outages). The on-line availability was slightly less at $95.6 \%$ (time on-line/total hours during the year). Significant outages are detailed in Figure 3-6.

Process systems operations monitor the levels of hexavalent chromium by weekly sampling of extraction wells and influent and effluent ports. The operators then analyze these samples for hexavalent chromium. Field technicians collect quarterly samples from the extraction wells and influent and effluent ports, analyze for hexavalent chromium, and compare the results to the operator's results to provide quality control. The technicians additionally collect and analyze duplicates to provide precision to their results. The duplicate results are displayed in Table 3-3. The RPD for the duplicates ranged from -1.0 to 2.5 .

The operator's results were compared to the technician's results by calculating the RPDs for a sample pair. However, because the sample pairs were not collected on the same day, the quarterly sample from a well or sample port was paired with the closest weekly sample from the same location. The RPD was calculated by subtracting the operator's result from the technician's result and dividing by the average of the two sample results. The RPDs for the sample pairs described above are included in Table 3-4.

The RPDs range from $-17.8 \%$ to $+5.0 \%$. The average RPD value for the data was $2.3 \%$. The average of the measurements and the RPDs for the measurements are shown graphically in Figure 3-7. 
Additionally, some quarterly samples were split and analyzed by an offsite laboratory to assess the analytical precision for samples collected for chromium analysis using the field Hach hexavalent chromium method compared to EPA Method 7196 (EPA 1986). The field analysis was compared to the laboratory split by calculating the RPD for the sample pair. The RPD was calculated by subtracting the field result from the laboratory result and dividing by the average of the two sample results. As shown in Table 3-5, the $100-\mathrm{KR}-4$ split RPDs ranged from $-8.1 \%$ to $7.1 \%$; the average RPD of the splits was $-0.8 \%$.

\subsubsection{Operations Wells}

Six extraction wells have been operating since the initiation of operations in October 1997; however, well 199-K-125A replaced well 199-K-118A because heavy silt buildup in well 119-K-118A made it unusable. Sample data collected from these wells were used for monitoring process operations and evaluating the aquifer response to remediation activities. The six extraction wells are as follows:

- 199-K-119A

- 199-K-120A

- 199-K-113A

- 199-K-115A

- 199-K-116A

- 199-K-125A.

The average groundwater extraction rate for the six well extraction wells was approximately $600 \mathrm{~L} / \mathrm{min}$. Production rates for the extraction wells in the system ranged from $88 \mathrm{~L} / \mathrm{min}$ to $123 \mathrm{~L} / \mathrm{min}$. Four injection wells (199-K-121A, 199-K-122A, 199-K-123A, and 199-K-124A) continue to operate upgradient of the extraction wells.

\subsubsection{Operational Monitoring/Sampling}

Water levels, flow rates, pressures, component status (i.e., on or off), and other process information are monitored and recorded by the programmable logic controller and operator interface computer. An automatic shutdown is initiated if operational parameters fall outside of normal operating ranges, which protects the system if a component failure occurs. The operational data are recorded by the operator interface computer and are automatically downloaded on a regular basis. The data are then exported to the $100-\mathrm{HR}-3 / 100-\mathrm{KR}-4$ project-specific database, which is a Microsoft ${ }^{\circledR}$ Access database maintained on the Bechtel local area network in Richland, Washington. Most of the chromium concentration data from the project-specific database are also stored in the HEIS database.

In addition to system parameters recorded by the operator interface computer, operators sample process water to monitor the performance of the pump-and-treat system and to ensure that the system is effectively meeting the requirements of the interim remedial action ROD (EPA 1996). Operational samples are taken from four categories of sources for the pump-and-treat system:

${ }^{\circledR}$ Microsoft is a registered trademark of the Microsoft Corporation, Redmond, Washington. 
extraction wells, combined influent to the treatment system, combined effluent from the treatment system, and after each of the IX vessels in use. The data are recorded in the database to address system performance criteria such as determining system downtime, availability, and efficiency. The specific sample points are identified in Figure 3-3 as a sample collection point (SC) or an alternate sample collection point (HP).

Water from each sample point is sampled and field analyzed during manned operations to monitor hexavalent chromium levels. Field screening has been used to reduce operational costs and to provide process data to operators in real-time. Influent and effluent are sampled and analyzed offsite quarterly for hexavalent chromium. For semi-annual samples, conductivity and co-contaminants (strontium- 90 [measured as total beta radiostrontium] and tritium) arc analyzed in addition to hexavalent chromium. This satisfies the performance criteria analytical requirements for sampling of the treatment system.

\subsubsection{Hexavalent Chromium in Extraction Wells}

The chromium results for CY 1997 through CY 2000 are shown in Table 3-2. The CY 2000 results can be summarized as follows:

- The average of four of the six extraction wells was characterized by stable concentrations in CY 2000 relative to CY 1999. Wells 199-K-113A, 199-K-115A, 199-K-116A, and $199-\mathrm{K}-120 \mathrm{~A}$ had average concentrations of $80 \mu \mathrm{g} / \mathrm{L}, 128 \mu \mathrm{g} / \mathrm{L}, 179 \mu \mathrm{g} / \mathrm{L}$, and $97 \mu \mathrm{g} / \mathrm{L}$, respectively.

- Extraction wells $199-\mathrm{K}-119 \mathrm{~A}$ and $199-\mathrm{K}-125 \mathrm{~A}$ were both characterized by decreasing hexavalent chromium concentrations in CY 2000 compared to CY 1999 concentrations. Average concentrations dropped from $146 \mu \mathrm{g} / \mathrm{L}$ to $111 \mu \mathrm{g} / \mathrm{L}$ in wcll $199-\mathrm{K}-119 \mathrm{~A}$ and from $157 \mu \mathrm{g} / \mathrm{L}$ to $116 \mu \mathrm{g} / \mathrm{L}$ in well $199-\mathrm{K}-125 \mathrm{~A}$.

3.2.4.1 Co-Contaminants in Extraction Wells and Effluent. Average co-contaminant data for the extraction wells can be found in Table 3-6. The CY 2000 results can be summarized as follows:

- Tritium: Tritium activity was above the MCL in one well, $199-\mathrm{K}-120 \mathrm{~A}$, at $69,300 \mathrm{pCi} / \mathrm{L}$ $(+/-7,000)$. However, tritium activity was stable in wells $199-\mathrm{K}-120 \mathrm{~A}$ and $199-\mathrm{K}-115 \mathrm{~A}$. Wells $199-\mathrm{K}-119 \mathrm{~A}$ and $199-\mathrm{K}-125 \mathrm{~A}$ were characterized by increasing tritium activity at 846 $\mathrm{pCi} / \mathrm{L}(+/-160)$ and $3,525 \mathrm{pCi} / \mathrm{L}(+/-410)$, respectively. Well $199-\mathrm{K}-116 \mathrm{~A}$ tritium activity has been stable since a large decrease in CY 1998. Well 199-K-113A was not sampled for tritium during CY 2000.

- Total beta radiostrontium: Total beta radiostrontium activities were above the MCL in one well, 199-K-115A, at $12 \mathrm{pCi} / \mathrm{L}$. However, activities were stable in well 199-K-115A and were also stable in wells $199-\mathrm{K}-116 \mathrm{~A}$ and $199-\mathrm{K}-120 \mathrm{~A}$. Total beta radiostrontium remains undetected in wells 199-K-119A and 199-K-125A. Well 199-K-113A was not sampled in CY 2000, but had been above the MCL for total beta radiostrontium for the previous 2 years. 
Contaminant trend plots for the 100-KR-4 extraction wells can be found in Appendix G. In summary, operational sampling in the 100-KR-4 extraction wells in CY 2000 showed no dramatic changes in contaminant concentrations.

The CY 2000 tritium results for the effluent was $12,600 \mathrm{pCi} / \mathrm{L}$, which is below the MCL of $20,000 \mathrm{pCi} / \mathrm{L}$. The tritium trend is stable compared to previous results. The total beta radiostrontium activities results were $4.98 \mathrm{pCi} / \mathrm{L}$, which is below the $\mathrm{MCL}$. The trends are stable compared to previous results.

\subsection{AQUIFER RESPONSE IN THE 100-K AREA}

Water level, chromium concentration, and other groundwater chemistry measurements were collected or measured at wells located in the 100-K Area as part of CERCLA and interim remedial action performance monitoring. Monitoring requirements specific to the interim remedial action are listed in DOE-RL (1996b) and DOE-RL (1997a). The monitoring program collects data to determine the aquifer hydraulic and hydrochemical response to pump-and-treat operations. Additional groundwater monitoring and evaluation are performed under operational and sitewide surveillance requirements imposed by DOE Order 5400.1 Environmental Protection (DOE-RL 2000b). A description of groundwater monitoring associated with all projects on the Hanford Site is available in the Integrated Monitoring Plan for the Hanford Groundwater Project (PNNL 2000b).

Section 3.3.1 provides details of the measured hydraulic responses, Section 3.3.2 provides a discussion of the hydraulic capture and containment exerted by the pump-and-treat system, and Section 3.3.3 discusses the measured chemical responses to the pump-and-treat system.

\subsubsection{Hydraulic Monitoring}

Some 100-K Area extraction wells are located near the Columbia River. Evaluating the impact of the pump-and-treat system on the aquifer near the river requires distinguishing water-level changes caused by the extraction wells from those caused by changes in river stage. To determine the hydraulic impacts of the pump-and-treat system near the river, the same method of analyzing the hourly water-level data described in Section 2.3.1 was used.

At the 100-K Area, the pump-and-treat system shut down on December 30, 1999, and remained off until January 14, 2000, a sufficient amount of time for the water table to recover. The analysis compared data collected during the shutdown versus periods of steady pumping. The difference in the correlation lines was used to determine the drawdown and buildup caused by the pump-and-treat system. For the wells located too far inland to exhibit daily fluctuations in their hydrographs, the drawdown and buildup were determined by extrapolating water-level trends established during the shutdown period through the period of operation.

3.3.1.1 Extraction and Injection Wells. The production characteristics of the six extraction wells are widely variable. In general, the extraction wells operated at flow rates between $95 \mathrm{~L} / \mathrm{min}$ and $174 \mathrm{~L} / \mathrm{min}$ during the year. Changes in the flow rates from the design quantity of 
$95 \mathrm{~L} / \mathrm{min}$ were made on the basis of recommendations in previous performance evaluation and annual summary reports (DOE-RL 1998, 1999a) and to compensate for temporarily inactive wells. Drawdown measurements and flow rates represent values determined for the specific time period during which the analysis was performed. The extraction wells operated at or near the design flow rate of $95 \mathrm{~L} /$ min during the analysis period. Well $199-\mathrm{K}-116 \mathrm{~A}$ is the most productive well, producing a $97-\mathrm{L} / \mathrm{min}$ flow rate, with approximately $0.21 \mathrm{~m}$ of drawdown. Drawdown measured in the other extraction wells at the nominal flow rate of $95 \mathrm{~L} / \mathrm{min}$ was (in order from south to north) $0.40 \mathrm{~m}$ in well $199-\mathrm{K}-120 \mathrm{~A}, 1.75 \mathrm{~m}$ in well $199-\mathrm{K}-119 \mathrm{~A}, 1.39 \mathrm{~m}$ in well 199-K-125A, $1.07 \mathrm{~m}$ in well $199-\mathrm{K}-115 \mathrm{~A}$, and $1.51 \mathrm{~m}$ in well 199-K-113A. The waterlevel data and correlation lines used to calculate the drawdown in the extraction wells are contained in Appendix $\mathrm{C}$, and the results are summarized in Table 3-7.

Recovery in the four injcction wclls was measured using the data collected during the shutdown beginning on December 30, 1999. Flow-rate and water-level data collected during continuous operation from December 26 through December 28, 1999, were compared to the average water level in the four injection wells after the water level in the wells recovered and stabilized during the shutdown. The average injection rates for wells 199-K-121A, 199-K-122A, 199-K-123A, and $199-\mathrm{K}-124 \mathrm{~A}$ were $101 \mathrm{~L} / \mathrm{min}, 186 \mathrm{~L} / \mathrm{min}, 151 \mathrm{~L} / \mathrm{min}$, and $110 \mathrm{~L} / \mathrm{min}$, respectively. Buildup in the wells measured $5.01 \mathrm{~m}, 2.26 \mathrm{~m}, 5.02 \mathrm{~m}$, and $6.49 \mathrm{~m}$, respectively. Flow rates in extraction and injection wells represent operating averages and do not account for unequal operating times. The water-level data used to calculate the buildup in the injection wells are contained in Appendix C, and the results are summarized in Table 3-7.

3.3.1.2 Monitoring Wells. Eight monitoring wells are currently equipped with pressure transducers and data loggers that record hourly water-level measurements to help assess the hydraulic capture and containment of the extraction wells (Appendix C). Drawdown was $0.04 \mathrm{~m}$ in well 199-K-112A and $0.05 \mathrm{~m}$ in well $199-\mathrm{K}-18$, which are the $100-\mathrm{K}$ Area compliance wells located farthest to the north and south, respectively. Drawdown was $0.04 \mathrm{~m}$ in well $199-\mathrm{K}-114 \mathrm{~A}, 0.11 \mathrm{~m}$ in well $199-\mathrm{K}-20$, and $0.15 \mathrm{~m}$ in well $199-\mathrm{K}-117 \mathrm{~A}$, which are the three other compliance wells located in the area. Drawdown was $0.17 \mathrm{~m}$ in well $199-\mathrm{K}-21$, which is located between extraction wells 199-K-116A, 199-K-125A, and 199-K-115A. Drawdown was $0.06 \mathrm{~m}$ in well $199-\mathrm{K}-37$ and $0.21 \mathrm{~m}$ in well $199-\mathrm{K}-22$, which are located near the $116-\mathrm{K}-2$ Trench and upgradient from wells 199-K-113A and 199-K-115A. The water-level data and correlation lines used to calculate the drawdown in the monitoring wells are contained in Appendix C, and the results are summarized in Table 3-7.

\subsubsection{Numerical Modeling}

A steady-state numerical groundwater model (Micro-Fem) was used to estimate and evaluate the hydraulic capture of the pump-and-treat system in the 100-K Area. The model development process used to construct the $100-\mathrm{K}$ Area groundwater model and the modeling objectives, limitations, and assumptions are described in detail in Appendix $\mathrm{K}$.

Flow lines terminating at the extraction wells in Figures 3-8 and 3-9 show the area of the aquifer through which each extraction well removes groundwater and the chromium carried in the water. The total area encompassed by the flow lines terminating at each extraction well represents the 
capture zone of that extraction well. Flow lines terminating at the river (shown in Figures 3-9 and 3-10) indicate areas where the groundwater passes uncaptured by the extraction wells and discharges into the river. Also shown in the figures is the plume distribution described in Section 3.3.3.1. A comparison of the modeled water levels to the measured water levels measured in November is included in Table 3-7.

Hydraulic capture extends northward to a point almost halfway between wells $199-\mathrm{K}-113 \mathrm{~A}$ and 199-K-112A (the northernmost compliance well). Most of the water between wells 199-K-113A and $199-\mathrm{K}-116 \mathrm{~A}$ is captured, but some of the groundwater appears to pass uncaptured and discharges into the river. Because of the high transmissivity around well 199-K-116A, the capture zone resulting from pumping in that well is smaller compared to the capture zones surrounding the other extraction wells. Groundwater on either side of this well still appears to travel uncaptured to the river, even with the addition of extraction well 199-K-125A. The flow lines indicate that some groundwater may pass uncaptured between wells $199-\mathrm{K}-120 \mathrm{~A}$ and 199-K-119A. The high transmissivity around well 199-K-120A and the proximity of this well to the injection well field result in a narrow capture zone around this well.

To quantitatively assess the relative effectiveness of hydraulic capture, a series of 50 flow lines was added to the capture analysis (Figure 3-9). The flow lines indicate where a particle of water travels in the aquifer and whether the water is captured by the extraction wells or discharged into the river. The series was placed upgradient of the $116-\mathrm{K}-2$ Trench, within the area originally defined as the target area of the pump-and-treat system (Figure 3-6 in DOE-RL 1996b). The extraction wells capture 38 of the 50 flow lines, suggesting that the pump-and-treat system currently captures a similar portion of the groundwater flowing through approximately $76 \%$ of the target (remediation) area. Most of the uncaptured groundwater that discharges into the river in the target area passes between wells $199-\mathrm{K}-115 \mathrm{~A}$ and 199-K-125A (where the transmissivity is greatest) and wells 199-K-119A and 199-K-120A. Wells 199-K-119A and 199-K-120A are located near a culturally sensitive area, and the placement of those wells was strongly influenced by cultural concerns.

To address groundwater containing greater than $50 \mu \mathrm{g} / \mathrm{L}$ passing uncaptured around well 199-K-112A, activity during CY 2000 included converting the well from a compliance well to an extraction well. Pumping data collected during development of the well indicate that the well can sustain a flow rate of $95 \mathrm{~L} / \mathrm{min}$. Adding well $199-\mathrm{K}-112 \mathrm{~A}$ to the extraction well network in the model increased the capture zone north of the 116-K-2 Trench and results in capture of 40 of the 50 flow lines, or the capture of groundwater flowing through $80 \%$ of the original target area. Much of the groundwater captured by well 199-K-112A is located outside the original target area, but appears to have a chromium concentration greater than $50 \mu \mathrm{g} / \mathrm{L}$. The plume north of the trench was not well defined because no monitoring wells, except well 199-K-37, existed north of the trench during the pump-and-treat system design phase. To optimize capture and containment within current design constraints and with the addition of well 199-K-112A to the pump-and-treat system, the flow in well $199-\mathrm{K}-116 \mathrm{~A}$ was increased to $170 \mathrm{~L} / \mathrm{min}$ in the model. The model results indicated capture of 43 of the 50 flow lines, or the capture of groundwater flowing through $86 \%$ of the original target area (Figure 3-10). The model results indicated that in this case, most of the uncaptured water would pass between wells $199-\mathrm{K}-119 \mathrm{~A}$ and 199-K-120A. 
Hydraulic capture between wells $199-\mathrm{K}-119 \mathrm{~A}$ and $199-\mathrm{K}-120 \mathrm{~A}$ is incomplete. Upgrades to increase the hydraulic capture beyond the optimized levels of the current system requires additional treatment capacity, larger volume pumps, and additional extraction and injection wells. Planning for these upgrades are currently under way in response to findings of the CERCLA 5-year review by the EPA.

\subsubsection{Contaminant Monitoring}

This section summarizes and interprets analytical results obtained from groundwater wells included in the interim remedial action and OU monitoring programs supporting the 100-KR-4 pump-and-treat system and OU in the $100-\mathrm{K}$ Area. The remedial design report/remedial action work plan (DOE-RL 1996b) provides details on the groundwater monitoring for the interim action. Data are stored in the HEIS database and/or the project-specific database.

The principal COC in the $100-\mathrm{K}$ Area is chromium. Co-contaminants are tritium, strontium-90, carbon-14, and nitrate. Section 3.3.3.1 discusses the results of chromium monitoring, and Section 3.3.3.2 discusses the results of co-contaminant monitoring. Locations of the wells used for monitoring are shown in Figure 3-2. Chromium data and specific conductance data for the $100-\mathrm{K}$ Area wells are provided in Appendix H. Conductivity data are useful in evaluating effects of river water/groundwater mixing in chromium concentrations.

3.3.3.1 Chromium Monitoring Results. Chromium is monitored throughout the 100-K Area in compliance, extraction, and monitoring wells, and at sample tube locations along the Columbia River. Monitoring is also performed at two riverbank seepage located along the steep slopes adjacent to the river. The numbers of groundwater monitoring locations and sampling frequencies in the 100-K Area are identified in Table 3-8. Additional groundwater monitoring information for 2000 is provided in the Interim Action Monitoring Plan for the 100-HR-3 and 100-KR-4 Operable Units (DOE-RL 1997a). Construction details and the use of each well in the 100-K Area network are presented in Table 3-9.

Because of site waste control issues that occurred in 2000 , adjustments to the scheduled monitoring program were required. These adjustments involved canceling the March and April monthly compliance monitoring and the April 2000 quarterly OU monitoring event. Additional changes to the planned 2000 monitoring program included the following:

- Compliance well 199-K-112A was converted to an extraction well to improve chromium plume capture.

- Monitoring well $199-\mathrm{K}-126$ was added to the compliance monitoring network to evaluate the effectiveness of the new extraction well 199-K-112A to contain chromium.

The chromium distribution pattern in groundwater in the 100-K Area has remained relatively constant since the baseline chromium plume map was developed in 1995. The highconcentration areas appear to be diminishing. Figure 3-11 presents the 1995 baseline chromium distribution map and successive maps developed for fall 1998, fall 1999, and fall 2000 chromium 